\title{
Ecological Benefits of Watershed-scale Restoration in Two Intensively Mined Cold- and Warm-water Ecosystems
}

\author{
Rebecca Anne Long \\ West Virginia University, ral0018@mix.wvu.edu
}

Follow this and additional works at: https://researchrepository.wvu.edu/etd

Part of the Terrestrial and Aquatic Ecology Commons

\section{Recommended Citation}

Long, Rebecca Anne, "Ecological Benefits of Watershed-scale Restoration in Two Intensively Mined Coldand Warm-water Ecosystems" (2019). Graduate Theses, Dissertations, and Problem Reports. 3799.

https://researchrepository.wvu.edu/etd/3799

This Thesis is protected by copyright and/or related rights. It has been brought to you by the The Research Repository @ WVU with permission from the rights-holder(s). You are free to use this Thesis in any way that is permitted by the copyright and related rights legislation that applies to your use. For other uses you must obtain permission from the rights-holder(s) directly, unless additional rights are indicated by a Creative Commons license in the record and/ or on the work itself. This Thesis has been accepted for inclusion in WVU Graduate Theses, Dissertations, and Problem Reports collection by an authorized administrator of The Research Repository @ WVU. For more information, please contact researchrepository@mail.wvu.edu. 
Ecological benefits of watershed-scale restoration in two intensively mined cold- and warmwater ecosystems

\title{
Rebecca Long
}

\author{
A Thesis submitted to \\ The Davis College of Agriculture, Natural Resources and Design \\ at West Virginia University \\ in partial fulfillment of the requirements \\ for the degree of \\ Master of Science \\ in \\ Wildlife and Fisheries Resources
}

\author{
J. Todd Petty, Ph.D., Chair \\ Eric Merriam, Ph.D. \\ Mike Strager, Ph.D.
}

Wildlife and Fisheries Resource Program

Division of Forestry and Natural Resources

Morgantown, WV

2019

Key words: acid mine drainage (AMD), watershed management, biological communities, water chemistry, fisheries, metacommunity ecology, and watershed restoration 


\begin{abstract}
Ecological benefits of watershed-scale restoration in two intensively mined cold- and warmwater ecosystems

Rebecca Long
\end{abstract}

Stream restoration projects are increasingly common. However, restoration projects that establish measurable goals, have pre- and post-restoration monitoring, and are implemented at the watershed scale are rare. We conducted a long-term (9-year) before-after-control-impact designed assessment of two watershed-scale acid mine drainage (AMD) remediation programs, one in a warm-water ecosystem and one in a cold-water ecosystem in West Virginia, USA. Restoration was strategically designed to recover biodiversity and improve the native fisheries by restoring chemically degraded water quality and re-establishing riverscape connectivity. We used analysis of variance to quantify responses in water chemistry, benthic macroinvertebrate communities, and fish community composition before and after restoration within and among treated and un-treated sites. Assessments within the warm- and cold-water watersheds show significant improvements post-restoration in water quality and macroinvertebrate communities in both watersheds. However, differences in fish community responses indicate that regionally degraded conditions may play a role in the ability of fish communities to recover in restored systems. Fish diversity increased to reference conditions in both watersheds but functional fisheries are not recovering. In the warm-water system, the reference sites do not meet the regional drainage area to species richness relationship whereas the cold-water system has intact reference populations within the watershed. This suggests that successful fishery restoration in degraded watersheds depends on the presence of a regional species pool available to repopulate the targeted watershed. Furthermore, long-term changes in fish communities in the cold-water system indicate that fish populations may have a delayed response to restoration projects. Treated sites within the cold-water watershed had significant improvements in water chemistry and macroinvertebrates from 2008 (i.e., pre-restoration) to 2013 and remained unchanged from 2013 to 2017 . However, fish diversity and brook trout populations in treated streams increased significantly from 2008 to 2013 and continued to increase in 2017. The continued increase in brook trout populations over time suggests that restoration was successful in reestablishing connectivity among restored and previously intact brook trout sub-populations. Consequently, the full benefit of restoration may not yet be realized as fish populations continue to expand. 


\section{Acknowledgements}

I would like to thank my committee, Dr. Todd Petty, Dr. Eric Merriam, and Dr. Mike Strager for their support and willingness to help me become a better scientist. Thank you Dr. Todd Petty for your continued confidence and support throughout my project and for the amazing opportunity to work in your lab on such an interesting project. I would especially like to thank Dr. Eric Merriam for the tremendous amount of support at the beginning of my project when I was feeling especially overwhelmed. The continued support and camaraderie from the Petty lab-Donna Hartman, Brian Gordon, Kevin Eliason, and Josh Ankeny_-significantly improved my time at WVU, and their help both inside and outside of work hours was the main reason this project has been successfully completed. 


\section{Table of Contents}

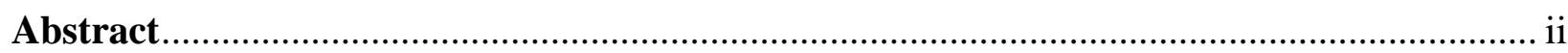

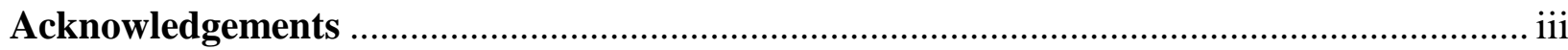

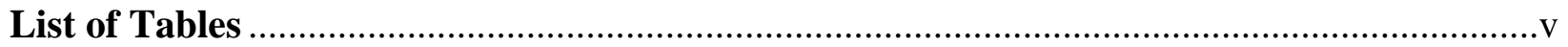

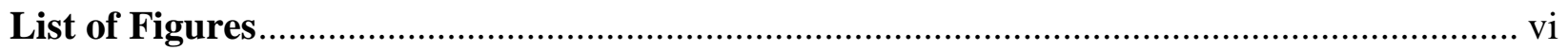

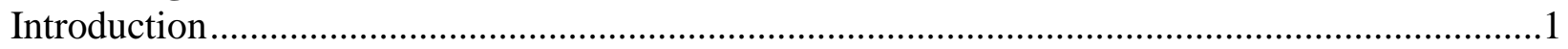

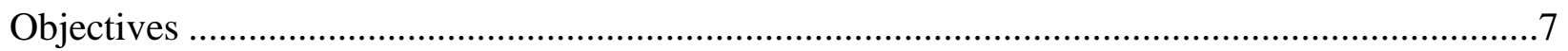

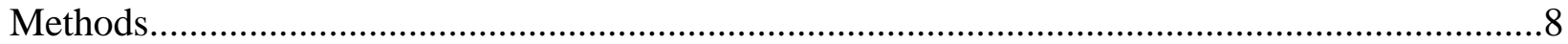

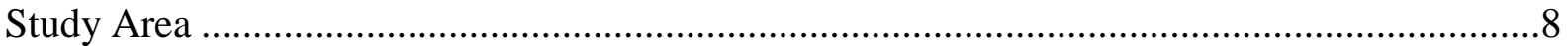

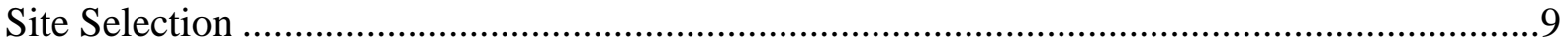

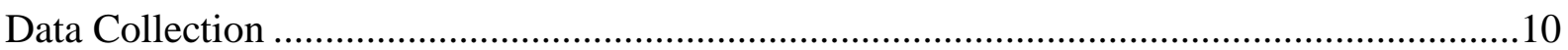

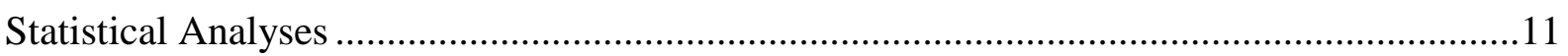

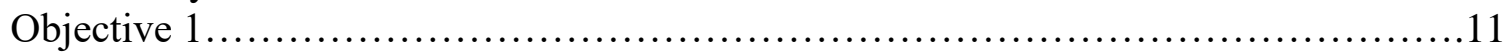

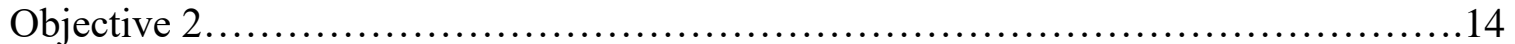

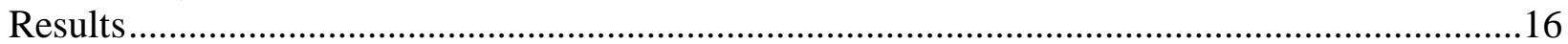

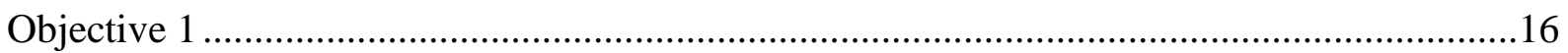

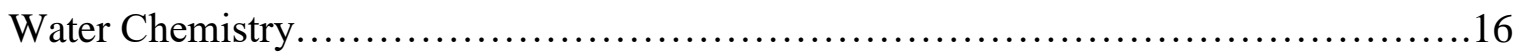

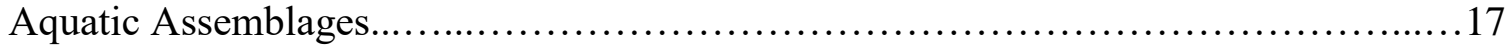

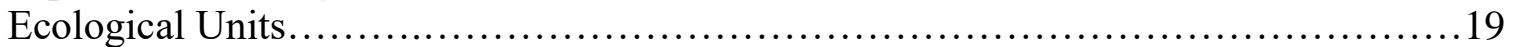

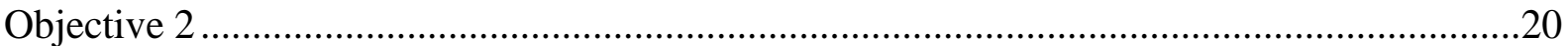

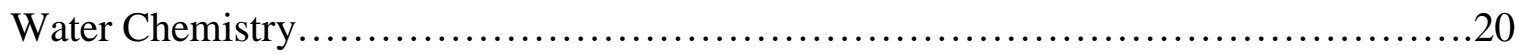

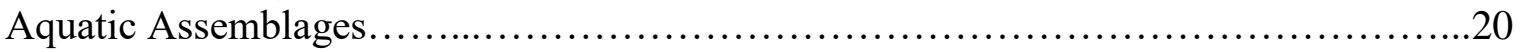

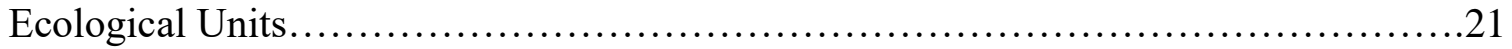

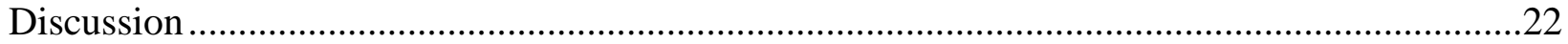

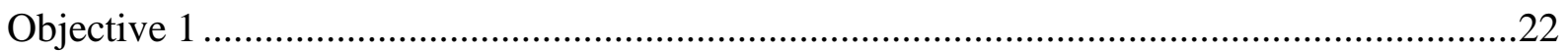

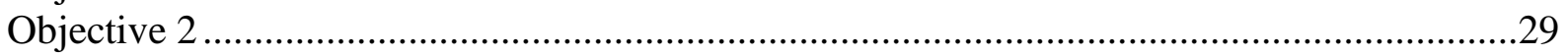

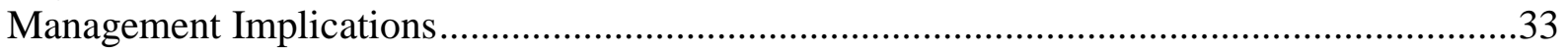

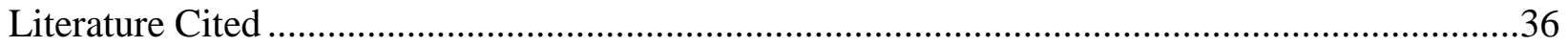

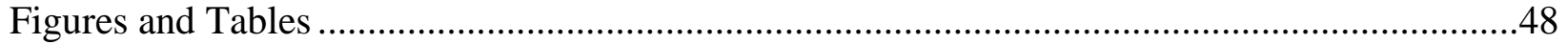

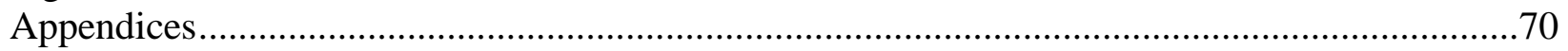




\section{List of Tables}

Table 1. Site names, GPS coordinates, drainage area in $\mathrm{km}^{2}$, and stream type of all sites in the Three Forks Creek watershed

Table 2. Site names, GPS coordinates, drainage area in $\mathrm{km}^{2}$, and stream type of all sites in the Abram Creek watershed.

Table 3. Chemical summary table of water chemistry samples in treated sites pre- (2008) and post-restoration (2017) in Three Forks Creek. Mean concentrations and standard deviations (SD) of each selected chemical parameter among all treated sites is listed

Table 4. Chemical summary table of water chemistry samples in treated sites pre- (2008) and post-restoration (2017) in Abram Creek. Mean concentrations and standard deviations (SD) of each selected chemical parameter among all treated sites is listed.

Table 5. Factor loadings of each chemical parameter analyzed post-restoration (2017) for principal components (PC) 1 and 2 in Three Forks Creek

Table 6. Factor loadings of each chemical parameter analyzed post-restoration (2017) for principal components (PC) 1, 2 and 3 in Abram Creek

Table 7. GLIMPSS scores for each site sampled in Three Forks Creek for the 2008 (prerestoration) and 2017 (post-restoration) sampling years

Table 8. GLIMPSS scores for each site sampled in Abram Creek for the 2008 (pre-restoration), 2013 (post-restoration) and 2017 (post-restoration) sampling years

Table 9. Fish diversity for each site sampled in Three Forks Creek for the 2008 (pre-restoration) and 2017 (post-restoration) sampling years.

Table 10. Fish diversity for each site sampled in Abram Creek for the 2008 (pre-restoration), 2013 (post-restoration) and 2017 (post-restoration) sampling years 


\section{List of Figures}

Figure 1. Map of Three Forks Creek, West Virginia with site locations, site types (i.e. treated, AMD, and reference), and treatment locations

Figure 2. Map of Abram Creek, West Virginia with site locations, site types (i.e. treated, AMD, and reference), and treatment locations

Figure 3. Scatter plots of principal components (PC) 1 and 2 scores for every water chemistry sample in Three Forks Creek and Abram Creek. Points are colored and shaped by site types (red=AMD, green=reference, blue=treated). Vectors show the correlations of each chemical parameter by both direction and degree of correlation (i.e. length of vectors).

Figure 4. Genus-level index of most probable stream status (GLIMPSS) scores pre- (2008) and post-restoration (2017) for the reference and treated sites of Three Fork Creek and Abram Creek. Lowercase letters show significant or non-significant differences between scores of treatment types within each plot. Reference GLIMPSS scores seen for Abram Creek in 2008 were taken from a survey in 2013

Figure 5. Fish diversity scores for the reference and treated sites of Three Forks Creek and Abram Creek pre- (2008) and post-restoration (2017). Lowercase letters show significant or nonsignificant differences between scores of treatment types within each plot

Figure 6. Plot of the relationship between fish species richness and log drainage area for Three Forks Creek (dark solid line), Abram Creek (light solid line) and regional reference conditions (dashed line). Stream types are indicated by shape for AMD, reference, and treated streams and color indicates the watershed the points belong to (i.e. dark grey $=$ Three Forks Creek, light grey= Abram Creek).

Figure 7. Ecological Units in Three Forks Creek for diversity, overall fishery, cold-water fishery, and warm-water fishery. Diversity units in this figure represent macroinvertebrate diversity. Overall fishery units represent a combination of trout and warm-water fisheries....

Figure 8. Ecological Units (EU) in Abram Creek for (A) diversity, (B) brook trout, (C) stocked trout, and (D) overall fishery. Diversity units in this figure represent macroinvertebrate diversity. Overall fishery units represent a combination of native brook trout and stocked trout.

Figure 9. Concentrations of alkalinity ( $\mathrm{CaCO} 3 \mathrm{mg} / \mathrm{L}$ equivalents), aluminum (mg/L), magnesium $(\mathrm{mg} / \mathrm{L})$, and sulfate $(\mathrm{mg} / \mathrm{L})$ in treated sites of Abram Creek in 2008 (pre-restoration), 2013 (postrestoration), and 2017 (post-restoration). Lowercase letters show significant or non-significant differences between scores of treatment types within each plot.

Figure 10. GLIMPSS scores for treated streams and reference streams in Abram Creek for sites sampled in 2008, 2013, and 2014. Lowercase letters show significant or non-significant differences between scores of treatment types.

Figure 11. Shannon diversity of fish communities in treated and reference streams in Abram Creek. Lowercase letters show significant or non-significant differences between scores of treatment types 
Figure 12. Ecological Units (EU) in Abram Creek for diversity, brook trout, stocked trout, and overall fishery. This figure includes both 2013 and 2017 data. Diversity units in this figure represent macroinvertebrate diversity. Overall fishery units represent a combination of native brook trout and stocked trout.

Figure 13. Distribution of brook trout throughout the Abram Creek watershed. Symbols are site locations and sized based on the number of brook trout found at each site. Red dots indicate no brook trout were found at that sample location 


\section{Introduction}

The degradation of streams and rivers is widespread. According to the National Rivers and Streams Assessment, $46 \%$ of rivers and streams in the USA are in poor biological condition and only $28 \%$ in good condition (EPA 2016). Urbanization, agriculture, dams, and mining can all affect stream ecosystems by changing their hydrologic regimes and physicochemical conditions which can further influence the biological communities within them. Urbanization decreases infiltration and increases surface runoff (Dunne and Leopold 1978), which scours habitat and causes a shift toward more tolerant species (Walsh 2005). Agriculture increases the input of nutrients from fertilizers (Carpenter et al. 1998) and increases sediment transport without livestock exclusion (Line et al. 2000). Dams homogenize flows and alter water temperatures which can cause local aquatic and riparian communities to change and allow invasive species to thrive (Pusey et al. 1993, Poff \& Allen 1995, Bunn \& Arthington 2002). Mining operations can alter the chemistry of downstream waters and cause biotic communities to shift to more tolerant communities (Pond 2008). These decreases in ecosystem function and aquatic biodiversity have made river restoration a necessary component of natural resource management and has become an increasingly lucrative business in the past few decades (Bernhardt et al. 2005, Palmer et al. 2005, Lave et al. 2010).

While the need for restoration is increasingly understood, the best methods used for restoration projects are still under question. Hydromorphological restoration methods like Natural Channel Design (Rosgen 1998) are the most popular methods used by managers worldwide (Palmer et al. 2014). These methods use channel restructuring and bank armoring to increase habitat and decrease bank erosion during high flow events and are designed to regulate chemical and biological processes by constructing a stable and self-regulating channel without 
addressing any biotic or chemical processes (Rosgen 2011). However, in several instances, the re-grading of the stream bank reduced riparian vegetation and caused further erosion and incision (Violin et al 2011, Buchanan et al. 2012). Multiple studies have found that even when increased channel stability and habitat availability was achieved, biotic communities did not adequately respond to restoration efforts (see Palmer et al. 2014). This reflects the finding that while physical habitat may be ecologically important, it does not accurately measure ecological function (Doyle \& Shields 2012) nor does it always lead to biological restoration (Jahnig et al. 2010).

Additionally, in-stream restoration is commonly completed without first addressing outof-stream sources of degradation, which are likely the cause impairment in the first place. In many cases, passive measures such as repairing riparian zones or constructing wetlands can greatly improve stream conditions before any in-stream manipulations need to be applied (Kauffman et al. 1997). For example, the in-stream restoration of an urban watershed resulted in an increase in hyporheic exchange due to the increase in hydraulic conductivity by the addition of large cobbles and boulders into an urban streambed (Kasahara and Hill 2006). Later, however (2006), Kasahara and Hill found that while hyporheic exchange may initially increase, fine sediments common to urban and agricultural catchments coat the cobble and decrease hydraulic conductivity. They found anaerobic conditions in the hyporheic zone under these structures which suggested streambed clogging was occurring and oxygen and nutrient exchange were no longer improved (Kasahara and Hill 2006). Catchment level measures need to be taken to decrease sediment loads in order for in-stream structures to improve nutrient processing and habitat availability. 
Although site-specific restoration continues to fall short of management goals, studies using watershed-scale restoration are increasing but are still rare. In a meta-analysis of urban streams utilizing out-of-stream restoration approaches (stormwater ponds, created wetlands, restored riparian vegetation) with pre- and post-restoration data, investigators discovered significant improvements in measures of ecological attributes (136\%) and biodiversity (136\%) as compared to unrestored urban streams (Smucker \& Detenbeck 2014). Similar successes have occurred in agricultural regions where integrated catchment management has been applied. In New Zealand, the partial afforestation, livestock exclusion, and buffer planting of pasture lands at the catchment-level resulted in reductions in water temperature, runoff, and channel erosion, as well as improvements in summer baseflows, periphyton organic content, and macroinvertebrate indices that all showed a recovery trend towards reference forested stream conditions (Quinn et al. 2009). In a stream impacted by acid mine drainage (AMD), 3 years post watershed-scale remediation showed improvements in water quality which resulted in the reconnection of previously isolated stream networks as well as improvements in the biodiversity of fish and macroinvertebrate assemblages (Watson et al. 2017).

Many vital ecosystem processes occur over large spatial (i.e. watershed) scales and are important to consider in order to manage aquatic resources effectively. Multiple studies have characterized the important role the regional metacommunity plays in structuring local communities (Leibold et al. 2004) for both fish (Angermeier \& Winston 1998, Martin 2010, Stoll et al. 2014) and macroinvertebrates (Heino et al. 2003, Brown \& Swan 2010, Sundermann 2011, Merriam \& Petty 2016). It has been shown that biological communities of even pristine streams are affected by the proximity to nearby degraded streams or when they are isolated within a degraded watershed (Martin 2010, Merovich et al. 2013, Merriam \& Petty 2016). This follows 
the finding that in order for restored communities to receive new taxa there needs to be regional pools with seed populations within the dispersal limitations of the species (Heino et al. 2003, Parkyn \& Smith 2011, Sundermann 2011, Stoll et al. 2013). Additionally, because of the dendritic pattern of stream networks, dispersal usually involves greater distances than just overland distance between sites, which further constrains regional pool dispersal. This makes hydraulic connectivity a key component to successful stream restoration (Bernhardt \& Palmer 2011). Sundermann (2011) analyzed data from 24 river restoration projects and found improvements in benthic invertebrate communities where source populations of desired taxa were within $0-5 \mathrm{~km}$ of the restored site. Similarly, Lorenz and Feld (2013) found that the recolonization of stream organisms was achievable if good ecological conditions occurred within $5 \mathrm{~km}$ upstream of restoration sites for benthic invertebrates and macrophytes and within $10 \mathrm{~km}$ of restoration sites for fish. Therefore, an absence of connectivity to regional pool sources could be a large contributing factor for restorations which fail to meet managers' goals.

Local abiotic factors (e.g. pH, temperature, habitat) are important for community composition, but restoration projects that focus on this alone ignore important regional connectivity and dispersal effects and are likely to not meet restoration goals (Altermatt 2013, Stoll 2014). With these considerations in mind, strategic restoration plans which consider both local conditions and regional connectivity of watersheds or stream networks should be more successful for increasing biodiversity than just treating isolated reaches where dispersal and recolonization may be difficult (Bond \& Lake 2003, McClurg et al 2007, Louhi et al 2011, Sundermann et al. 2011, Stoll et al. 2013, Altermatt 2013). It is possible that through remediation efforts at this scale, the overall condition of the watershed could be improved. If so, it is expected 
that strategic watershed-scale remediation can provide benefits far beyond the sites which are actually restored.

The benefits of watershed-scale restoration are becoming more known as aquatic resource managers begin to switch their methods to this approach. Researchers utilize knowledge of hydrology, ecology, and geomorphology as well as social science in order to effectively restore streams across larger spatial scales by targeting problems at their source, sometimes beyond the channel, to maximize recovery. However, there are still unknowns which remain that are important to further develop watershed-scale management. First, long-term studies which assess the benefits of watershed-scale restoration are few (Palmer et al. 2014). Therefore, there are gaps in our long-term understanding of how biological communities respond to restoration efforts and the time-scales of when these responses occur. Additionally, there is a great need for studies that assess pre- and post-restoration monitoring data to better understand the mechanisms that affect restoration success or failure within this larger spatial-scale framework.

More particularly, long-term studies on the restoration successes/failures of acid mine drainage (AMD) are lacking, especially at the watershed scale. AMD is widespread in the midAtlantic region and is one of the most difficult environmental challenges facing managers in the area. When pyrite is exposed by mining operations, it is oxidized and sulfuric acid is released into the water system. This results in low $\mathrm{pH}$ levels, which allows toxic heavy metals to leach out and move through the water system (Hoffert 1947). In the mid-Atlantic region alone, it is estimated that $4,100 \mathrm{~km}$ of streams are acidic due to AMD and 17\% of the region's stream length is affected by some type of mine drainage, predominantly in the Appalachian ecoregions (Stoddard 2006). 
AMD is a legacy effect of mining, and the effects on aquatic environments are well known. $\mathrm{pH}$ can drop as low as 2.5 , iron that is initially dissolved within the water column can precipitate out to coat the stream bed, and other toxic metals (i.e. $\mathrm{Al}, \mathrm{Mn}$ ) are transported downstream and encrust habitats (DeNicola \& Stapleton 2002). This makes it difficult or impossible for macro-invertebrates and fish to survive and can change community compositions (Freund \& Petty 2007, Hogsden \& Harding 2012).

Treatments for AMD and acid precipitation utilize passive and/or active treatment systems. Passive treatment systems are low maintenance and use limestone and settling ponds to reduce acidity and dissolved metals. The most common passive method is the application of limestone sand directly into the stream or along the bank to where it slowly erodes into the stream. Limestone treatment has shown to be effective in improving $\mathrm{pH}$, water chemistry, and calcium concentrations in acid-impaired streams (McClurg 2007), but over time, high concentrations of aluminum and iron can form hydroxides that clog the limestone void space and reduce acid neutralization (Ziemkiewicz et al. 1997). In locations where passive systems are not effective enough, active treatment systems can be used to increase alkalinity. Active treatment systems intake water from the stream, treat it chemically to become alkaline, and then discharge the water back into the stream to reduce acidity of downstream waters.

While passive and active treatment methods have both been shown to improve water chemistry, ecological recovery does not always show improvement. Some studies have found that limestone treatment can increase macroinvertebrate and fish species richness (Weatherley et al. 1991, Downey et al. 1994, Menendez et al. 1996), while others have shown little to no recovery after treatment (Eggleton at al. 1996, Simmons and Doyle 1996, Bradley \& Ormerod 2002, LeFevre and Sharpe 2002). McClurg et al. (2007) sampled streams in West Virginia 
treated with limestone for acid precipitation and was unable to find any temporal trends in ecosystem recovery ranging from 2 to 20 years post-treatment. Although some water chemistry characteristics were fully recovered and native trout biomass was shown to increase, dissolved aluminum concentrations and macroinvertebrate and fish species richness were not recovered to reference conditions (McClurg et al. 2007). This suggests that even with targeted treatment of particularly bad reaches, regional condition of the stream networks surrounding these isolated reaches may inhibit restoration efforts. Expanding restoration to watershed-scale approaches could improve the success of these efforts (Watson et al. 2017). In 2010 and 2011, two such watershed-scale AMD remediation plans were implemented on Abram and Three Fork Creeks, West Virginia. Remediation plans involved a mixture of active and passive treatment systems, which were strategically placed to provide the most biologically beneficial and cost-effective plans for the watersheds (Petty et al. 2008, WVWRI 2007). However, the long-term ecological benefit of these restoration efforts remains unknown.

\section{Objectives}

The goal of my research is to provide information that can be used to improve stream and watershed restoration. To accomplish this, my overall objective is to assess the effectiveness of watershed scale restoration in two West Virginia watersheds that were severely impacted by acid mine drainage from legacy coal mining. It was previously stated that long-term assessments of stream restoration projects are needed to adequately inform and improve restoration science. This research provides the long-term requirement of an adaptive management framework where these results can improve these specific restoration projects as well as inform future projects with similar goals. Specifically, I aim to 1) quantify and compare benefits of watershed scale restoration to water quality and invertebrate and fish assemblages in Abram Creek (a cold-water 
ecosystem) and Three Forks Creek (a warm-water ecosystem) and 2) determine whether conditions in Abram Creek (a cold-water ecosystem) have improved, declined, or remained constant over an eight-year period of time. Abram Creek was sampled three times, providing an opportunity to assess any temporal changes in response to restoration. Three Forks was not included in objective 2 due to only having been sampled only twice.

\section{Methods}

Study Area- Three Forks Creek, a warm-water ecosystem, is a $262 \mathrm{~km}^{2}$ watershed within the Tygart Valley River and the greater Monongahela River basin (figure 1). The geology of the watershed is dominated by shale and sandstone formations. The dominant land cover and land use within the watershed are forested (78\%) and agricultural lands (12\%), respectively. Three Forks Creek flows from an elevation of 727 meters at the headwaters to 296 meters at the mouth. The largest tributaries of Three Fork Creek are Birds Creek, Fields Creek, Raccoon Creek, Squires Creek, and Laurel Run (figure 1). All major tributaries with the exception of Laurel Run have been severely degraded by AMD, with a total of $73 \mathrm{~km}$ of stream in the watershed listed as impaired (Pavlick et al. 2006). Approximately $37 \mathrm{~km}^{2}$ of untreated and discharging mine pools are found within the headwaters of the watershed, and Three Fork Creek is the second largest contributor of AMD in the Monongahela River basin (USACE 1997). The West Virginia Water Research Institute proposed a watershed restoration plan for Three Fork Creek in 2007 and the project was completed in 2011 by the WVDEP Office of Abandoned Mine Land and Reclamation. Four active treatment dosers were placed in the most impacted tributaries, Raccoon Creek, Birds Creek (2), and Squires Creek (figure 2). No passive treatment systems were used on Three Fork Creek. 
Abram Creek, a cold-water ecosystem, is a $115 \mathrm{~km}^{2}$ watershed within the North Branch Potomac River (NBPR) basin in the eastern panhandle of West Virginia (figure 2). Abram Creek flows north and falls from $1065 \mathrm{~m}$ elevation in the headwaters to $516 \mathrm{~m}$ elevation at its confluence with the NBPR. The dominant land use and land covers are forested lands (75\%) and agricultural lands (18\%), respectively. The West Virginia Department of Environmental Protection (WVDEP) identified 27 abandoned mine lands (AMLs) discharging into the Abram Creek watershed and identified this as the leading cause of impairment throughout the watershed (WVWRI 2007). Ten individual stream segments within the watershed were listed as impaired for biological and/or water quality impairment in 2004, failing to meet the stream's designated uses of recreation, public water supply, and aquatic life protection (WVWRI 2007). The main tributaries of Abram Creek are Emory Creek, Glade Run, Laurel Run, Little Creek, and Johnny Cake Run. All tributaries, with the exception of Johnny Cake Run, have been impacted by AMD. Johnny Cake Run was the only designated trout stream prior to AMD restoration. The West Virginia Water Research Institute proposed a watershed restoration plan for Abram Creek in 2007 and the project was completed in 2010 by the WVDEP Office of Abandoned Mine Land and Reclamation. Both active and passive restoration measures (i.e. alkaline dosers and limestone applications) have been strategically placed throughout the watershed to maximize restoration efforts (figure 2). A passive treatment system originally installed in Glade Run did not show desired effects after a couple years of treatment and was replaced by a limestone sand dumping site by WVDEP (J. Baczuk, personal communication, June 20, 2018).

Site Selection

This project followed a before-after-control-impact (BACI) sampling design. Sites were classified into 3 categories: untreated streams impaired by AMD (AMD sites), streams treated 
for AMD (treated sites), and unimpaired reference streams (reference sites). Targeted sites were strategically chosen based on treatment locations and stream confluences. Fourteen sites were sampled in Abram Creek in spring 2008 for water chemistry and macroinvertebrate sampling. An additional 3 un-impacted reference and 1 AMD site was added before fish sampling in the latesummer of 2008. The same sites, plus the additional 4 sites, were sampled again in 2013 postrestoration for all data collections. All 18 sites were sampled again in 2017 (table 1). In Three Forks Creek, 17 sites were sampled in 2008 prior to restoration. An additional 3 un-impacted reference sites were added before late-summer fish sampling in 2008. We sampled the same sites with the additional 3 un-impacted reference sites in 2017 for all data collections post-restoration (table 2).

\section{Data Collection}

Water quality was sampled during spring baseflows in 2008, 2013 (Abram Creek only), and 2017. Samples were collected between mid-May to mid-June each sampling year for both watersheds. All samples were collected using the same methods across both watersheds for each sampling year. We collected in-situ measurements of $\mathrm{pH}$, conductivity, temperature, and dissolved oxygen at each site using a YSI 600 XLM multiparameter probe at each sampling location. We collected grab samples at the same sample sites and stored them at $4^{\circ} \mathrm{C}$ until analysis is completed at the National Research Center for Coal and Energy at West Virginia University. The samples were analyzed for alkalinity/acidity, sulfate, and total dissolved aluminum, barium, copper, chloride ion, cobalt, chromium, cadmium, calcium, sodium, nickel, selenium, zinc, iron, magnesium, and manganese concentrations (mg/L).

We collected benthic macroinvertebrate samples immediately following water sample collection at each site in the late spring using WVDEP standard operating procedures (WVDEP 
2013). Kick samples were collected using a rectangular kick net (355 x 508 mm) with 500 um netting from 4 riffles and we combined them into a single sample for each site. We immediately preserved the organisms in $85 \%$ ethanol for identification in the lab. A 200 individual subsample was obtained and all organisms were identified to genus, if possible, using keys in Merritt and Cummins (2008).

Fish assemblages were sampled at each site following WVDEP standard protocol procedures during late summer baseflows (WVDEP 2013). Fish sampling was completed in both watersheds between mid-July and mid-September in 2008, 2013 (Abram Creek only), and 2017 using the same methods for both watersheds. We used one-pass backpack electrofishing techniques for all sites. One to three backpacks were used depending on stream size. Reach lengths were 40 times the mean stream width with a minimum of $150 \mathrm{~m}$ and a maximum of 300 m. All individuals were identified to species, measured, weighed, and released.

Statistical Analyses

Objective 1: Quantify and compare benefits of watershed scale restoration to water quality and invertebrate and fish assemblages in Abram Creek (a cold-water ecosystem) and Three Forks Creek (a warm-water ecosystem).

Water chemistry-We used multivariate tests and ordination procedures to characterize differences in chemical signatures of site types in 2017 in both creeks. Principal components analysis (PCA) was used to characterize the dominant patterns of variation within the water chemistry dataset. Prior to analysis, all chemicals except for $\mathrm{pH}$ and specific conductance were $\log +1$ transformed. Total acidity was removed from the analysis due to its correlation with other elements in the analysis (Merovich et al. 2007). Cadmium, chromium, and selenium were 
removed from the analysis due to all water samples being below the detection limit for these elements. Any concentrations below detection limit for other elements were assumed to have a concentration of zero for that element. Significant principal components were chosen using a broken stick analysis where principal components are retained when their corresponding eigenvalues are greater than their predicted broken stick values (Jackson 1993). Samples were grouped in ordination space by their stream type (reference, AMD, or treated). Non-metric analysis of variance using distance matrices (ADONIS) followed by pairwise permutation multivariate analysis of variance (MANOVA) was used to determine if PCA results differed between stream types. All PCA and ADONIS analyses were completed in the package vegan (Oksanen et al. 2013). AMD sites for Abram Creek were not included in pairwise comparisons due to only having one AMD site to include in analysis.

Aquatic assemblages-We calculated the Genus-Level Index of Most Probable Stream Status (GLIMPSS; Pond et al. 2013), which is a genus-level macroinvertebrate index of biotic made for the state of West Virginia. We used one-way analysis of variance (ANOVA) to test for significant increases in GLIMPSS scores of treated sites since restoration in Three Forks Creek followed by Tukey post-tests to compare index scores of treated and reference streams postrestoration. Due to Abram Creek having only one AMD and un-impacted reference site sampled in spring of 2008 for macroinvertebrates, we used one-way ANOVA to test increases in GLIMPSS scores within treated sites post-restoration followed by pairwise t-tests to compare treated and reference scores. We converted fish community data into measures of diversity using the Shannon Index for the 2008 and 2017 sampling years for both watersheds and then used repeated measures ANOVA and subsequent Tukey post-hoc tests to test for significant increases in restored sites after restoration. The additional un-impacted reference and AMD sites within 
both watersheds were added before fish sampling began which allowed us to use repeated measures ANOVA and Tukey tests for fish metrics in both watersheds. Our hypothesis was that we would see significant improvements in both metrics post-restoration.

It has been shown that species richness is strongly related to drainage area for fish in lotic systems. Because of this relationship, comparing species compositions between sites can be misleading due to the differences in drainage areas of reference sites and treated sites further downstream. To determine this relationship in Three Forks Creek and Abram Creek we made a linear model of drainage area, log transformed, for each of our sampling locations versus fish species richness for each creek. Previous research by our lab determined a relationship between fish species richness and drainage area at reference conditions for the region (i.e. no historical or current mining) (Martin 2010). We plotted this reference model as well as our linear models to determine how these restored creeks compare to regional reference conditions.

Ecological Units- During the planning phase of these restoration projects, methods which give the watershed an "ecological currency" were used to determine the best and most economical restoration project plan (Petty et al. 2008). This method uses a measurement tool called "EcoUnits" (EUs) as a way to quantify useable stream miles for specific functions (Petty and Thorne 2005, Merovich and Petty 2007, Petty et al. 2008, Poplar-Jeffers et al. 2009, Watson et al. 2017). Stream segment lengths are weighted by ecological function ranging from zero to one. A high quality stream segment with a weighting of one indicates it is reaching $100 \%$ of what is expected of high quality streams in the region. Stream segments with ratings of zero indicate the stream is highly impaired and not functioning ecologically. In Three Forks creek, we calculated four EUs: diversity EU, cold-water fishery EU, warm-water fishery EU, and overall fishery EU (Petty et al. 2008). In Abram Creek, EUs were calculated for macroinvertebrate 
diversity, brook trout fishery, stocked trout fishery, and overall fishery (Watson et al. 2017). West Virginia Stream Condition Index (WVSCI) scores were used to determine ecological conditions for each segment-level watershed for each measured function with condition weightings found in Petty 2007 (Three Forks Creek) and Watson 2017 (Abram Creek). EUs were calculated for each segment level watershed using these condition scores against their ecological potential for each segment. With this method, we obtained historical, predicted, pre-restoration, and current EUs for each segment which could be combined into cumulative EUs for each watershed. Kolmogorov-Smirnov (KS) tests were used to compare current EUs to predicted postrestoration EUs within each watershed.

Objective 2: Determine whether conditions in Abram Creek have improved, declined, or remained constant over an eight-year period of time (a cold-water ecosystem).

Water chemistry- Select water chemistry parameters were chosen to determine if water chemistry has changed temporally in treated locations since restoration. We selected alkalinity in equivalents of mg/L of $\mathrm{CaCO}_{3}$, aluminum, magnesium, and sulfate concentrations $(\mathrm{mg} / \mathrm{L})$ based on earlier research on an acid remediation project which identified these chemical parameters as important to study in acidic systems (McClurg et al. 2007). Concentrations of these parameters were compared by each sampling event (2008, 2013, and 2017) with one-way ANOVA and Tukey post-hoc tests to determine if continued increases are occurring post-restoration (i.e. 2013 to 2017$)$.

Aquatic Assemblages- For macroinvertebrates, we used one-way ANOVA and pairwise ttests to determine if GLIMPSS scores have increased within stream types with time since restoration followed by t-tests to compare indices scores between treated and reference streams. We converted fish community data into measures of diversity using the Shannon Index for the 
2008, 2013, and 2017 sampling years in Abram Creek. We then used repeated measures ANOVA and subsequent Tukey post-hoc tests to test for significant increases in restored sites over time. Previous research has shown significant improvements in fish and macroinvertebrate diversity 3-years post-restoration in Abram Creek (Watson 2017). Our hypothesis was that with continued long-term study, we would continue to see significant increases of macroinvertebrate and fish diversity temporally after 7-years post-restoration as this ecosystem continues to recover.

Eastern brook trout (Salvelinus fontinalis) are native to the Abram Creek watershed. The conservation of these fish are important to watershed managers and local communities alike. To visualize the possible expansion of the brook trout population post-restoration, ArcGIS was used to map site locations and symbol size indicates the number of individual brook trout found at each location during sampling. The natural breaks function was used to separate the symbol sizes into 5 classes $(0,1,2-14,15-33,>33)$ and the same symbol size classes were used for each year of sampling. No statistical analysis was done.

Ecological units- In Abram Creek, EUs were calculated for macroinvertebrate diversity, brook trout fishery, stocked trout fishery, and overall fishery. WVSCI scores were used to determine ecological conditions for each segment-level watershed for each measured function with condition weightings found in Watson 2017. EUs were calculated for each segment level watershed using these condition scores against their ecological potential for each segment. With this method, we obtained historical, predicted, pre-restoration, and current EUs for each segment which could be combined into cumulative EUs for the watershed. These scores were calculated post-restoration in 2013 (Watson 2017) and we calculated them again in 2017 to determine if 
EUs are changing temporally. KS tests were used to compare current EUs to predicted postrestoration EUs and EUs from 2013.

\section{Results}

Objective 1: Quantify and compare benefits of watershed scale restoration to water quality and invertebrate and fish assemblages in Abram Creek (a cold-water ecosystem) and Three Forks Creek (a warm-water ecosystem).

Water chemistry -PCA analysis for Three Forks Creek and Abram Creek were similar with well-defined water chemistry signatures for each site type. In Three Forks Creek, broken stick analysis resulted in two principal components (PCs) which together accounted for $73.1 \%$ of the variance in water chemistry. PC1 accounted for $48.7 \%$ of the variance and was strongly correlated with conductivity, sulfate, aluminum, cobalt, copper, iron, magnesium, manganese, nickel and zinc in the positive direction (figure 3, table 5). $\mathrm{pH}$ and alkalinity was strongly correlated with PC1 in the negative direction (figure 3, table 5). PC2 explained $24.4 \%$ of the variance of water chemistry and was strongly correlated with calcium, sodium, magnesium, and TSS in the positive direction and negatively correlated with aluminum (figure 3, table 5). ADONIS showed water chemistry differs by treatment type $(\mathrm{p}<.01)$ and pairwise permutation MANOVAs show that each stream type has a significantly different water signature from other stream types (all comparisons, $\mathrm{p}<.01$ ) (figure 3).

In Abram Creek, broken stick analysis resulted in three PCs which together accounted for $67.3 \%$ of the variance in water chemistry (table 6). Only PC1 and PC2 were included in the visual interpretation (figure 3). PC1 accounted for 34.6\% of the variance and was strongly correlated with conductivity, sulfate, calcium, cobalt, magnesium, manganese, nickel, and zinc in the positive direction and alkalinity and barium in the negative direction. PC2 accounted for $21.3 \%$ of variance and was strongly correlated with cobalt in the positive direction, and 
alkalinity, chlorine, barium, calcium, and sodium in the negative direction. Lastly, PC3 accounted for $11.4 \%$ of variation and was strongly correlated with chlorine and iron in the negative direction. Global ADONIS showed that water chemistry differs by stream type ( $\mathrm{F}=$ 6.91, $\mathrm{p}<.01)$ and pairwise permutation MANOVAs showed significant differences in water chemistry signatures between reference and treated sites $(\mathrm{p}<.01)$.

Aquatic assemblages- Macroinvertebrates in Three Forks and Abram Creek responded similarly to AMD remediation in each watershed. Comparisons of GLIMPSS scores show recovery toward reference conditions among treated sites (figure 4). One-way ANOVA indicated GLIMPSS scores differ by both year $(\mathrm{F}=28.54, \mathrm{p}<.01)$ and stream type $(\mathrm{F}=60.57, \mathrm{p}<.01)$ in Three Forks Creek. Tukey post-tests showed a significant increase in GLIMPSS in treated streams from pre- $(2008)$ to post-treatment $2017(\mathrm{t}=-6.16, \mathrm{df}=27, \mathrm{p}<.01)$ but did not reach reference conditions in $2017(\mathrm{t}=3.99, \mathrm{df}=27, \mathrm{p}<.01)$. However, 2017 treated sites were not significantly different from 2008 reference conditions $(t=2.72, d f=27, p=.06)$. Additionally, reference streams were not different from one another from 2008 to $2017(\mathrm{t}=-0.571, \mathrm{df}=27, \mathrm{p}=$ .94). Raw data for macroinvertebrates in Three Forks Creek are provided in appendices 6 and 7.

GLIMPSS scores in Abram Creek responded very similarly to Three Forks Creek (figure 4). One-way ANOVA within treated sites showed GLIMPSS scores differ by year ( $F=11.48, p<$ $.01)$ and stream type $(\mathrm{F}=29.81, \mathrm{p}<.01)$. Pairwise comparisons showed a significant increase in GLIMPSS scores in treated sites from pre- (2008) to post-restoration (2017) ( $\mathrm{t}=2.92, \mathrm{df}=30, \mathrm{p}<$ .01). Although scores in treated sites post-restoration did not reach reference conditions in 2017 $(\mathrm{t}=2.92, \mathrm{df}=30, \mathrm{p}=.03)$, post-restoration scores were not statistically different than reference conditions in 2008 (pre-restoration) $(\mathrm{t}=2.33, \mathrm{df}=30, \mathrm{p}=.11)$. GLIMPSS scores in reference sites 
were not different in 2008 and $2017(\mathrm{t}=-0.47, \mathrm{df}=30, \mathrm{p}=.97)$. Raw data for macroinvertebrates in Abram Creek are provided in appendices 3 and 5.

Fish communities responded differently to restoration than macroinvertebrates in both Three Forks and Abram Creeks. Appendices 1 and 2 provide raw fish data for Three Forks and Abram Creeks. In Three Forks Creek, fish diversity was variable among treated sites postrestoration (figure 5). One-way repeated measures ANOVA showed significant differences in diversity between years $(\mathrm{F}=9.66, \mathrm{p}<.01)$ and between types $(\mathrm{F}=25.29, \mathrm{p}<.01)$. Tukey post-hoc tests show a significant increase in diversity in treated streams from pre- (2008) to postrestoration (2017) $(\mathrm{t}=-3.683, \mathrm{df}=29, \mathrm{p}<.01)$. Tukey tests also showed no significant differences in diversity between reference streams pre- and post-restoration $(\mathrm{t}=-0.442, \mathrm{df}=29, \mathrm{p}=.97)$ as well as treated sites post-restoration and reference streams for $2008(t=1.917, d f=29, p=.24)$ and $2017(\mathrm{t}=2.37, \mathrm{df}=29, \mathrm{p}=.11)$.

Abram Creek showed a similar increase in fish diversity post-restoration (figure 5). In Abram Creek, one-way repeated measures ANOVA showed significant differences in fish diversity between years $(\mathrm{F}=9.16, \mathrm{p}<.01)$ and by stream type $(\mathrm{F}=11.88, \mathrm{p}<.01)$. Tukey post-hoc tests show significant increases in fish diversity post-restoration in treated sites compared to prerestoration $(\mathrm{t}=-3.474, \mathrm{df}=27, \mathrm{p}<.01)$. Additionally, fish diversity in treated sites post-restoration is not different than reference sites $(\mathrm{t}=1.406, \mathrm{df}=27, \mathrm{p}=.51)$. Reference sites did not show a change in diversity from pre- to post-restoration $(\mathrm{t}=-0.04, \mathrm{df}=27, \mathrm{p}=1.00)$.

Our linear models of drainage area to fish species richness show an interesting story (figure 6). When compared to regional intact fisheries, both Three Forks Creek and Abram Creek fail to reach expected drainage area to fish species richness relations post-restoration. On average, reference conditions of drainage area versus richness in the region shows an increase of 
3.2 species with every unit increase of drainage area and has a y-intercept of 0.6. Both watersheds have a lower slope than the regional curve for reference conditions. The linear model of drainage area versus species richness in Three Forks Creek showed a strong positive relationship $\left(\mathrm{R}^{2}=0.59, \mathrm{df}=18, \mathrm{p}<.01\right)$ (figure 6). On average, Three Forks Creek increases 2.5 species per unit increase in drainage area and has an intercept of -3.5. Abram Creek also showed a positive relationship between drainage area and species richness $\left(\mathrm{R}^{2}=0.31, \mathrm{df}=16, \mathrm{p}=.01\right)$ (figure 6). On average, species richness increases 0.85 with each unit increase in drainage area and has a y-intercept of 1.37 .

Ecological Units- EUs in Three Forks Creek reached predictions for macroinvertebrate diversity but was below predictions for all fishery EUs (figure 7). KS tests showed postrestoration diversity EUs did not accumulate at a different rate than predicted EUs for postrestoration $(D=0.08, p=.27)$ but also for pre-restoration EUs $(D=0.09, p=.17)$. Overall fishery EUs were much lower post-restoration than predicted but still accumulated more quickly than pre-restoration EUs $(D=0.56, \mathrm{p}<.01)$. Similarly, cold-water fishery EUs and warm-water fishery EUs were much lower than predicted post-restoration but accumulated more quickly than prerestoration EUs for cold-water $(D=0.60, p<.01)$ and warm-water fisheries $(D=0.58, p<.01)$. In total, $68 \%$ of historical diversity EUs and $19 \%$ of historical overall fishery EUs have been recovered. Overall fishery EUs were 84\% lower than predicted post-restoration.

Like other metrics, Abram Creek EUs are responding similarly to Three Forks Creek EUs (figure 8). Diversity EUs increased from 14.49 cumulative miles pre-restoration to 25.76 cumulative miles post-restoration. Historically Abram Creek had 34.66 functioning miles for macroinvertebrate diversity, so $74 \%$ of historic stream miles are now functional post-restoration as compared to $42 \%$ before the restoration project. KS tests show significant increases in the 
accumulation of diversity units from pre- and post-restoration $(D=0.42, p<.01)$. Additionally, post-restoration EUs in 2017 did not accumulate differently than what was predicted postrestoration $(\mathrm{D}=0.18, \mathrm{p}=.65)$. Like Three Forks Creek, Abram Creek fishery EUs did not recover to predicted EUs after restoration. Historically, it was expected that 34.66 cumulative miles of EUs existed in the watershed before any mining activity. It was degraded to 10.35 miles prerestoration and restored to only 14.97 miles in 2017. KS tests show that EUs did not accumulate at predicted rates post-restoration $(\mathrm{D}=0.36 \mathrm{p}=.03)$ nor were they different than pre-restoration $(\mathrm{D}=0.30, \mathrm{p}=.10)$. When split into stocked and brook trout EUs, stocked trout increased postrestoration $(\mathrm{D}=0.52, \mathrm{p}<.01)$ from pre-restoration EUs, but was much lower than predicted EUs $(\mathrm{D}=0.36, \mathrm{p}=.02)$. Stocked trout EUs increased by $33 \%$ post-restoration but only reached $47 \%$ of historical values. Brook trout EUs did not increase from pre-restoration EUs $(D=0.24, p=.29)$ so did not reach predicted EUs $(\mathrm{D}=0.52, \mathrm{p}<.01)$. Only 8.90 of historical 30.72 brook trout EUs were calculated to be functional post-restoration.

Objective 2: Determine whether conditions in Abram Creek have improved, declined, or remained constant over a nine-year period of time.

Water chemistry- Water quality parameters have not significantly changed since restoration was complete. One-way ANOVA followed by paired t-tests indicate the concentrations of alkalinity, aluminum, magnesium and sulfate have not significantly changed since restoration (i.e. 2013 to 2017) (figure 10). This tells us that any temporal ecological changes which occur are independent of changes in water chemistry post-restoration.

Aquatic assemblages- GLIMPSS scores follow similar patterns to water quality in treated sites (figure 11). One-way ANOVA within treated sites indicated that scores in treated streams differed by year $(\mathrm{p}<.01)$. Pairwise-tests show scores increased significantly in treated streams 
from 2008 to 2013 ( $\mathrm{p}=.04$ ), and is not statistically different from 2013 to 2017 ( $\mathrm{p}=.65$ ). Pairwise t-tests indicated GLIMPSS scores did not reach reference conditions in $2013(\mathrm{p}<.01)$ or 2017 $(\mathrm{p}=.01)$.

In contrast to macroinvertebrates, we are seeing a continued increase in fish diversity temporally (figure 13). Diversity increased significantly $(\mathrm{p}=.03)$ from pre-treatment (2008) to 3years post treatment (2013) and again from 3- to 7-years (2017) post treatment within and downstream of treated segments $(\mathrm{p}=.04)$. We found no significant difference in fish diversity between reference and treated streams in either 2013 or 2017.

Brook trout populations were also found to increase and spread throughout the watershed (figure 13). A total of 88 brook trout were found in 5 sample locations prior to restoration (i.e. 2008). The number of sites occupied by brook trout increased to 6 in 2013 and 11 in 2017, with 131 individuals being captured in 2017. 23 brook trout were found in the two most southern headwater sites in 2017 where previous years found none. Four of the 11 sites found to occupy brook trout in 2017 had only one brook trout in the sample. The majority of brook trout were found in the headwaters and tributaries rather than the main stem of Abram Creek.

Ecological Units- Ecological units are not showing any temporal changes post-restoration (figure 12). Historically, 34.66 cumulative stream miles of macroinvertebrate diversity EUs were predicted to have existed in Abram Creek before mining. Before restoration, only $41 \%$ of possible EU's remained. In 2013, diversity EU's increased to 25.54 cumulative miles or $74 \%$ of historical EUs which surpassed the predicted EUs of 67\% of historical EUs. In 2017, little changed and $74 \%$ of historic diversity EUs have been recovered. KS tests did not show any changes in EU accumulation between 2013 and $2017(\mathrm{D}=0.09, \mathrm{p}=.99)$. Brook trout EUs did not show any further recovery to predicted conditions in 2017 and was actually lower than 2013. In 
$2013,33 \%$ of historic brook trout EUs were recovered but was only $54 \%$ of what was predicted post-restoration. Similarly in 2017 , only $47 \%$ of predicted EUs were recovered for brook trout. Kolmogorov-Smirnov tests show that brook trout EUs are not accumulating at a different rate than pre-restoration EUs for either year (2013: $D=0.24, p=.29 ; 2017: D=0.24, p=.29)$. Stocked trout and overall fishery show similar results. Stocked trout EUs only achieved $78 \%$ of predicted EUs in 2013 and decreased to 51\% in 2017. KS tests show that although stocked trout EUs accumulated similarly to predicted in $2013(\mathrm{D}=0.27, \mathrm{p}=.17)$, EUs accumulated at a lower rate than predicted in 2017 ( $D=36, p=.03$ ), but 2013 and 2017 EUs accumulated similarly ( $D=0.30$, $\mathrm{p}=.10$ ). Overall fishery EUs achieved 85\% of predicted EUs in 2013 but only 66\% in 2017. Similar to the stocked trout fishery, overall fishery EUs did not accumulate differently from predicted in $2013(\mathrm{D}=0.27, \mathrm{p}=.17)$ but accumulated differently in $2017(\mathrm{D}=0.36, \mathrm{p}=.03)$. Additionally, overall fishery EUs did not accumulate differently in 2017 than pre-restoration $(D=$ $0.30, \mathrm{p}=.10)$.

\section{Discussion}

The number of stream restoration plans which properly identify goals, have pre- and postrestoration monitoring, and are planned to the appropriate scale (i.e. watershed-scale) are few. While there has been a recent increase in projects with pre- and post-restoration monitoring, few projects have used watershed scale approaches or appropriate timescales to achieve restoration goals (Hilderbrand et al. 2005, Palmer et al. 2014). The overall objective of our study was to determine the effectiveness of two stream restoration projects in West Virginia which were completed at the watershed scale, have pre- and post-monitoring ecological data, and had predetermined goals for stream chemistry and associated ecological functions. 
Objective 1: Quantify and compare benefits of watershed scale restoration to water quality and invertebrate and fish assemblages in Abram Creek (a cold-water ecosystem) and Three Forks Creek (a warm-water ecosystem).

Three Forks and Abram Creeks were severely degraded pre-restoration. It was estimated that while historically there were approximately $40 \mathrm{~km}$ of fishable water, only $5 \mathrm{~km}$ remained due to extensive pre-law mining within the Three Forks Creek watershed (Petty et al. 2008) and a total of $73 \mathrm{~km}$ of streams within the watershed were considered impaired pre-restoration (Pavlick et al. 2006). The goals of this stream restoration project set by the WVDEP were to improve water chemistry and aesthetics in order to increase recreational use while also restoring macroinvertebrate and fish communities (WVDEP 2013).

Water chemistry results indicate significant improvements post-restoration in treated sites within the watersheds. Although still intermediary between AMD impaired and reference conditions alkalinity and $\mathrm{pH}$ increases with consequent decreases in heavy metals have pushed chemical conditions toward reference conditions. Some chemicals, like sulfate and magnesium, are extremely difficult to reduce with this type of AMD remediation (i.e. in-stream treatment) and are still elevated post-treatment in Three Forks Creek (table 3) and Abram Creek (table 4) (Freund \& Petty 2007). This combined with increased levels of TSS and Na, highly correlated with PC2 (figure 3), are the likely reasons for separation of chemical signatures between reference and treated sites. Due the extent of impairment, our results show it is unlikely that water chemistry will ever fully reflect unimpaired reference conditions with this type of instream treatment. Even so, it should be noted that the water quality improvements throughout the watersheds are extensive and have not only improved conditions within the creeks themselves, but likely the rivers to which they drain. 
Macroinvertebrate communities are showing large improvements post-restoration in both watersheds and their responses are very similar. Both watersheds are showing a significant increase of GLIMPSS in treated sites post-restoration which are approaching reference conditions. This is reflected in how both watersheds show that while treated sites were significantly different than reference sites in 2017 , they were not different than reference sites from 2008. This suggests the improvement of the macroinvertebrate communities in the treated sites could be inflating the communities at the watershed scale even though reference scores were not statistically different from pre- to post-restoration. Additionally, GLIMPSS scores in both watersheds show that reference and treated sites have significantly different scores in 2017. This difference in the genus level measure suggests that although improvements are being made functionally and we are seeing increases in EPT values, certain taxa may not be returning to these sites. McClurg et al. (2007) found that in treated acidic streams, there was considerable variation in benthic macroinvertebrate communities based on the distance to treatment. Mixing zones which were less than $2 \mathrm{~km}$ downstream of treatment caused highly variable water quality and benthic macroinvertebrate communities which more closely resembled untreated acidic sites rather than unimpacted reference sites and treated sites further downstream from treatment. Site locations within Three Forks Creek and Abram Creek vary throughout the watersheds in proximity to treatment and the variability in community structures may be reflected in this relationship. Additionally, if treated and reference streams are isolated within the watershed, it is possible that a surrounding metacommunity with a deflated species pool could be affecting the ability of certain taxa to reach these streams (Merriam \& Petty 2016).

Fish diversity is greatly improving throughout the Three Forks Creek watershed. Prior to restoration, fish were only found in reference sites not impacted by acid mine drainage and many 
considered the main stem of Three Forks Creek to be "dead". Now we are seeing fish diversity improve in treated sites as reference sites are now connected to more of the watershed and as water quality allows fish movement in and out of the watershed. However, within treated sites there is high variability in diversity. Many impacted tributaries and upstream main stem sites have no fish or are dominated by one or two tolerant species (e.g. creek chub, Semotolis atromaculatus, and blacknose dace, Rhinichthys atratulus). As water quality improves downstream, more species were found within our sites (appendix 1). Like Three Forks Creek, Abram Creek is also showing great improvements in fish diversity across treated sites and were not different from reference diversity scores. Variability, however, is less in Abram Creek. Only one site in Abram Creek has a diversity score of zero compared to multiple sites in Three Forks Creek. A few explanations of this discrepancy could be 1) Abram Creek is less than half the size of Three Forks Creek so distance for source populations to travel to occupy treated sites may be less (Lorenz \& Feld 2013), 2) the state of the regional species pool could be different between the two watersheds depending on the regional condition surrounding the watersheds (Martin 2010, Merriam \& Petty 2016) or 3) the volume of AMD in some locations just may be so extensive that in-stream treatment is not effective enough to restore a functioning fishery (Freund $\&$ Petty 2007). The effect of regional species pools on the ability of restored streams to be repopulated has become more explored recently (Martin 2010, Merriam \& Petty 2016) and may be an interesting factor to further explore. Additionally, it is important to note improvements of diversity do not indicate species' abundances which is likely the discrepancy in our results between the apparent diversity improvements and the failure to recover functional fisheries with EUs and our linear models. 
The possible effect of the regional species pool on species composition in these restored sites is possibly seen in figure 8, the linear models of drainage area to fish species richness. Fish communities show a strong relationship with drainage area in stream networks (Allan 2004, Guégan et al. 1998, Martin 2010, Matthews \& Robinson 1998, Palmer \& White 1994). Species richness typically increases with drainage area and Three Forks and Abram Creek is no exception. Although this relationship is well documented, the comparison between our two watersheds and regional reference conditions are showing discrepancies. While Abram Creek has a similar y-intercept to reference conditions, the reduced y-intercept for Three Forks Creek indicates a delay in species richness in smaller drainages amongst treated and untreated AMD sites. As discussed earlier, many treated sites of small drainages and close to treatment had either no fish or only one species when sampled and all untreated AMD sites had no fish. We do know the proximity to treatment creates variable water chemistry and it is well known that most fish species cannot tolerate even low levels of dissolved metals (Pinder \& Morgan 1995, Welsh \& Perry 1997, Maret \& MacCoy 2002). While this could indicate a delayed response in fish richness as water quality improves downstream, we do not see the same response in Abram Creek.

We are also seeing a reduced slope in the relationship between richness and drainage area for both watersheds. Continued elevated levels of sulfates and specific conductivity in treated sites are likely affecting the ability of fish to repopulate the watershed. Freund and Petty (2007) found both sulfate concentrations and specific conductance to be strong predictors of fish presence in the mining area of Appalachia. The continued elevation of these chemical parameters, even in treated sites, is likely reducing the effect of drainage area to richness in both watersheds. These results follow earlier studies which have found that while there is a decrease 
in heavy metals and increase in alkalinity, even low levels of these chemicals can combine to cause biological impairment even if none of the individual concentrations exceed water quality criteria (Freund \& Petty 2007).

It is possible the differences seen are because we are comparing a cold-water system (Abram Creek) to a warm-water system (Three Forks Creek). The only reference streams within both watersheds are small tributaries which provide the core populations which sustain coldwater fisheries (Hense 2007, Huntsman \& Petty 2014). Abram Creek has an intact, functional headwater tributary in which to sustain core populations of cold-water fish. Warm-water fisheries tend to develop further downstream with larger drainages and higher temperatures but sites with these characteristics in Three Forks Creek are all downstream of AMD and treatment. Healthy tributaries in Abram Creek may be keeping the cold-water fishery intact by being the source for treated locations in the watersheds (i.e. sinks) while warm-water fisheries in Three Forks struggle to gain a foothold due to no known intact warm-water fisheries within the Three Fork Creek regional species pool. Our results indicate that cold-water fisheries may be easier to restore than warm-water fisheries if core habitat remains intact in some of the headwaters.

Regional condition of the Three Forks watershed is likely hindering the ability of full recovery of fish species within the watershed. When looking at the linear relationship between species richness and drainage area, you can see that unlike Abram Creek, reference sites not impacted by AMD within the Three Forks watershed are not reaching the expected reference condition. This discrepancy not only suggests watershed-level impairment, but also that the regional conditions which surround the Three Forks Creek watershed may be affecting the ability of the fish community to recover. Merovich et al. (2013) shows the impact of mining on ecological integrity in the Tygart and Cheat watersheds which both drain north into the 
Monongahela River. The Tygart watershed has good water quality and ecological integrity in the upstream sections but poor conditions in the lower sections of the watershed due to extensive pre-law mining. Three Forks Creek is located in the lower (i.e. northern) section of the Tygart Valley watershed and is surrounded by other HUC-10 watersheds which show poor conditions. Due to the extensive mining and reduced conditions of the Three Forks watershed and beyond, regional conditions may restrict the ability of Three Forks Creek to recover. Additionally, Three Forks Creek flows into the Tygart River below the dam which creates Tygart Lake. This blockage to fish movement may be further hindering the ability of fish to move into Three Forks Creek from the upper parts of the watershed where conditions are better into the lower part of the watershed which is more impacted by mining. This is not seen in the reference sites of Abram Creek. Abram Creek connects to the North Branch of the Potomac River. Although the North Branch also has its history with AMD and is also dammed, it still has intact fisheries in its tributaries (Savage River, for example) to supply a regional species pool to help populate both Abram Creek's reference and sink habitats. Future restoration projects may need to consider the condition of regional species pools to determine if the ecological restoration of fish is a plausible goal.

From a different perspective, fishery related EUs for Three Fork Creek and Abram Creek came up short of predictions for the restoration projects. Our fish diversity results show diversity scores significantly improving and reaching our reference conditions in both watersheds but EUs and our linear models indicate we are not achieving a functioning fishery. This indicates that although diversity is improving, fisheries are not developing which could indicate a density issue. It was predicted that the majority of the historic warm-water fishery would be recovered in Three Fork Creek post-restoration, and the warm-water fishery was predicted to have a better 
recovery than the cold-water fishery due to warm-water habitats being far enough downstream of treatment to have stable conditions for fish. Our findings show that the fishery has not had much of a recovery when compared to pre-restoration with warm-water EUs only accumulating 1.3 additional functioning stream miles post-restoration. Similarly, Abram Creek only recovered 0.3 miles of brook trout EUs and 4.2 miles of stocked trout EUs. These findings along with our linear models showing a depressed fishery tell us that although these restoration projects successfully recovered macroinvertebrate (i.e. WVSCI) EUs and fish diversity has increased, it was not able to recover a functional fishery within the watershed. It will likely require out of stream (i.e. at source) treatment to recover functioning fisheries in watersheds with this extensive of impairment.

Objective 2: Determine whether conditions in Abram Creek have improved, declined, or remained constant over an eight year period of time.

We are not seeing any temporal changes in Abram Creek for water quality since sampling in 2013. Although liming dosers are adjusted as needed to meet water quality goals, treatment has not significantly changed since restoration began in 2011. Even with increases in alkalinity throughout treated sites, some difficult to treat compounds, like aluminum, magnesium, and sulfate, have not decreased in concentration post-restoration. The continued presence of these chemicals are likely the reason for benthic macroinvertebrates to have continued GLIMPSS scores which are lower than reference sites within the watershed. Freund and Petty (2007) found benthic macroinvertebrate communities were highly correlated with water quality parameters which are common in mined watersheds. Their relationship to water quality, even with the reconnection of reference streams to the rest of the watershed, will likely continue to suppress macroinvertebrate taxa with low tolerance to water chemistry changes. 
Fish, however, are continuing to change post-restoration within the Abram Creek watershed. Diversity increased and communities improved two years post-restoration and we are still seeing improvement six years post-restoration. It is also interesting that in addition to the increase in fish diversity from 2013 to 2017 the variability within treated sites is decreasing temporally as more taxa are occupying more treated sites and being less dominated by one or two taxa through time.

This temporal spread of fish throughout the watershed is well represented in figure 13 which shows how brook trout populations have expanded to use more of the watershed through time. Before restoration, brook trout could only occupy two reference tributaries which were not affected by AMD. Additionally, these tributaries were isolated from each other due to acidic conditions throughout the main stem of Abram Creek which caused a block to movement. When fish were sampled post-restoration in 2013, there was little change in brook trout populations but by 2017, brook trout were not only moving throughout the watershed, but also occupying many more locations throughout the watershed. Surprisingly, brook trout are being found in the headwater tributaries of Abram Creek which have large inputs of AMD (figure 13) as well as being close to the liming dosers which can cause highly variable water quality for up to $2 \mathrm{~km}$ downstream (McClurg 2007).

This continued movement of fish through time from our reference (source) populations to our treated sites (sinks) is suggesting inflation of the fish community at the watershed scale. McClurg (2007) showed that the limestone treatment of streams at the reach scale resulted in no temporal improvements of ecological functions due to treating localized areas which still drain highly acidic watersheds. Our study shows that through the reconnection of healthy tributaries to the rest of the watershed, fish communities can live in locations which are still suffering from 
water quality parameters which are usually not ideal. These source-sink dynamics between reference streams and treated streams are likely the reason we are seeing continued improvements in the Abram Creek watershed (Pullium 1988). Because reference streams where brook trout and other sensitive fish are able to reproduce are still present within the watershed, populations can be sustained outside of these reference conditions due to mass effects.

It could also be argued that this restoration could be forming ecological traps. Ecological traps are newer idea to ecology, and even less studied in stream restoration. Ecological traps are a result of environmental change and occur when low quality habitats become as attractive as or more attractive than higher quality habitats to organisms. Robertson and Hutto (2006) state three scenarios with which an area has to fulfill at least one of to be considered an ecological trap. Stream restoration projects fit well into the scenario where a settlement cue is changed so that an organism may see it as an attractive habitat but the suitability of the habitat for that settlement purpose has not changed (Robertson and Hutto 2006). Whereas source-sink dynamics is population based, the idea of ecological traps is based on a behavioral modification where environmental ques are changed which attract species to populate an area that is still unsuitable for other reasons (Robertson and Hutto 2006). In the treated tributaries within our watersheds, $\mathrm{pH}$ and alkalinity have increased but metals and conductivity remain elevated. In Abram Creek particularly, where we are seeing the expansion of brook trout, alkalinity is high enough for brook trout to live (i.e. above $7 \mathrm{mg} \mathrm{CaCO}_{3} / \mathrm{L}$ (Petty et al. 2005)) and move into the small tributaries for spawning, but continued elevated conductivity and metal concentrations are likely hindering recruitment. Therefore we are "attracting" brook trout to repopulate some tributaries which are not fully functional which may hinder the local population due to low recruitment success. While this may be a negative result of restoration, we are hopeful that restoring at the 
watershed scale has improved the linkage of high quality source habitats which can support the local populations even with the existence of traps.

Our results indicate that with the treatment of acidic watersheds at the watershed scale, fish communities can improve dramatically but, because of the apparent delay in fish response to restoration, it takes long-term monitoring in order to see these improvements. Many restoration projects monitor biological changes only a few years post-restoration. Our results from 2013 show improvements in fish populations post-restoration but populations did not reach reference conditions with only a few years to recover and repopulate the watershed. It took monitoring six years post-restoration to detect these changes and it is likely that changes will continue into the future.

A study by Watson (2017) measured restoration "success" using a method which turns ecological attributes into "ecological currency" (Petty et al. 2008). Watson (2017) found that although predicted goals for macroinvertebrate diversity were met by this restoration project, the other EUs, stocked trout, brook trout, and overall fishery, did not meet predicted goals. We continued this study using 2017 data to determine if any temporal trends were present in recovering predicted EUs for this restoration project. Our results show that there were no significant changes between 2013 and 2017 and the same predicted EUs were not met. This makes sense by the previous results in our study. Macroinvertebrates were not shown to significantly change from 2013 to 2017 and the calculation of EUs for all categories is based on WVSCI scores from macroinvertebrates. Our results show that even though macroinvertebrates are not changing, fish are continuing to change. Brook trout populations expanded throughout the watershed in 2017 even though the brook trout EUs are showing lower cumulative brook trout fishery units in 2017 than 2013. Because EUs for brook trout are predicted by the WVSCI 
scores of high quality streams they usually occupy, it may not be adequately predicting that brook trout can still be found in sink habitats where water quality is not as high. It is possible that through the remediation of acidic streams at the watershed scale, brook trout and other sensitive populations can not only be reconnected to each other within reference streams, but also expand into streams which we may not usually predict their presence.

\section{Management Implications}

Future research on these watersheds should focus on the discrepancy between increased fish diversity to reference conditions and the continued lack of functional fisheries. Density metrics which explore species abundances as well as documenting the presence/absence of certain species or functional groups of fish may help explain why fisheries in both watersheds are not fully recovering. This data will be needed if managers plan to improve the fisheries of Abram and Three Forks Creek. Additionally, further macroinvertebrate analysis can give valuable insight into what taxa are not returning to our treated locations and whether or not functional diversity in our treated locations is comparable to our reference sites. This information could help managers predict the ability of AMD restoration to repopulate sensitive taxa.

Historically, stream restoration projects have focused at the reach-scale without concern of watershed or regional-scale processes which surround them. Multiple studies have found these site-specific, reach scale approaches are not seeing the biological uplift expected due to the strict focus of habitat improvement rather than the reconnection of isolated populations or not fully addressing the sources of impairment at the watershed-scale (McClurg 2007, Palmer et al. 2014). In a study of fish populations in the central Appalachians, Martin (2010) found that local biological conditions were independent of local conditions for stream fishes. This finding supports that site-specific restorations are not going to find the biological improvements only by 
improving habitat or water quality at the local scale. Further, with macroinvertebrates, although they are usually a good indicator of local water quality (Freund and Petty 2007), regional processes (i.e. dispersal) dictate the communities that will reside there (Merriam \& Petty 2016).

Our results clearly show the benefits of focusing restorations at the watershed-scale. Some biological and chemical attributes are still not fully recovered in either watershed, but that is expected due to the severity of impairment which AMD causes and the infeasibility of complete restoration in these systems. Still, macroinvertebrate indices and fish diversity were greatly improved in both Abram Creek and Three Fork Creek due to the improved water chemistry and reconnection of isolated tributaries which serve as sources to repopulate the watersheds. Our results indicate that restoration projects which focus at the watershed scale to improve connections to good conditions both locally and regionally are expected to be more successful than improving local conditions alone. Our results, especially at Abram Creek, also show that it may take long time frames to see the full benefits of restoration and for biological communities to fully recover.

Regional impairment beyond the watershed may also affect the ability of a stream to recover. Three Forks Creek is showing great improvements for macroinvertebrates throughout our restored reaches, but fish are still struggling to repopulate the watershed due to high regional impairment and a blockage to fish movement (i.e. Tygart Lake dam). Although this restoration project was largely focused on improving water quality before reaching the Tygart River, future restoration projects may need to focus regionally to reconnect healthy watersheds to restored areas. Additionally, the differences in recovery between macroinvertebrates and fish in our watersheds suggest that monitoring both fish and macroinvertebrates should be a part of ecological monitoring programs. Macroinvertebrates can give managers a good idea of local 
conditions but fish may be able to tell a larger story of regional condition both within the watershed and beyond.

Our results can help watershed managers by showing that long-term monitoring and regional-scale thinking can help to improve restoration projects. With the completed cycle of our adaptive management framework, our results can be used to address successes, shortcomings, and where changes can be made to continue to improve the ecological condition of these watersheds. Our results also show that even with huge improvements, full recovery of macroinvertebrate and fisheries to reference conditions of systems highly degraded by AMD may not be possible without at-source treatment. Even so, our results show that watershed-scale restoration leads to many ecological improvements and regional-scale processes play a large role in ecosystem recovery. 


\section{Literature Cited}

Allan, J. D. (2004). Landscapes and riverscapes: the influence of land use on stream ecosystems. Annu. Rev. Ecol. Evol. Syst., 35, 257-284.

Altermatt, F., Seymour, M., \& Martinez, N. (2013). River network properties shape $\alpha$-diversity and community similarity patterns of aquatic insect communities across major drainage basins. Journal of Biogeography, 40(12), 2249-2260.

Angermeier, P. L., \& Winston, M. R. (1998). Local vs. regional influences on local diversity in stream fish communities of Virginia. Ecology, 79(3), 911-927.

Barbour, M. T., Gerritsen, J., Synder, B. D., \& Stribling, J. B. (1999). Rapid bioassessment protocols for use in wadeable streams and rivers: periphyton, benthic macroinvertebrates, and fish. United States. Environmental Protection Agency, Office of Water.

Bernhardt, E. S., Palmer, M. A., Allan, J. D., Alexander, G., Barnas, K., Brooks, S., ... Sudduth, E. (2005). Synthesizing U.S. River Restoration Efforts. Science, 308(5722), 636-637.

Bernhardt, E. S., \& Palmer, M. A. (2011). River restoration: the fuzzy logic of repairing reaches to reverse catchment scale degradation. Ecological applications, 21(6), 1926-1931.

Bond, N. R., \& Lake, P. S. (2003). Local habitat restoration in streams: constraints on the effectiveness of restoration for stream biota. Ecological Management \& Restoration, 4(3), 193-198.

Bradley, D. C., \& Ormerod, S. J. (2002). Long-term effects of catchment liming on invertebrates in upland streams. Freshwater Biology, 47(1), 161-171.

Brown, B. L., \& Swan, C. M. (2010). Dendritic network structure constrains metacommunity 
properties in riverine ecosystems. Journal of Animal Ecology, 79(3), 571-580.

Buchanan, B. P., Walter, M. T., Nagle, G. N., \& Schneider, R. L. (2012). Monitoring and assessment of a river restoration project in central New York. River Research and Applications, 28(2), 216-233.

Bunn, S. E., \& Arthington, A. H. (2002). Basic Principles and Ecological Consequences of Altered Flow Regimes for Aquatic Biodiversity. Environmental Management, 30(4), $492-507$.

Carpenter, S. R., Caraco, N. F., Correll, D. L., Howarth, R. W., Sharpley, A. N., \& Smith, V. H. (1998). NONPOINT POLLUTION OF SURFACE WATERS WITH PHOSPHORUS AND NITROGEN. Ecological Applications, 8(3), 559-568.

DeNicola, D. M., \& Stapleton, M. G. (2002). Impact of acid mine drainage on benthic communities in streams: the relative roles of substratum vs. aqueous effects. Environmental Pollution, 119(3), 303-315.

Downey, D. M., French, C. R., \& Odom, M. (1994). Low cost limestone treatment of acid sensitive trout streams in the Appalachian mountains of Virginia. Water, Air, and Soil Pollution, 77(1-2), 49-77.

Doyle, M. W., \& Douglas Shields, F. (2012). Compensatory Mitigation for Streams Under the Clean Water Act: Reassessing Science and Redirecting Policy1. JAWRA Journal of the American Water Resources Association, 48(3), 494-509.

Dunne, T., \& Leopold, L. B. (1978). Water in environmental planning. Macmillan.

Eggleton, M. A., Morgan, E. L., \& Pennington, W. L. (1996). Effects of Liming on an Acid- 
Sensitive Southern Appalachian Stream. Restoration Ecology, 4(3), 247-263.

Freund, J.G., Petty, J.T. (2007) Response of fish and macroinvertebrate bioassessment indices to water chemistry in a mined Appalachian watershed. Environmental Management, 39(5), 707-720.

Gerritsen, J., Burton, J., \& Barbour, M. T. (2000). A stream condition index for West Virginia wadeable streams. Tetra Tech, Inc., Owings Mills, Maryland, USA.

Guégan, J. F., Lek, S., \& Oberdorff, T. (1998). Energy availability and habitat heterogeneity predict global riverine fish diversity. Nature, 391(6665), 382.

Heino, J., Muotka, T., \& Paavola, R. (2003). Determinants of macroinvertebrate diversity in headwater streams: regional and local influences. Journal of Animal Ecology, 72(3), 425434.

Hense, Zina. "Stream Fish Populations in a Watershed Scale Context for Fish Community Dynamics in Central Appalachian Watersheds." Order No. 1451711 West Virginia University, 2007. Ann Arbor: ProQuest. Web. 20 Apr. 2019.

Hilderbrand, R. H., Watts, A. C., \& Randle, A. M. (2005). The myths of restoration ecology. Ecology and society, 10(1).

Hoffert, J. R. (1947). Acid Mine Drainage. Industrial \& Engineering Chemistry, 39(5), 642-646.

Hogsden, K. L., \& Harding, J. S. (2012). Anthropogenic and natural sources of acidity and metals and their influence on the structure of stream food webs. Environmental pollution, 162, 466-474.

Huntsman, B. M., \& Petty, J. T. (2014). Density-dependent regulation of brook trout population 
dynamics along a core-periphery distribution gradient in a central Appalachian watershed. PloS one, 9(3), e91673.

Jackson, D. A. (1993). Stopping rules in principal components analysis: a comparison of heuristical and statistical approaches. Ecology, 74(8), 2204-2214.

Jähnig, S. C., Brabec, K., Buffagni, A., Erba, S., Lorenz, A. W., Ofenböck, T., ... \& Hering, D. (2010). A comparative analysis of restoration measures and their effects on hydromorphology and benthic invertebrates in 26 central and southern European rivers. Journal of Applied Ecology, 47(3), 671-680.

Kasahara, T., \& Hill, A. R. (2006). Hyporheic exchange flows induced by constructed riffles and steps in lowland streams in southern Ontario, Canada. Hydrological Processes, 20(20), $4287-4305$.

Kasahara, T., \& Hill, A. R. (2006). Effects of riffle step restoration on hyporheic zone chemistry in N-rich lowland streams. Canadian Journal of Fisheries and Aquatic Sciences, 63(1), 120-133.

Kauffman, J. B., Beschta, R. L., Otting, N., \& Lytjen, D. (1997). An ecological perspective of riparian and stream restoration in the western United States. Fisheries, 22(5), 12-24.

Lave, R., Doyle, M., \& Robertson, M. (2010). Privatizing stream restoration in the US. Social Studies of Social Science, 40(5), 677-703.

LeFevre, S. R., \& Sharpe, W. E. (2002). Acid stream water remediation using limestone sand on Bear Run in Southwestern Pennsylvania. Restoration Ecology, 10(2), 223-236.

Leibold, M. A., Holyoak, M., Mouquet, N., Amarasekare, P., Chase, J. M., Hoopes, M. F., ... 
Gonzalez, A. (2004). The metacommunity concept: a framework for multi-scale community ecology. Ecology Letters, 7(7), 601-613.

Line, D. E., Harman, W. A., Jennings, G. D., Thompson, E. J., \& Osmond, D. L. (2000). Nonpoint-source pollutant load reductions associated with livestock exclusion. Journal of Environmental Quality, 29(6), 1882-1890.

Lorenz, A. W., \& Feld, C. K. (2013). Upstream river morphology and riparian land use overrule local restoration effects on ecological status assessment. Hydrobiologia, 704(1), 489-501.

Louhi, P., Mykrä, H., Paavola, R., Huusko, A., Vehanen, T., Mäki-Petäys, A., \& Muotka, T. (2011). Twenty years of stream restoration in Finland: little response by benthic macroinvertebrate communities. Ecological Applications, 21(6), 1950-1961.

Maret, T. R., \& MacCoy, D. E. (2002). Fish assemblages and environmental variables associated with hard-rock mining in the Coeur d'Alene River basin, Idaho. Transactions of the American Fisheries Society, 131(5), 865-884.

Martin, R. W. (2010). Stream fish metacommunity and metapopulation ecology in a mined Appalachian watershed. West Virginia University.

Matthews, W. J., \& Robison, H. W. (1998). Influence of drainage connectivity, drainage area and regional species richness on fishes of the interior highlands in Arkansas. American Midland Naturalist, 1-19.

McClurg, S. E., Petty, J. T., Mazik, P. M., \& Clayton, J. L. (2007). Stream ecosystem response to limestone treatment in acid impacted watersheds of the Allegheny Plateau. Ecological Applications, 17(4), 1087-1104. 
Menendez, R., Clayton, J. L., \& Zurbuch, P. E. (1996). Chemical and fishery responses to mitigative liming of an acidic stream, Dogway Fork, West Virginia. Restoration Ecology, 4(3), 220-233.

Merovich, G. T., \& Petty, J. T. (2007). Interactive effects of multiple stressors and restoration priorities in a mined Appalachian watershed. Hydrobiologia, 575(1), 13-31.

Merovich, G.T., Petty, J.T., Strager, M.P., Fulton, J.B. (2013). Hierarchical classification of stream condition: a house-neighborhood framework for establishing conservation priorities in complex riverscapes. Freshwater Science, 32(3), 874-891.

Merovich, G. T., Stiles, J. M., Petty, J. T., Ziemkiewicz, P. F., \& Fulton, J. B. (2007). Water chemistry-based classification of streams and implications for restoring mined Appalachian watersheds. Environmental Toxicology and Chemistry, 26(7), 1361-1369.

Merriam, E. R., \& Petty, J. T. (2016). Under siege: Isolated tributaries are threatened by regionally impaired metacommunities. Science of The Total Environment, 560-561, 170178.

Merritt, R. W., Cummins, K. W., Resh, V. H., \& Batzer, D. P. (2008). Sampling aquatic insects: Collection devices, statistical considerations, and rearing procedures. An introduction to the aquatic insects of North America, 4, 15-37.

Oksanen, J.F., Guillaume Blanchet, Kindt, R., Legendre, P., Minchin, P.R., O’Hara, R.B., Simpson, G.L., Solymos, P., Henry, M., Stevens, H., Wagner, H. (2013) vegan: Community Ecology Package. R package version 2.0-10. R Foundation for Statistical Computing, Vienna, Austria. 
Palmer, M. A., Bernhardt, E. S., Allan, J. D., Lake, P. S., Alexander, G., Brooks, S., ... Sudduth, E. (2005). Standards for ecologically successful river restoration. Journal of Applied Ecology, 42, 208-217.

Palmer, M. A., Hondula, K. L., \& Koch, B. J. (2014). Ecological Restoration of Streams and Rivers: Shifting Strategies and Shifting Goals - annurev-ecolsys-120213-091935. Annu. Rev. Ecol. Evol. Syst, 45, 247-69.

Palmer, M. W., \& White, P. S. (1994). Scale dependence and the species-area relationship. The American Naturalist, 144(5), 717-740.

Parkyn, S. M., \& Smith, B. J. (2011). Dispersal constraints for stream invertebrates: setting realistic timescales for biodiversity restoration. Environmental management, 48(3), 602614.

Pavlick, M., Hansen, E., \& Christ, M. (2006). Watershed Based Plan for the Three Fork Creek watershed in the Tygart Valley River drainage, West Virginia. Downstream Strategies, Morgantown, $W V$.

Petty, J.T., Gutta, B., Herd, R., Fulton, J., Stiles, J., Strager, M., Svetlick, J., Ziemkiewicz, P. (2008). Identifying cost-effective restoration strategies in mining impacted West Virginia watersheds. America Society of Mining and Reclamation, 837-856.

Petty, J. T., Lamothe, P. J., \& Mazik, P. M. (2005). Spatial and seasonal dynamics of brook trout populations inhabiting a central Appalachian watershed. Transactions of the American Fisheries Society, 134(3), 572-587. 
Petty, J. T., \& Thorne, D. (2005). An ecologically based approach to identifying restoration priorities in an acid-impacted watershed. Restoration Ecology, 13(2), 348-357.

Pinder, M. J., \& Morgan, R. P. (1995). Interactions of pH and habitat on cyprinid distributions in Appalachian streams of Maryland. Transactions of the American Fisheries Society, 124(1), 94-102.

Poff, N. L., \& Allan, J. D. (1995). Functional organization of stream fish assemblages in relation to hydrological variability. Ecology, 76(2), 606-627.

Pond, G. J., Passmore, M. E., Borsuk, F. A., Reynolds, L., \& Rose, C. J. (2008). Downstream effects of mountaintop coal mining: comparing biological conditions using family-and genus-level macroinvertebrate bioassessment tools. Journal of the North American Benthological Society, 27(3), 717-737.

Pond, G.J., Bailey, J.E., Lowman, B.M., Whitman, M.J. (2013). Calibration and validation of a regionally and seasonally stratified macroinvertebrate index for West Virginia wadeable streams. Environmental Monitoring and Assessment, 185(2), 1515-1540.

Poplar-Jeffers, I. O., Petty, J. T., Anderson, J. T., Kite, S. J., Strager, M. P., \& Fortney, R. H. (2009). Culvert replacement and stream habitat restoration: implications from brook trout management in an Appalachian watershed, USA. Restoration Ecology, 17(3), 404-413.

Pusey BJ, Arthington AH, Read MG. (1993).Spatial and temporal variation in fish assemblage structure in the Mary River, south-eastern Queensland: the influence of habitat structure. Environmental Biology of Fishes, 37(4), 355-380.

Quinn, J. M., Croker, G. F., Smith, B. J., \& Bellingham, M. A. (2009). Integrated catchment 
management effects on flow, habitat, instream vegetation and macroinvertebrates in Waikato, New Zealand, hill-country streams. New Zealand Journal of Marine and Freshwater Research, 43(3), 775-802.

Robertson, B. A., \& Hutto, R. L. (2006). A framework for understanding ecological traps and an evaluation of existing evidence. Ecology, 87(5), 1075-1085.

Rosgen, D. (1998). The Reference Reach: A Blueprint for Natural Channel Design. In Engineering Approaches to Ecosystem Restoration (pp. 1009-1016). Reston, VA: American Society of Civil Engineers.

Rosgen DL. 2011. Natural channel design: fundamental concepts, assumptions, and methods. In Stream Restoration in Dynamic Fluvial Systems: Scientific Approaches, Analyses, and Tools, Geophys. Monogr. Ser. 194, ed. A Simon, SJ Bennett, JM Castro, pp. 6993. Washington, DC: Am. Geophys. Union

Simmons, K. R., \& Doyle, K. (1996). Limestone treatment of Whetstone Brook, Massachusetts. III. Changes in the invertebrate fauna. Restoration ecology, 4(3), 284-292.

Smucker, N. J., \& Detenbeck, N. E. (2014). Meta-Analysis of Lost Ecosystem Attributes in Urban Streams and the Effectiveness of Out-of-Channel Management Practices. Restoration Ecology, 22(6), 741-748.

Stoddard, J. L., Herlihy, A. T., Hill, B. H., Hughes, R. M., Kaufmann, P. R., Klemm, D. J., ... \& Olsen, A. R. (2006). Mid-Atlantic integrated assessment (MAIA)—state of the flowing waters report. Algae, 31, 41.

Stoll, S., Sundermann, A., Lorenz, A. W., Kail, J., \& Haase, P. (2013). Small and impoverished 
regional species pools constrain colonisation of restored river reaches by fishes. Freshwater Biology, 58(4), 664-674.

Stoll, S., Kail, J., Lorenz, A. W., Sundermann, A., \& Haase, P. (2014). The importance of the regional species pool, ecological species traits and local habitat conditions for the colonization of restored river reaches by fish. PloS one, 9(1), e84741.

Sundermann, A., Stoll, S., \& Haase, P. (2011). River restoration success depends on the species pool of the immediate surroundings. Ecological Applications, 21(6), 1962-1971.

USACE (US Army Corps of Engineers) (1997). Tygart Three-Fork watershed ecosystem restoration study: reconnaissance report. June, 1997.

USEPA (US Environmental Protection Agency). Office of Wetlands, Oceans and Watersheds. Office of Research and Development. (2016). National Rivers and Streams Assessment 2008-2009. US Environmental Protection Agency, Washington D.C., USA.

Violin, C. R., Cada, P., Sudduth, E. B., Hassett, B. A., Penrose, D. L., \& Bernhardt, E. S. (2011). Effects of urbanization and urban stream restoration on the physical and biological structure of stream ecosystems. Ecological Applications, 21(6), 1932-1949.

Watson, A.S., Merovich, G.T., Petty, J.T., Gutta, J.B. (2017) Evaluating expected outcomes of acid remediation in an intensively mined Appalachian watershed. Environmental Monitoring and Assessment, 189(7), 339.

Walsh, C. J., Fletcher, T. D., \& Ladson, A. R. (2005). Stream restoration in urban catchments through redesigning stormwater systems: looking to the catchment to save the stream. Benthol. Soc, 24(3), 690-705. 
Weatherley, N. S., Rutt, G. P., Thomas, S. P., \& Ormerod, S. J. (1991). Liming acid streams: aluminium toxicity to fish in mixing zones. Water, Air, and Soil Pollution, 55(3-4), 345353.

Welsh, S. A., \& Perry, S. A. (1997). Acidification and fish ovvurrence in the upper Cheat River Drainage, West Virginia 1. JAWRA Journal of the American Water Resources Association, 33(2), 423-429.

WVDEP (West Virginia Department of Environmental Protection). 2013. Benthic invertebrate sampling, processing, and analysis standard operating procedures. West Virginia Department of Environmental Protection, Charleston, West Virginia, USA.

WVDEP (West Virginia Department of Environmental Protection). 2013. Three Fork Creek Watershed Restoration Project. West Virginia Department of Environmental Protection, Charleston, West Virginia, USA.

WVWRI (West Virginia Water Research Institute), National Mine Reclamation Center, Watershed Technical Assistance Center, West Virginia University. (2007). Abram Creek watershed restoration plan. West Virginia University, Morgantown, West Virginia, USA.

Ziemkiewicz, P. F., Skousen, J. G., Brant, D. L., Sterner, P. L., \& Lovett, R. J. (1997). Acid mine drainage treatment with armored limestone in open limestone channels. Journal of Environmental Quality, 26(4), 1017-1024. 
Figures

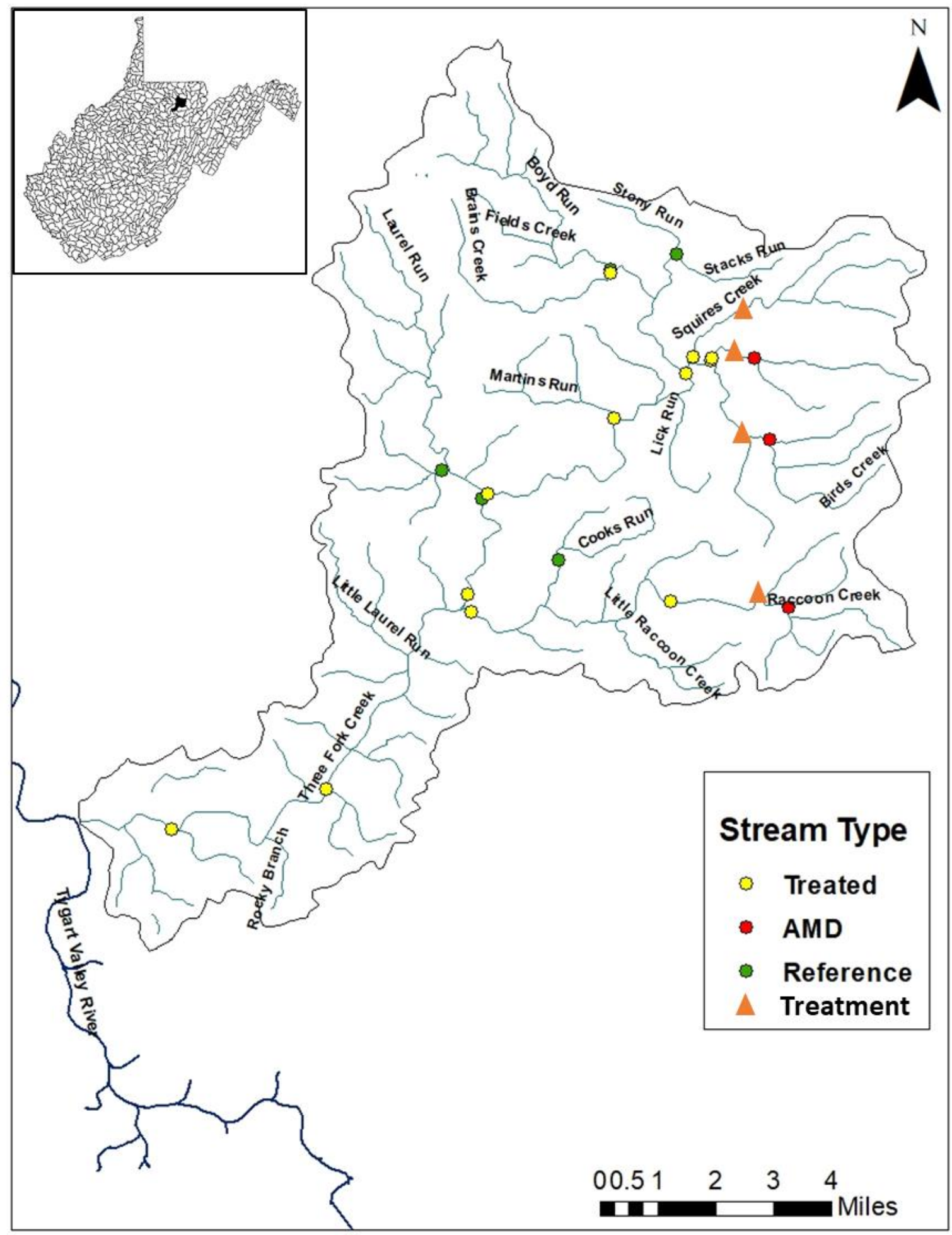

Figure 1. Map of Three Forks Creek, West Virginia with site locations, site types (i.e. treated, AMD, and reference), and treatment locations. 


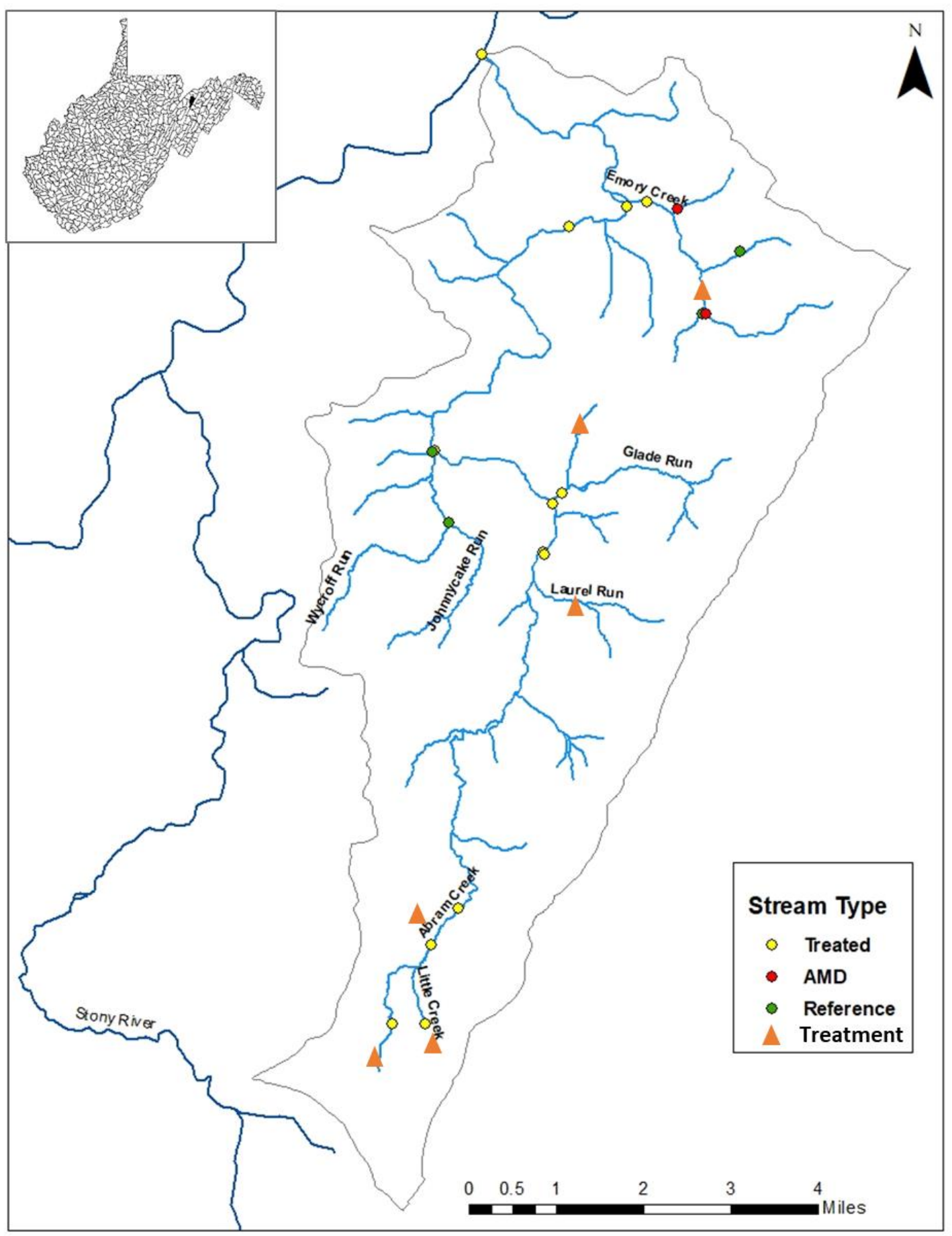

Figure 2. Map of Abram Creek, West Virginia with site locations, site types (i.e. treated, AMD, and reference), and treatment locations. 

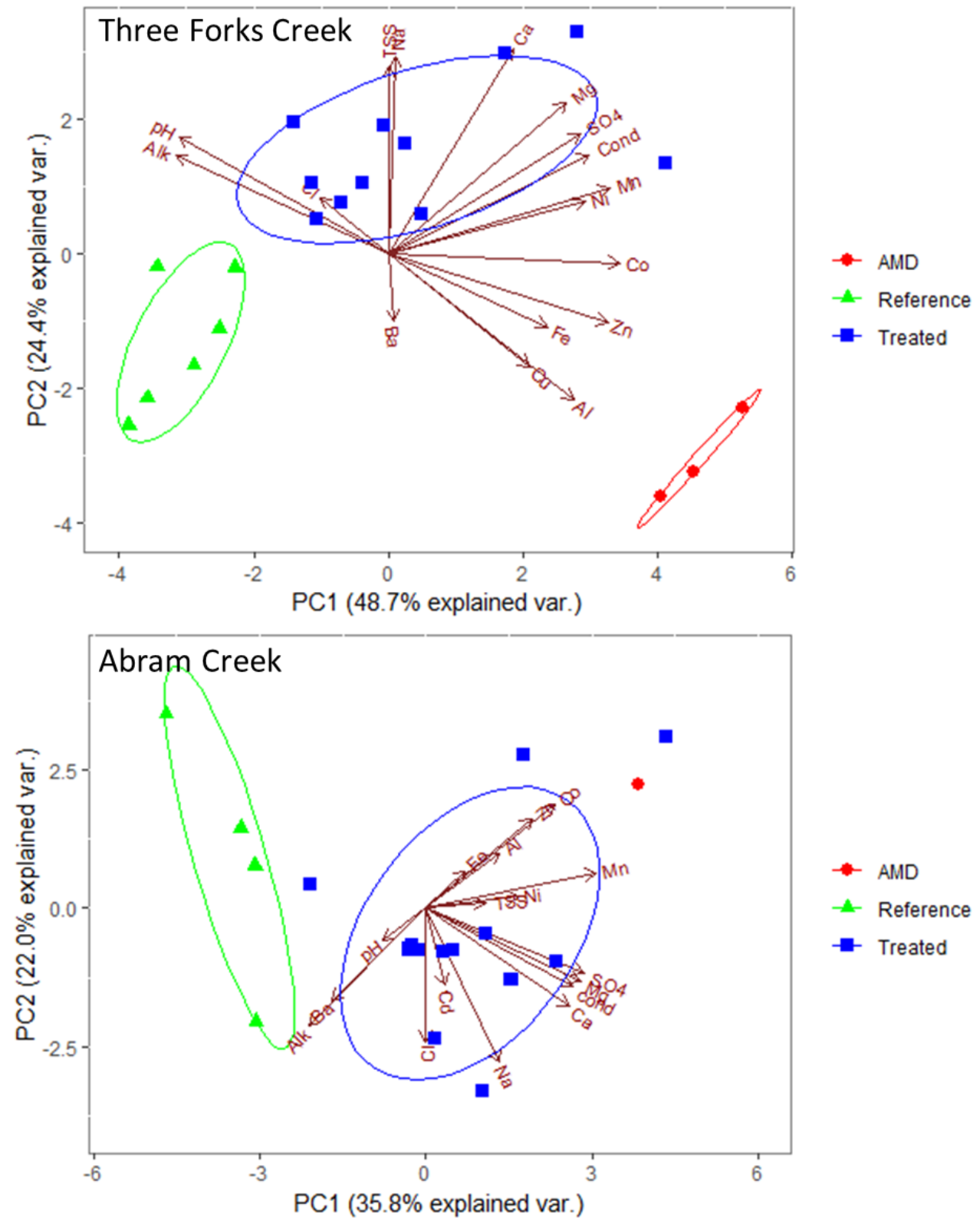

Figure 3. Scatter plots of principal components (PC) 1 and 2 scores for every water chemistry sample in Three Forks Creek and Abram Creek. Points are colored and shaped by site types (red=AMD, green=reference, blue=treated). Vectors show the correlations of each chemical parameter by both direction and degree of correlation (i.e. length of vectors). 

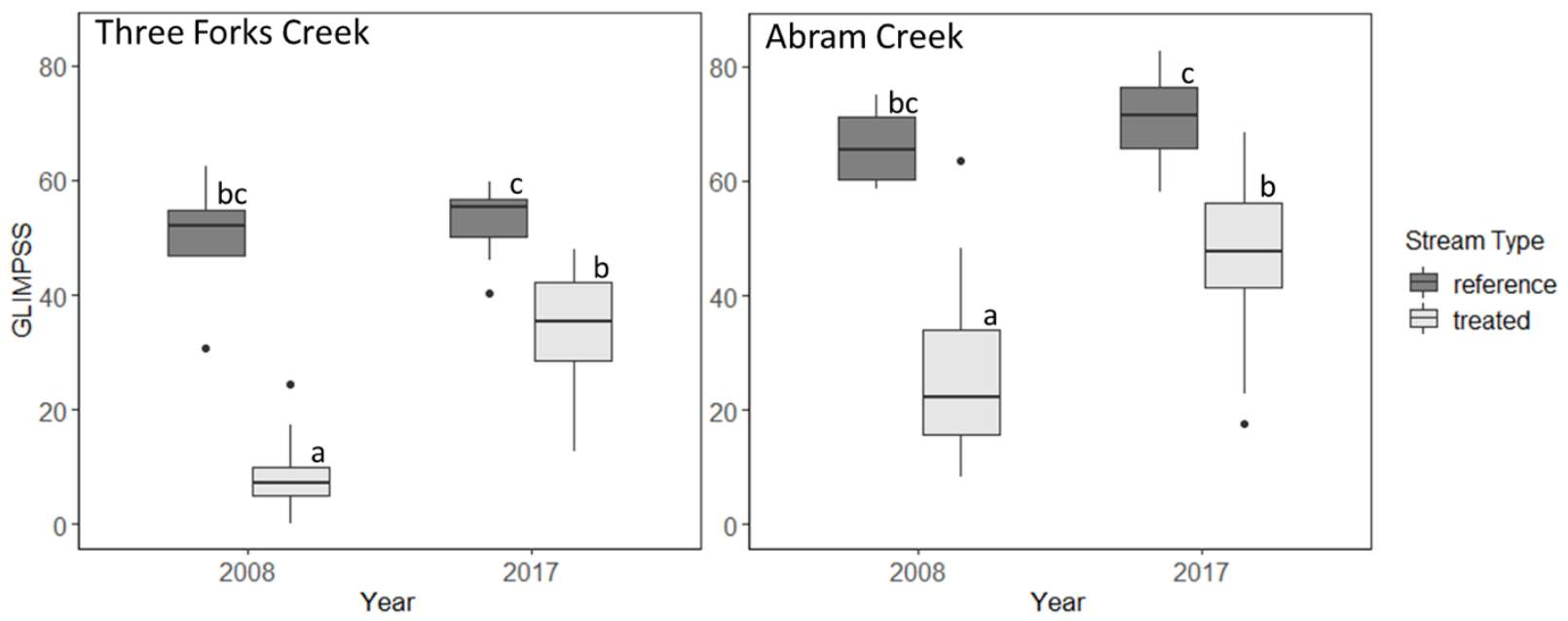

Figure 4. Genus-level index of most probable stream status (GLIMPSS) scores pre- (2008) and post-restoration (2017) for the reference and treated sites of Three Fork Creek and Abram Creek. Lowercase letters show significant differences as identified by one-way ANOVA followed by Tukey post tests (Three Forks) or pairwise t-tests (Abram) between scores of treatment types within each plot. Reference GLIMPSS scores seen for Abram Creek in 2008 were taken from a survey in 2013. 

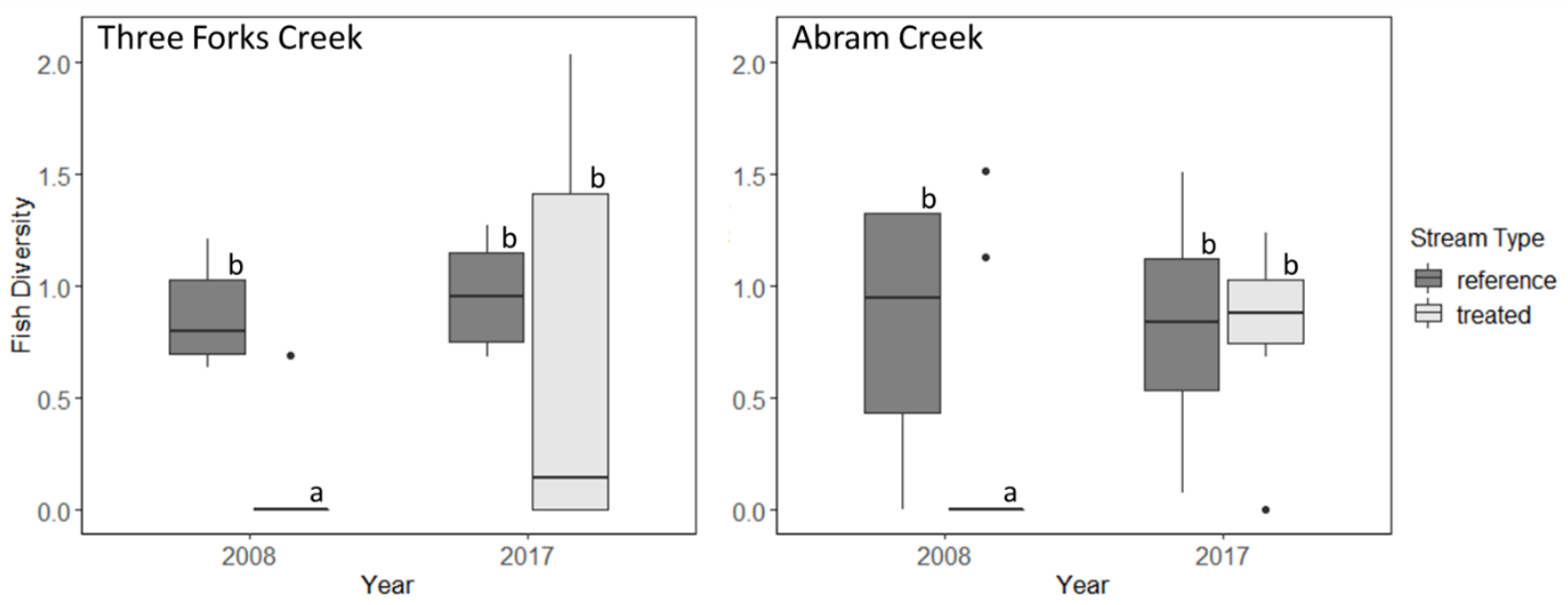

Figure 5. Fish diversity scores for the reference and treated sites of Three Forks Creek and Abram Creek pre- (2008) and post-restoration (2017). Lowercase letters denote significant differences as identified by repeated measures ANOVA and Tukey post-hoc tests of scores within and between treatment types in each plot. 


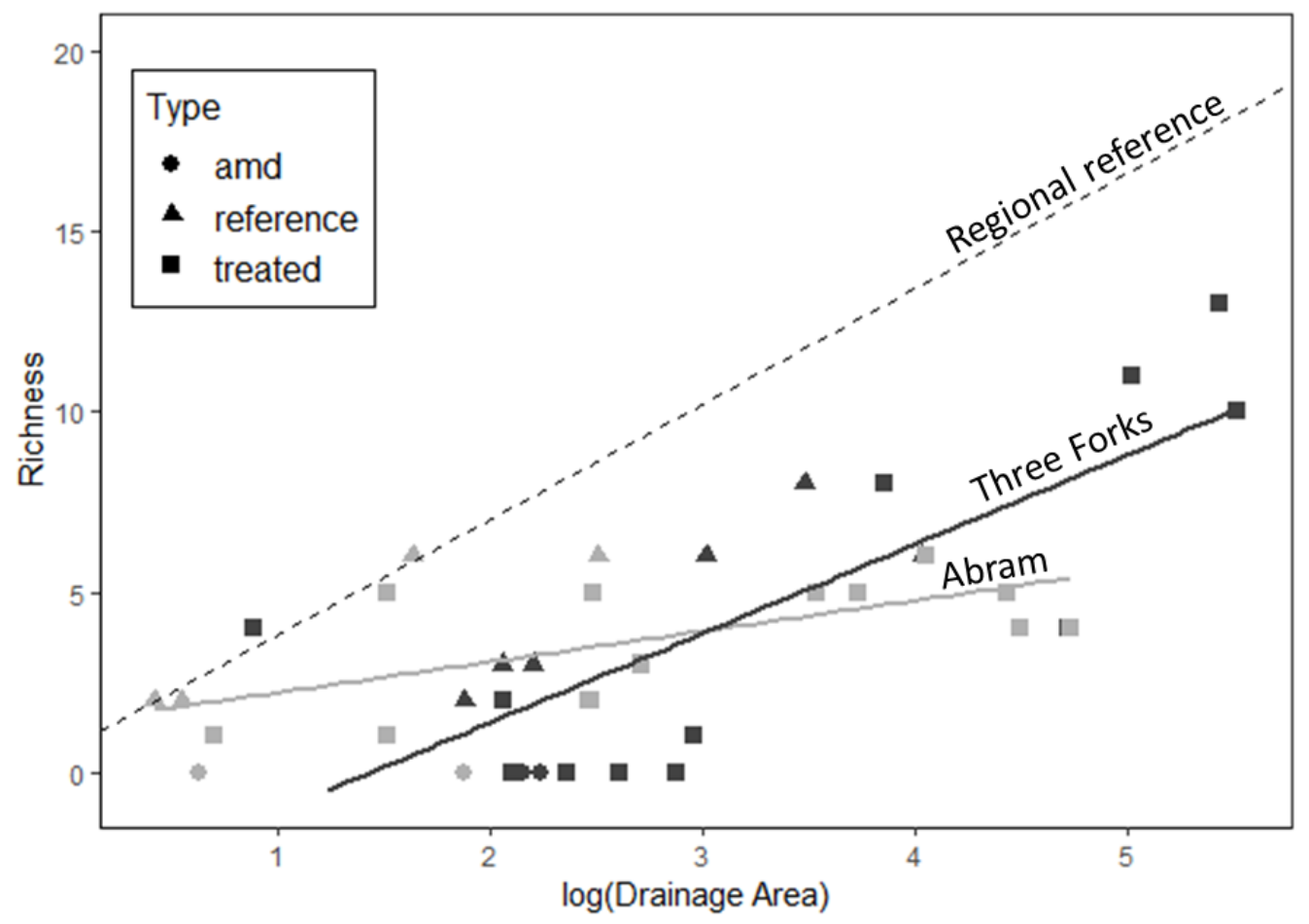

Figure 6. Plot of the relationship between fish species richness and log drainage area for Three Forks Creek (dark solid line), Abram Creek (light solid line) and regional reference conditions (dashed line). Stream types are indicated by shape for AMD, reference, and treated streams and color indicates the watershed the points belong to (i.e. dark grey $=$ Three Forks Creek, light grey= Abram Creek). 


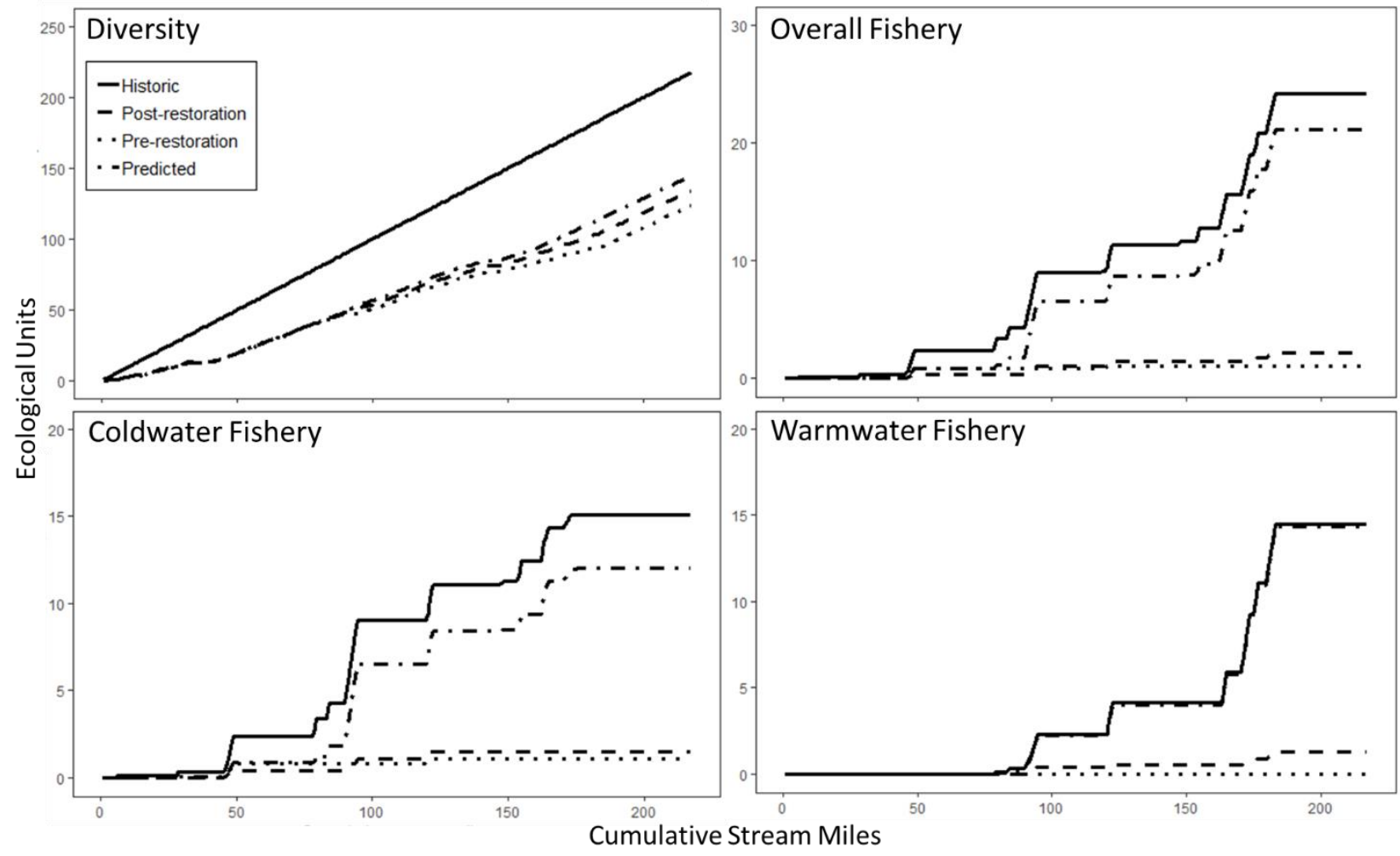

Figure 7. Ecological Units in Three Forks Creek for diversity, overall fishery, cold-water fishery, and warm-water fishery. Diversity units in this figure represent macroinvertebrate diversity. Overall fishery units represent a combination of trout and warm-water fisheries. 

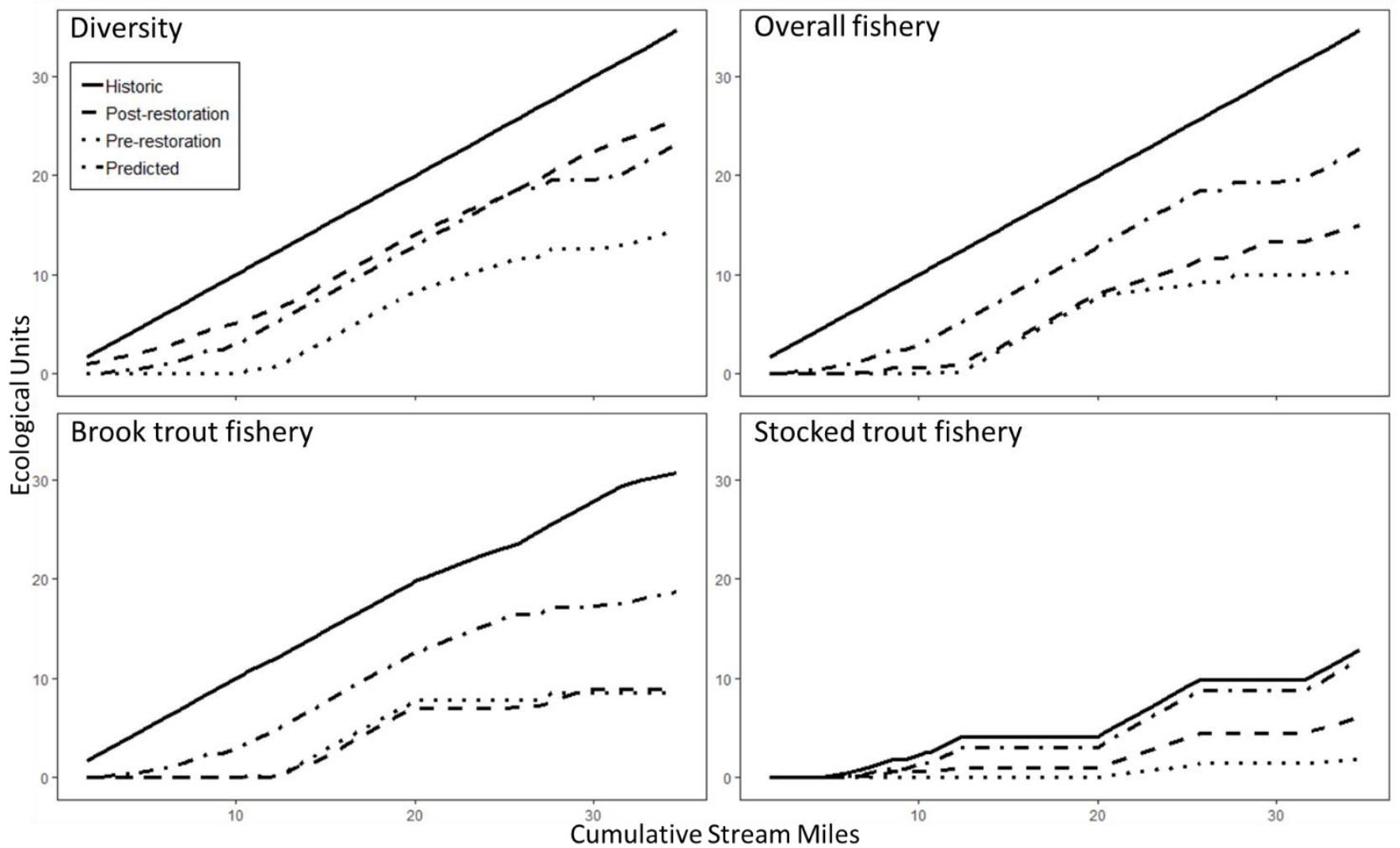

Figure 8. Ecological Units (EU) in Abram Creek for diversity, brook trout, stocked trout, and overall fishery. Diversity units in this figure represent macroinvertebrate diversity. Overall fishery units represent a combination of native brook trout and stocked trout. 

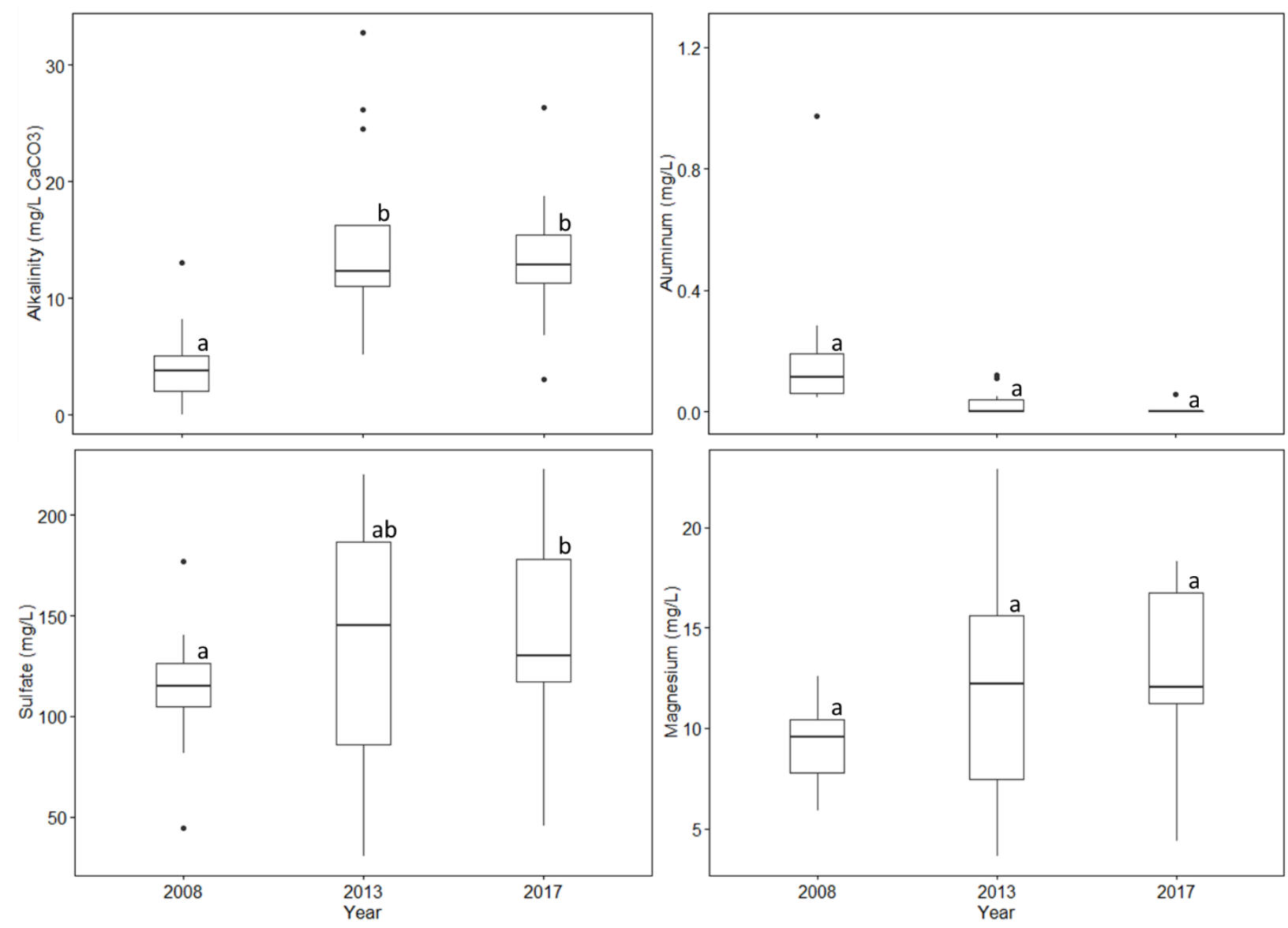

Figure 9. Concentrations of alkalinity ( $\mathrm{CaCO} 3 \mathrm{mg} / \mathrm{L}$ equivalents), aluminum $(\mathrm{mg} / \mathrm{L})$, magnesium $(\mathrm{mg} / \mathrm{L})$, and sulfate $(\mathrm{mg} / \mathrm{L})$ in treated sites of Abram Creek in 2008 (pre-restoration), 2013 (postrestoration), and 2017 (post-restoration). Lowercase letters denote significant differences indicated by one-way ANOVA and t-tests between concentrations of each chemical within treated sites. 


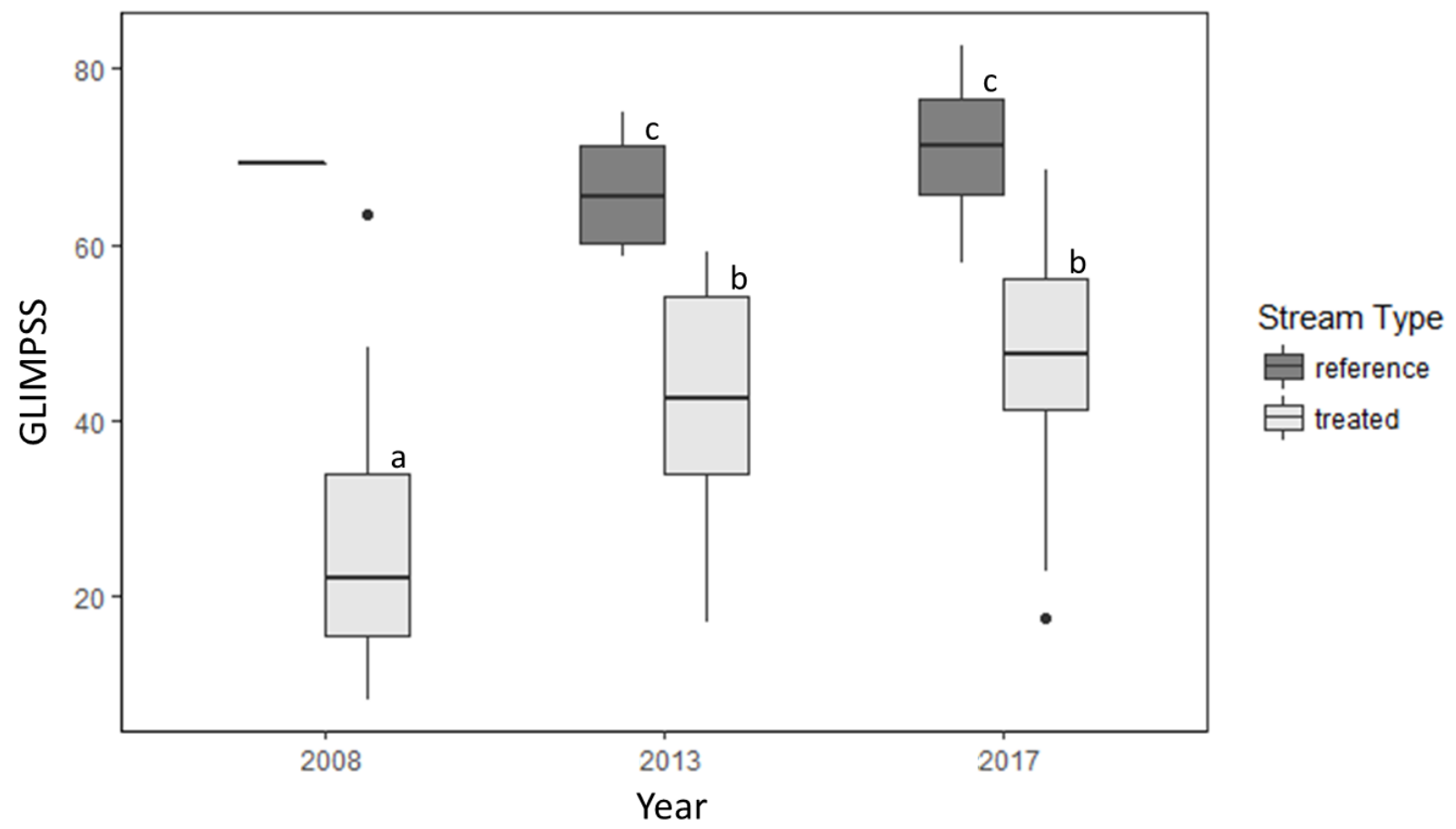

Figure 10. GLIMPSS scores for treated streams and reference streams in Abram Creek for sites sampled in 2008, 2013, and 2014. Lowercase letters show significant or non-significant differences between scores of treatment types. 


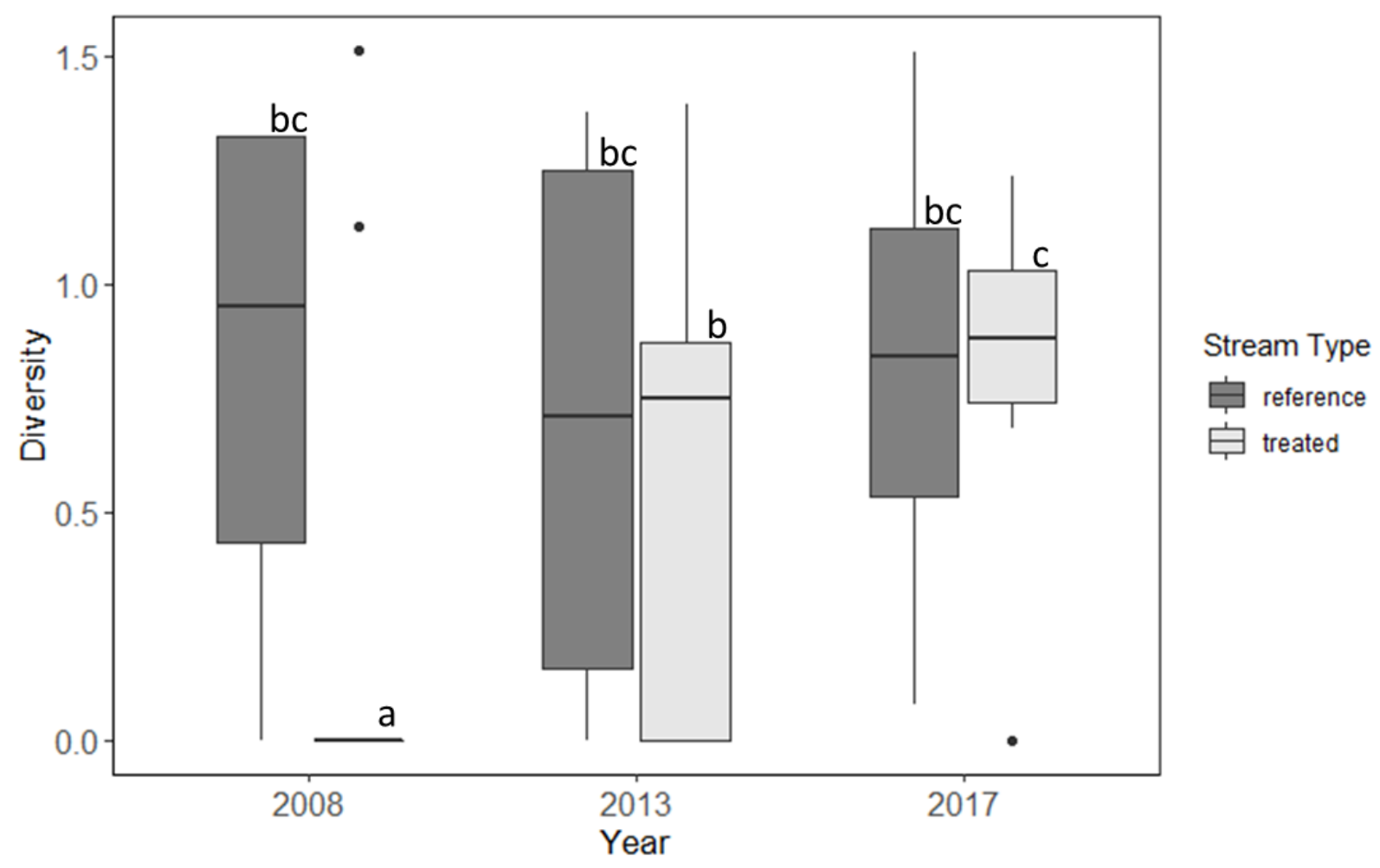

Figure 11. Shannon diversity of fish communities in treated and reference streams in Abram Creek. Lowercase letters show significant or non-significant differences between scores of treatment types. 


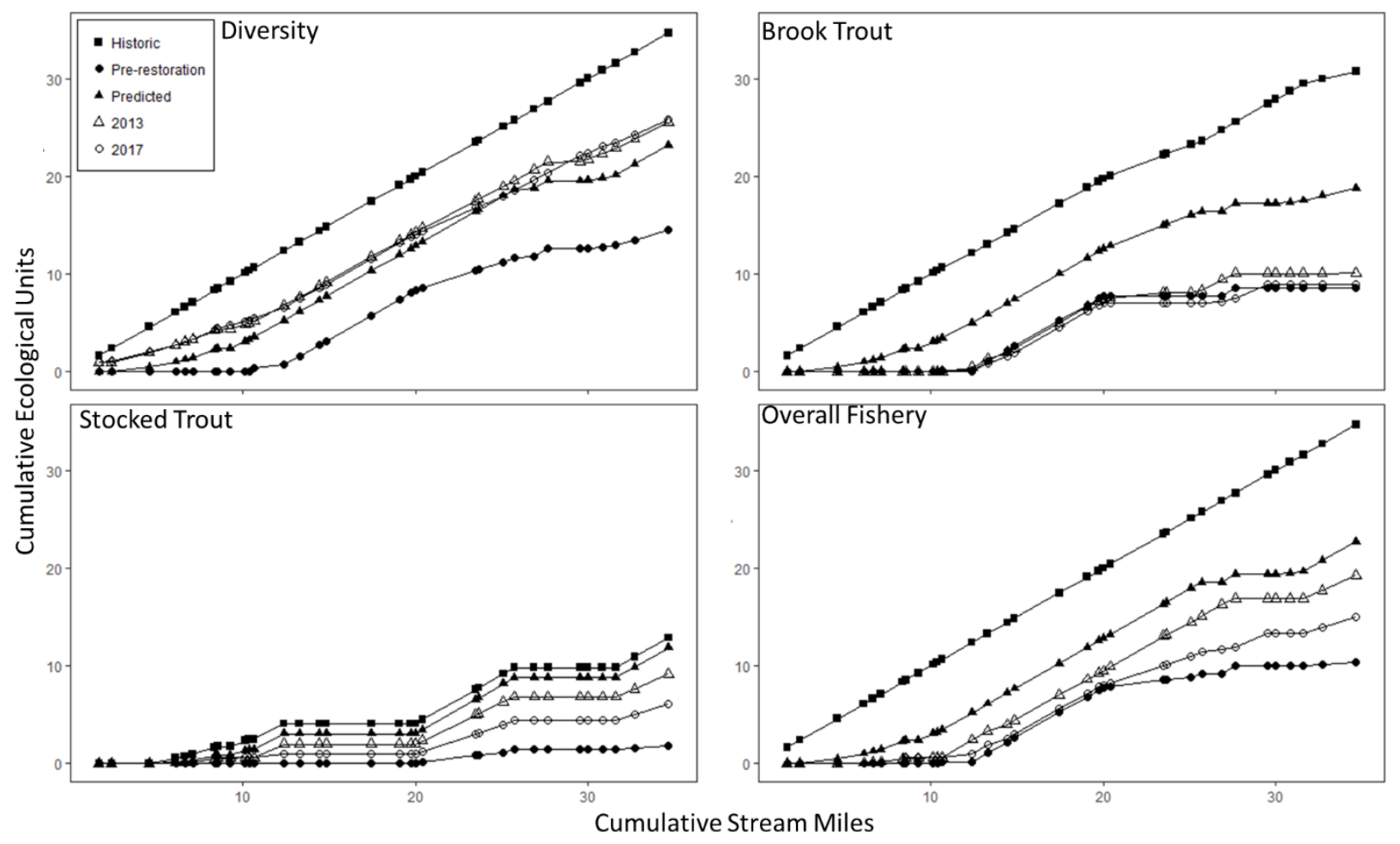

Figure 12. Ecological Units (EU) in Abram Creek for diversity, brook trout, stocked trout, and overall fishery. This figure includes both 2013 and 2017 data. Diversity units in this figure represent macroinvertebrate diversity. Overall fishery units represent a combination of native brook trout and stocked trout. 


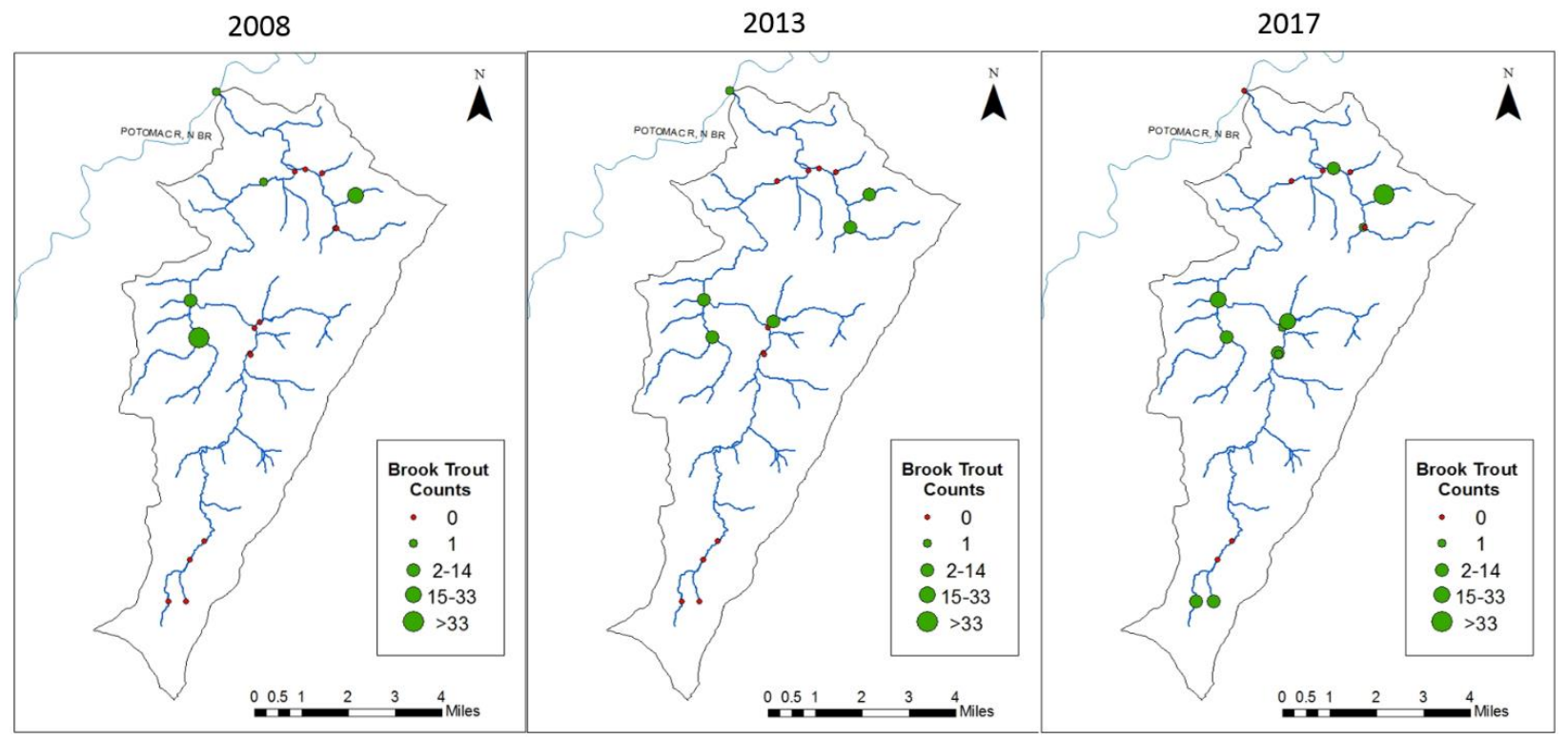

Figure 13. Distribution of brook trout throughout the Abram Creek watershed. Symbols are site locations and sized based on the number of brook trout found at each site. Red dots indicate no brook trout were found at that sample location. 


\section{Tables}

Table 1. Site names, GPS coordinates, drainage area in $\mathrm{km}^{2}$, and stream type of all sites in the Three Forks Creek watershed.

\begin{tabular}{|c|c|c|c|c|c|}
\hline Site & Watershed & Latitude & Longitude & Drainage Area $\left(\mathrm{km}^{2}\right)$ & Stream Type \\
\hline Three Forks at Mouth & Three Forks Creek & 39.33667 & -79.99295 & 250.01 & Treated \\
\hline Raccoon at Mouth & Three Forks Creek & 39.39035 & -79.89546 & 47.63 & Treated \\
\hline Upper Raccoon Creek & Three Forks Creek & 39.39242 & -79.83082 & 17.79 & Treated \\
\hline Raccoon Headwaters & Three Forks Creek & 39.39043 & -79.79285 & 9.41 & AMD \\
\hline Upper Bird Creek & Three Forks Creek & 39.43243 & -79.7983 & 8.23 & Treated \\
\hline Bird Creek Headwaters & Three Forks Creek & 39.46304 & -79.90289 & 8.67 & AMD \\
\hline Brains Creek & Three Forks Creek & 39.47491 & -79.84912 & 9.09 & AMD \\
\hline Boyd Creek & Three Forks Creek & 39.47581 & -79.84896 & 20.47 & Reference \\
\hline Squires Creek & Three Forks Creek & 39.45360 & -79.82261 & 13.65 & Treated \\
\hline Birds Creek & Three Forks Creek & 39.45262 & -79.81676 & 19.24 & Treated \\
\hline Fields Creek & Three Forks Creek & 39.44936 & -79.82512 & 56.65 & Reference \\
\hline Stacks Creek & Three Forks Creek & 39.47921 & -79.82744 & 2.43 & Treated \\
\hline Three Forks above Laurel & Three Forks Creek & 39.41986 & -79.88952 & 113.13 & Treated \\
\hline Laurel Creek & Three Forks Creek & 39.41874 & -79.89161 & 32.64 & Reference \\
\hline Three Forks at Three Forks Bridge & Three Forks Creek & 39.43833 & -79.84832 & 7.9 & Treated \\
\hline Three Forks above Raccoon & Three Forks Creek & 39.39466 & -79.89658 & 152.22 & Treated \\
\hline Cooks Run & Three Forks Creek & 39.40298 & -79.86691 & 6.57 & Reference \\
\hline Unnamed Tributary Laurel Creek & Three Forks Creek & 39.42592 & -79.90414 & 7.85 & Reference \\
\hline Unnamed Tributary Birds Creek at 58 & Three Forks Creek & 39.45327 & -79.81639 & 10.61 & Treated \\
\hline Three Forks Creek in Thornton & Three Forks Creek & 39.34653 & -79.94287 & 229.45 & Treated \\
\hline
\end{tabular}


Table 2. Site names, GPS coordinates, drainage area in $\mathrm{km}^{2}$, and stream type of all sites in the Abram Creek watershed.

\begin{tabular}{llcccl}
\hline Site & Watershed & Latitude & Longitude & Drainage Area $\left(\mathrm{km}^{2}\right)$ & Stream Type \\
\hline Abram Creek at Mouth & Abram Creek & 39.37938 & -79.20199 & 113.52 & Treated \\
Abram Creek above Emory & Abram Creek & 39.35369 & -79.17154 & 89.58 & Treated \\
Emory Creek at Mouth & Abram Creek & 39.35429 & -79.16722 & 15.06 & Treated \\
Unnamed Tributary 2 Emory Creek & Abram Creek & 39.34580 & -79.14743 & 1.74 & Reference \\
Unnamed Tributary 1 Emory Creek & Abram Creek & 39.35313 & -79.16073 & 1.87 & AMD \\
Emory Creek Headwater Right Fork & Abram Creek & 39.33565 & -79.15599 & 1.53 & Reference \\
Emory Creek Headwater Left Fork & Abram Creek & 39.33565 & -79.15524 & 6.55 & AMD \\
Abram Creek at Laytons & Abram Creek & 39.35058 & -79.18403 & 84.77 & Treated \\
Johnnycake Run at Mouth & Abram Creek & 39.31358 & -79.21424 & 12.31 & Reference \\
Upper Johnnycake Run & Abram Creek & 39.30171 & -79.21109 & 5.14 & Reference \\
Abram Creek above Johnnycake & Abram Creek & 39.31370 & -79.21385 & 57.67 & Treated \\
Glade Run at Mouth & Abram Creek & 39.30629 & -79.18667 & 12.06 & Treated \\
Abram Creek above Glade & Abram Creek & 39.30453 & -79.18884 & 41.98 & Treated \\
Laurel Run at Mouth & Abram Creek & 39.29037 & -79.19212 & 4.58 & Treated \\
Abram Creek above Laurel & Abram Creek & 39.29053 & -79.19427 & 34.35 & Treated \\
Abram Creek at Vindex & Abram Creek & 39.24735 & -79.21129 & 11.85 & Treated \\
Abram Creek at CR 42 & Abram Creek & 39.23161 & -79.21660 & 8.56 & Treated \\
Little Creek & Abram Creek & 39.21851 & -79.21824 & 2.02 & Treated \\
Abram Creek Headwaters Right Fork & Abram Creek & 39.21855 & -79.22520 & 4.57 & Treated \\
\hline
\end{tabular}


Table 3. Chemical summary table of water chemistry samples in treated sites pre- (2008) and post-restoration (2017) in Three Forks Creek. Mean concentrations and standard deviations (SD) of each selected chemical parameter among all treated sites is listed.

\begin{tabular}{l|c|c|c|c} 
& \multicolumn{2}{c}{ Pre-Restoration } & \multicolumn{2}{c}{ Post-Restoration } \\
Three Fork Creek & \multicolumn{1}{c}{ Mean } & \multicolumn{1}{c}{ SD } & \multicolumn{1}{c}{ Mean } & SD \\
\hline Alkalinity $\left(\mathrm{mg} / \mathrm{L} \mathrm{CaCO}_{3}\right)$ & 1.09 & 0.99 & 12.80 & 7.57 \\
$\mathrm{SO}_{4}{ }^{2-}(\mathrm{mg} / \mathrm{L})$ & 514.60 & 136.81 & 137.63 & 49.72 \\
$\mathrm{Al}(\mathrm{mg} / \mathrm{L})$ & 9.85 & 6.71 & 0.10 & 0.35 \\
$\mathrm{Fe}(\mathrm{mg} / \mathrm{L})$ & 2.06 & 4.53 & 0.22 & 0.57 \\
$\mathrm{Mn}(\mathrm{mg} / \mathrm{L})$ & 2.78 & 1.01 & 0.51 & 0.28 \\
$\mathrm{Mg}(\mathrm{mg} / \mathrm{L})$ & 26.08 & 7.64 & 8.42 & 2.71 \\
Conductivity (uS/cm) & 313 & 150 & 309 & 63 \\
Total Dissolved Solids $(\mathrm{mg} / \mathrm{L})$ & 12.2 & 15.6 & 14.4 & 11.3
\end{tabular}


Table 4. Chemical summary table of water chemistry samples in treated sites pre- (2008) and post-restoration (2017) in Abram Creek. Mean concentrations and standard deviations (SD) of each selected chemical parameter among all treated sites is listed.

\begin{tabular}{|c|c|c|c|c|}
\hline \multirow[b]{2}{*}{ Abram Creek } & \multicolumn{2}{|c|}{ Pre-Restoration } & \multicolumn{2}{|c|}{ Post-Restoration } \\
\hline & Mean & SD & Mean & SD \\
\hline Alkalinity $\left(\mathrm{mg} / \mathrm{L} \mathrm{CaCO}_{3}\right)$ & 10.81 & 15.55 & 13.38 & 5.61 \\
\hline $\mathrm{SO}_{4}^{2-}(\mathrm{mg} / \mathrm{L})$ & 310.15 & 103.08 & 135.66 & 48.32 \\
\hline $\mathrm{Al}(\mathrm{mg} / \mathrm{L})$ & 0.68 & 1.19 & 0.00 & 0.02 \\
\hline $\mathrm{Fe}(\mathrm{mg} / \mathrm{L})$ & 0.46 & 0.68 & 0.10 & 0.20 \\
\hline $\mathrm{Mn}(\mathrm{mg} / \mathrm{L})$ & 2.25 & 1.82 & 0.85 & 0.73 \\
\hline $\mathrm{Mg}(\mathrm{mg} / \mathrm{L})$ & 25.35 & 6.39 & 12.89 & 4.23 \\
\hline Conductivity (uS/cm) & 291 & 39 & 326 & 110 \\
\hline Total Dissolved Solids (mg/L) & 5.8 & 7.9 & 6.0 & 5.1 \\
\hline
\end{tabular}


Table 5. Factor loadings of each chemical parameter analyzed post-restoration (2017) for principal components (PC) 1 and 2 in Three Forks Creek.

\begin{tabular}{l|c|c} 
& PCA1 & PCA2 \\
\hline $\mathrm{pH}$ & -0.86 & 0.48 \\
Conductivity & 0.83 & 0.41 \\
Alkalinity & -0.88 & 0.40 \\
$\mathrm{SO} 4$ & 0.79 & 0.49 \\
$\mathrm{Cl}$ & -0.28 & 0.23 \\
$\mathrm{Al}$ & 0.77 & -0.60 \\
$\mathrm{Ba}$ & 0.02 & -0.28 \\
$\mathrm{Ca}$ & 0.51 & 0.84 \\
$\mathrm{Cu}$ & 0.58 & -0.46 \\
$\mathrm{Co}$ & 0.95 & -0.04 \\
$\mathrm{Fe}$ & 0.66 & -0.30 \\
$\mathrm{Mg}$ & 0.73 & 0.62 \\
$\mathrm{Mn}$ & 0.91 & 0.27 \\
$\mathrm{Na}$ & 0.03 & 0.81 \\
$\mathrm{Ni}$ & 0.81 & 0.22 \\
$\mathrm{Zn}$ & 0.90 & -0.28 \\
$\mathrm{TSS}$ & 0.00 & 0.77 \\
& &
\end{tabular}


Table 6. Factor loadings of each chemical parameter analyzed post-restoration (2017) for principal components (PC) 1,2 and 3 in Abram Creek.

\begin{tabular}{l|c|c|c} 
& PCA1 & PCA2 & PCA3 \\
\hline $\mathrm{pH}$ & -0.26 & -0.13 & 0.40 \\
Conductivity & 0.75 & -0.31 & 0.31 \\
Alkalinity & -0.53 & -0.51 & -0.27 \\
$\mathrm{SO} 4$ & 0.83 & -0.32 & 0.33 \\
$\mathrm{Cl}$ & 0.04 & -0.73 & -0.51 \\
$\mathrm{Al}$ & 0.43 & 0.25 & -0.36 \\
$\mathrm{Ba}$ & -0.54 & -0.50 & -0.27 \\
$\mathrm{Ca}$ & 0.72 & -0.50 & 0.29 \\
$\mathrm{Cd}$ & 0.09 & -0.46 & -0.32 \\
$\mathrm{Co}$ & 0.76 & 0.50 & -0.32 \\
$\mathrm{Fe}$ & 0.26 & 0.16 & -0.69 \\
$\mathrm{Mg}$ & 0.79 & -0.39 & 0.35 \\
$\mathrm{Mn}$ & 0.92 & 0.25 & -0.11 \\
$\mathrm{Na}$ & 0.30 & -0.91 & -0.13 \\
$\mathrm{Ni}$ & 0.50 & 0.00 & 0.08 \\
$\mathrm{Zn}$ & 0.58 & 0.44 & 0.17 \\
$\mathrm{TSS}$ & 0.25 & -0.03 & -0.46 \\
& & &
\end{tabular}


Table 7. GLIMPSS scores for each site sampled in Three Forks Creek for the 2008 (prerestoration) and 2017 (post-restoration) sampling years.

\begin{tabular}{ll|rr} 
& & \multicolumn{2}{|c}{ GLIMPSS } \\
\hline Site & Type & 2008 & 2017 \\
\hline Three Forks at Mouth & treated & 1.83 & 46.08 \\
Three Forks at Thornton & treated & 24.35 & 41.96 \\
Three Forks above Raccoon & treated & 17.28 & 36.54 \\
Three Forks above Laurel & treated & 7.01 & 47.82 \\
Three Forks at Three Forks Bridge & treated & 8.92 & 28.06 \\
Raccoon at Mouth & treated & 10.42 & 42.32 \\
Stacks Creek & reference & - & 40.29 \\
Birds Creek & treated & 7.44 & 24.64 \\
Unnamed Tributary Birds Creek at 58 & treated & 5.14 & 30.16 \\
Birds Creek Headwaters & AMD & 0.00 & 30.37 \\
Fields Creek & reference & 52.28 & 54.24 \\
Laurel Creek & reference & 62.31 & 56.03 \\
Upper Bird Creek & AMD & 0.00 & 10.33 \\
Brains Creek & treated & 30.79 & 46.04 \\
Cooks Creek & reference & - & 55.27 \\
Upper Raccoon Creek & treated & 52.05 & 34.20 \\
Squires Creek & treated & 0.00 & 12.81 \\
Raccoon Headwaters & AMD & 2.10 & 4.60 \\
Boyd Creek & reference & 5.00 & 57.21 \\
Unnamed Tributary Laurel Creek & reference & - & 59.64
\end{tabular}


Table 8. GLIMPSS scores for each site sampled in Abram Creek for the 2008 (pre-restoration), 2013 (post-restoration) and 2017 (post-restoration) sampling years.

\begin{tabular}{ll|rrr} 
& & \multicolumn{3}{|c}{ GLIMPSS } \\
\hline Site & Type & 2008 & 2013 & 2017 \\
\hline Abram Creek at Mouth & treated & 34.64 & 57.05 & 60.13 \\
Emory Creek at Mouth & treated & 28.06 & 41.07 & 43.27 \\
Abram Creek above Emory & treated & 48.24 & 55.07 & 68.52 \\
Abram Creek at Laytons & treated & 34.06 & 52.34 & 55.72 \\
Johnnycake at Mouth & reference & 69.31 & 74.98 & 68.30 \\
Glade Run at Mouth & treated & 63.39 & 59.13 & 66.05 \\
Abram Creek above Glade & treated & 23.84 & 33.88 & 43.39 \\
Laurel Run at Mouth & treated & 13.25 & 16.95 & 35.11 \\
Abram Creek at Vindex & treated & 12.59 & 35.76 & 17.67 \\
Abram Creek at CR 42 & treated & 15.79 & 26.08 & 49.89 \\
Little Creek & treated & 8.36 & 20.2 & 22.74 \\
Abram Creek Headwaters Right Fork & treated & 15.61 & 42.63 & 41.38 \\
Unnamed Tributary 1 Emory Creek & AMD & - & - & 56.09 \\
Unnamed Tributary 2 Emory Creek & reference & - & 60.83 & 58.00 \\
Emory Creek Headwater Left Fork & AMD & - & 23.02 & 62.82 \\
Emory Creek Headwater Right Fork & reference & - & 58.54 & 74.35 \\
Upper Johnnycake Run & reference & - & 69.84 & 82.70 \\
Abram Creek above Johnnycake & treated & 21.39 & 54.06 & 47.55 \\
Abram Creek above Laurel & treated & 22.22 & 45.31 & 56.22
\end{tabular}


Table 9. Fish diversity for each site sampled in Three Forks Creek for the 2008 (pre-restoration) and 2017 (post-restoration) sampling years.

\begin{tabular}{ll|rr} 
& & \multicolumn{2}{|c}{ Fish Diversity } \\
\hline Site & Type & 2008 & 2017 \\
\hline Three Forks at Mouth & treated & 0.0000 & 1.7790 \\
Raccoon at Mouth & treated & 0.0000 & 1.0537 \\
Upper Raccoon Creek & treated & 0.0000 & 0.0000 \\
Raccoon Headwaters & AMD & 0.0000 & 0.0000 \\
Upper Bird Creek & AMD & 0.0000 & 0.0000 \\
Bird Creek Headwaters & AMD & 0.0000 & 0.0000 \\
Brains Creek & treated & 0.6365 & 0.7299 \\
Boyd Creek & reference & 1.2143 & 1.2727 \\
Squires Creek & treated & 0.0000 & 0.0000 \\
Birds Creek & treated & 0.0000 & 0.0000 \\
Fields Creek & reference & 0.6894 & 0.8387 \\
Stacks Creek & reference & 0.7268 & 0.8256 \\
Three Forks above Laurel & treated & 0.0000 & 0.1467 \\
Laurel Creek & reference & 1.0841 & 1.1738 \\
Three Forks at Three Forks Bridge & treated & 0.0000 & 0.0191 \\
Three Forks above Raccoon & treated & 0.0000 & 1.9787 \\
Cooks Run & reference & 0.6910 & 0.6849 \\
Unnamed Tributary Laurel Creek & reference & 0.8681 & 1.0862 \\
Unnamed Tributary Bird Creek at 58 & treated & 0.0000 & 0.0000 \\
Three Forks Creek in Thornton & treated & 0.0000 & 2.0364
\end{tabular}


Table 10. Fish diversity for each site sampled in Abram Creek for the 2008 (pre-restoration), 2013 (post-restoration) and 2017 (post-restoration) sampling years.

\begin{tabular}{ll|rrr} 
& & \multicolumn{3}{|c}{ Fish Diversity } \\
\hline Site & Type & 2008 & 2013 & 2017 \\
\hline Abram Creek above Emory & treated & 0.0000 & 1.0407 & 1.1344 \\
Abram Creek above Glade & treated & 0.0000 & 0.7118 & 0.8190 \\
Abram Creek above Johnnycake & treated & 0.0000 & 0.7805 & 0.9839 \\
Abram Creek above Laurel & treated & 0.0000 & 0.8125 & 1.0098 \\
Abram Creek at Mouth & treated & 1.5124 & 1.3922 & 1.2382 \\
Emory Creek Headwater Left Fork & AMD & 0.0000 & 0.0000 & 0.0000 \\
Emory Creek at Mouth & treated & 0.0000 & 0.8230 & 0.7620 \\
Emory Creek Headwater Right Fork & reference & 0.0000 & 0.0000 & 0.0785 \\
Glade Run at Mouth & treated & 0.0000 & 0.7155 & 0.7977 \\
Little Creek & treated & 0.0000 & 0.0000 & 0.0000 \\
Abram Creek Headwaters Right Fork & treated & 0.0000 & 0.0000 & 0.9422 \\
Johnnycake Run at Mouth & reference & 1.3260 & 1.3753 & 1.5096 \\
Upper Johnnycake Run & reference & 1.3253 & 1.2068 & 0.9919 \\
Laurel Run at Mouth & treated & 0.0000 & 0.0000 & 0.0000 \\
Abram Creek at Laytons & treated & 1.1283 & 1.0108 & 1.0817 \\
Unnamed Tributary 1 Emory Creek & AMD & 0.0000 & 0.0000 & 0.0000 \\
Unnamed Tributary 2 Emory Creek & reference & 0.5763 & 0.2089 & 0.6887 \\
Abram Creek at Vindex & treated & 0.0000 & 0.0000 & 0.6829
\end{tabular}




\section{Appendices}

Appendix 1. Fish species counts for sampling sites in Abram Creek for all sampling years (i.e. 2008, 2013, 2017). CACO = Catostomus commersoni (white sucker), MIDO = Micropterus dolomieu (smallmouth bass), RHAT $=$ Rhinichthys atratulus (blacknose dace), SAFO = Salvelinus fontinalis (brook trout), SEAT = Semotilus atromaculatus (creek chub), LECY = Lepomis cyanellus (green sunfish), COCA = Cottus caeruleomentum (Blue Ridge sculpin), ETFL = Etheostoma flabellare (fantail darter), OMNY = Oncorhynchus mykiss (rainbow trout), HYNI = Hypentelium nigricans (northern hogsucker), LEMA = Lepomis macrochirus (bluegill), AMRU = Ambloplites rupestris (rock bass), MIPU = Micropterus punctulatus (spotted bass), CAAN = Campostoma anomalum (central stoneroller).

\begin{tabular}{|c|c|c|c|c|c|c|c|c|c|c|c|c|c|c|c|c|}
\hline site & $\begin{array}{l}\text { stream } \\
\text { type }\end{array}$ & $\begin{array}{l}\text { sampling } \\
\text { year }\end{array}$ & CACO & MIDO & RHAT & SAFO & SEAT & LECY & COCA & ETFL & OMNY & HYNI & LEMA & AMRU & MIPU & CAAN \\
\hline $\begin{array}{l}\text { Abram Creek HW Right } \\
\text { Fork }\end{array}$ & treated & 2017 & 1 & 1 & 27 & 18 & 88 & 0 & 0 & 0 & 0 & 0 & 0 & 0 & 0 & 0 \\
\hline Little Creek & treated & 2017 & 0 & 0 & 0 & 5 & 0 & 0 & 0 & 0 & 0 & 0 & 0 & 0 & 0 & 0 \\
\hline Emory Creek HW Right Fork & reference & 2017 & 0 & 0 & 65 & 1 & 0 & 0 & 0 & 0 & 0 & 0 & 0 & 0 & 0 & 0 \\
\hline $\begin{array}{l}\text { Unnamed Tributary } 2 \text { Emory } \\
\text { Creek }\end{array}$ & reference & 2017 & 0 & 0 & 43 & 52 & 0 & 0 & 0 & 0 & 0 & 0 & 0 & 0 & 0 & 0 \\
\hline Laurel Run at Mouth & treated & 2017 & 0 & 0 & 0 & 1 & 0 & 0 & 0 & 0 & 0 & 0 & 0 & 0 & 0 & 0 \\
\hline Glade Run at Mouth & treated & 2017 & 3 & 0 & 127 & 21 & 16 & 1 & 0 & 0 & 0 & 0 & 0 & 0 & 0 & 0 \\
\hline Abram Creek at Vindex & treated & 2017 & 0 & 0 & 3 & 0 & 4 & 0 & 0 & 0 & 0 & 0 & 0 & 0 & 0 & 0 \\
\hline Emory Creek at Mouth & treated & 2017 & 0 & 0 & 77 & 12 & 16 & 0 & 0 & 0 & 0 & 0 & 0 & 0 & 0 & 0 \\
\hline Upper Johnnycake Run & reference & 2017 & 4 & 0 & 141 & 9 & 4 & 0 & 179 & 8 & 0 & 0 & 0 & 0 & 0 & 0 \\
\hline Johnnycake Run at Mouth & reference & 2017 & 13 & 0 & 43 & 15 & 12 & 0 & 41 & 2 & 0 & 0 & 0 & 0 & 0 & 0 \\
\hline Abram Creek at Mouth & treated & 2017 & 0 & 14 & 10 & 0 & 12 & 0 & 0 & 0 & 2 & 0 & 0 & 0 & 0 & 0 \\
\hline Abram Creek at Laytons & treated & 2017 & 1 & 26 & 50 & 0 & 15 & 0 & 0 & 0 & 0 & 1 & 0 & 0 & 0 & 0 \\
\hline Abram Creek above Emory & treated & 2017 & 1 & 42 & 45 & 0 & 44 & 0 & 0 & 0 & 0 & 0 & 0 & 0 & 0 & 0 \\
\hline $\begin{array}{l}\text { Abram Creek above } \\
\text { Johnnycake }\end{array}$ & treated & 2017 & 5 & 0 & 108 & 1 & 41 & 0 & 2 & 10 & 0 & 0 & 0 & 0 & 0 & 0 \\
\hline Abram Creek above Glade & treated & 2017 & 0 & 0 & 102 & 1 & 88 & 2 & 0 & 0 & 0 & 0 & 2 & 0 & 0 & 0 \\
\hline
\end{tabular}




\begin{tabular}{|c|c|c|c|c|c|c|c|c|c|c|c|c|c|c|c|c|}
\hline Abram Creek above Laurel & treated & 2017 & 1 & 1 & 27 & 6 & 42 & 0 & 0 & 0 & 0 & 0 & 0 & 0 & 0 & 0 \\
\hline Emory Creek HW Left Fork & AMD & 2017 & 0 & 0 & 0 & 0 & 0 & 0 & 0 & 0 & 0 & 0 & 0 & 0 & 0 & 0 \\
\hline $\begin{array}{l}\text { Unnamed Tributary } 1 \text { Emory } \\
\text { Creek }\end{array}$ & AMD & 2017 & 0 & 0 & 0 & 0 & 0 & 0 & 0 & 0 & 0 & 0 & 0 & 0 & 0 & 0 \\
\hline Abram Creek HW Right Fork & treated & 2008 & 0 & 0 & 0 & 0 & 0 & 0 & 0 & 0 & 0 & 0 & 0 & 0 & 0 & 0 \\
\hline Little Creek & treated & 2008 & 0 & 0 & 0 & 0 & 0 & 0 & 0 & 0 & 0 & 0 & 0 & 0 & 0 & 0 \\
\hline Emory Creek HW Right Fork & reference & 2008 & 0 & 0 & 71 & 0 & 0 & 0 & 0 & 0 & 0 & 0 & 0 & 0 & 0 & 0 \\
\hline $\begin{array}{l}\text { Unnamed Tributary } 2 \text { Emory } \\
\text { Creek }\end{array}$ & reference & 2008 & 0 & 0 & 84 & 30 & 0 & 0 & 0 & 0 & 0 & 0 & 0 & 0 & 0 & 0 \\
\hline Laurel Run at Mouth & treated & 2008 & 0 & 0 & 0 & 0 & 0 & 0 & 0 & 0 & 0 & 0 & 0 & 0 & 0 & 0 \\
\hline Glade Run at Mouth & treated & 2008 & 0 & 0 & 0 & 0 & 0 & 0 & 0 & 0 & 0 & 0 & 0 & 0 & 0 & 0 \\
\hline Abram Creek at Vindex & treated & 2008 & 0 & 0 & 0 & 0 & 0 & 0 & 0 & 0 & 0 & 0 & 0 & 0 & 0 & 0 \\
\hline Emory Creek at Mouth & treated & 2008 & 0 & 0 & 0 & 0 & 0 & 0 & 0 & 0 & 0 & 0 & 0 & 0 & 0 & 0 \\
\hline Upper Johnnycake Run & reference & 2008 & 7 & 0 & 84 & 33 & 5 & 0 & 56 & 4 & 0 & 0 & 0 & 0 & 0 & 0 \\
\hline Johnnycake Run & reference & 2008 & 46 & 0 & 329 & 13 & 59 & 0 & 110 & 38 & 0 & 0 & 0 & 0 & 0 & 0 \\
\hline Abram Creek at Mouth & treated & 2008 & 0 & 3 & 3 & 1 & 5 & 0 & 0 & 0 & 0 & 0 & 0 & 3 & 0 & 0 \\
\hline Abram Creek at Laytons & treated & 2008 & 5 & 1 & 21 & 1 & 19 & 0 & 0 & 0 & 0 & 0 & 0 & 0 & 0 & 0 \\
\hline Abram Creek above Emory & treated & 2008 & 0 & 0 & 0 & 0 & 0 & 0 & 0 & 0 & 0 & 0 & 0 & 0 & 0 & 0 \\
\hline $\begin{array}{l}\text { Abram Creek above } \\
\text { Johnnycake }\end{array}$ & treated & 2008 & 0 & 0 & 0 & 0 & 0 & 0 & 0 & 0 & 0 & 0 & 0 & 0 & 0 & 0 \\
\hline Abram Creek above Glade & treated & 2008 & 0 & 0 & 0 & 0 & 4 & 0 & 0 & 0 & 0 & 0 & 0 & 0 & 0 & 0 \\
\hline Abram Creek above Laurel & treated & 2008 & 0 & 0 & 0 & 0 & 0 & 0 & 0 & 0 & 0 & 0 & 0 & 0 & 0 & 0 \\
\hline Emory Creek HW Left Fork & AMD & 2008 & 0 & 0 & 0 & 0 & 0 & 0 & 0 & 0 & 0 & 0 & 0 & 0 & 0 & 0 \\
\hline $\begin{array}{l}\text { Unnamed Tributary } 1 \text { Emory } \\
\text { Creek }\end{array}$ & AMD & 2008 & 0 & 0 & 0 & 0 & 0 & 0 & 0 & 0 & 0 & 0 & 0 & 0 & 0 & 0 \\
\hline
\end{tabular}




\begin{tabular}{|c|c|c|c|c|c|c|c|c|c|c|c|c|c|c|c|}
\hline Abram Creek HW Right Fork & treated & 2013 & 0 & 0 & 0 & 0 & 91 & 0 & 0 & 0 & 0 & 0 & 0 & 0 & 0 \\
\hline Little Creek & treated & 2013 & 0 & 0 & 0 & 0 & 46 & 0 & 0 & 0 & 0 & 0 & 0 & 0 & 0 \\
\hline Emory Creek HW Right Fork & reference & 2013 & 0 & 0 & 58 & 0 & 0 & 0 & 0 & 0 & 0 & 0 & 0 & 0 & 0 \\
\hline $\begin{array}{l}\text { Unnamed Tributary } 2 \text { Emory } \\
\text { Creek }\end{array}$ & reference & 2013 & 0 & 0 & 53 & 3 & 0 & 0 & 0 & 0 & 0 & 0 & 0 & 0 & 0 \\
\hline Laurel Run at Mouth & treated & 2013 & 0 & 0 & 0 & 0 & 0 & 0 & 0 & 0 & 0 & 0 & 0 & 0 & 0 \\
\hline Glade Run at Mouth & treated & 2013 & 0 & 0 & 120 & 11 & 30 & 0 & 0 & 0 & 0 & 0 & 0 & 0 & 0 \\
\hline Abram Creek at Vindex & treated & 2013 & 0 & 0 & 0 & 0 & 69 & 0 & 0 & 0 & 0 & 0 & 0 & 0 & 0 \\
\hline Emory Creek at Mouth & treated & 2013 & 0 & 0 & 94 & 9 & 46 & 0 & 0 & 0 & 0 & 0 & 0 & 0 & 0 \\
\hline Upper Johnnycake Run & reference & 2013 & 3 & 0 & 86 & 9 & 8 & 0 & 64 & 7 & 0 & 0 & 0 & 0 & 0 \\
\hline Johnnycake Run at Mouth & reference & 2013 & 88 & 0 & 351 & 11 & 74 & 0 & 72 & 57 & 0 & 0 & 0 & 0 & 0 \\
\hline Abram Creek at Mouth & treated & 2013 & 1 & 13 & 29 & 1 & 28 & 0 & 0 & 4 & 0 & 0 & 0 & 0 & 0 \\
\hline Abram Creek at Laytons & treated & 2013 & 2 & 7 & 42 & 0 & 27 & 0 & 0 & 0 & 0 & 0 & 0 & 0 & 0 \\
\hline Abram Creek above Emory & treated & 2013 & 0 & 26 & 15 & 0 & 36 & 0 & 0 & 0 & 0 & 0 & 0 & 0 & 0 \\
\hline $\begin{array}{l}\text { Abram Creek above } \\
\text { Johnnycake }\end{array}$ & treated & 2013 & 2 & 0 & 133 & 0 & 91 & 0 & 0 & 3 & 0 & 0 & 0 & 0 & 0 \\
\hline Abram Creek above Glade & treated & 2013 & 1 & 0 & 89 & 0 & 116 & 0 & 0 & 0 & 0 & 0 & 0 & 0 & 0 \\
\hline Abram Creek above Laurel & treated & 2013 & 1 & 0 & 71 & 0 & 87 & 2 & 0 & 0 & 0 & 0 & 0 & 0 & 1 \\
\hline Emory Creek HW Left Fork & AMD & 2013 & 0 & 0 & 0 & 0 & 0 & 0 & 0 & 0 & 0 & 0 & 0 & 0 & 0 \\
\hline $\begin{array}{l}\text { Unnamed Tributary } 1 \text { Emory } \\
\text { Creek }\end{array}$ & AMD & 2013 & 0 & 0 & 0 & 0 & 0 & 0 & 0 & 0 & 0 & 0 & 0 & 0 & 0 \\
\hline
\end{tabular}


Appendix 2. Fish species counts for sampling sites in Three Forks Creek for both sampling years (i.e. 2008, 2017). AMNA = Ameiurus natalis (yellow bullhead), AMNE = Ameiurus nebulosus (brown bullhead), AMRU = Ambloplites rupestris (rock bass), CAAN = Campostoma anomalum (central stoneroller), $\mathrm{CACO}=$ Catostomus commersoni (white sucker), $\mathrm{COBA}=$ Cottus bairdii (mottled sculpin), ETBL = Etheostoma blennioides (greenside darter), ETFL = Etheostoma flabellare (fantail darter), HYNI = Hypentelium nigricans (northern hogsucker), LECY = Lepomis cyanellus (green sunfish), LEGI = Lepomis gibbosus (pumpkinseed sunfish), LEMA = Lepomis macrochirus (bluegill), MIDO = Micropterus dolomieu (smallmouth bass), MISA = Micropterus salmoides (largemouth bass), NOMI = Nocomis micropogon (river chub), NORU = Notropis rubellus (rosyface shiner), PECA = Percina caprodes $($ logperch), PINO = Pimephales notatus (bluntnose minnow), RHOB = Rhinichthys obtusus $($ blacknose dace), SATR = Salmo trutta (brown trout), SAVI = Sander vitreus (walleye), SEAT = Semotilus atromaculatus (creek chub).

\begin{tabular}{|c|c|c|c|c|c|c|c|c|c|c|c|c|c|c|c|c|c|c|c|c|c|c|c|}
\hline site & year & $\sum_{<}^{\nwarrow}$ & $\sum_{<}^{u}$ & 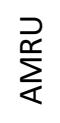 & $\frac{2}{4}$ & ৩ & 离 & $\overrightarrow{\underline{m}}$ & 岕 & $\sum_{\grave{I}}$ & 己 & ভ্ & $\sum_{\Perp}^{\nwarrow}$ & 을 & $\frac{\overleftarrow{N}}{\Sigma}$ & $\begin{array}{l}\bar{\Sigma} \\
\bar{z}\end{array}$ & $\begin{array}{l}\text { 뭉 } \\
\text { 을 }\end{array}$ & 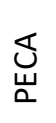 & $\frac{0}{a}$ & $\begin{array}{l}\stackrel{\infty}{0} \\
\stackrel{0}{\simeq}\end{array}$ & 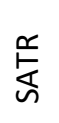 & $\underset{n}{i}$ & 离 \\
\hline $\begin{array}{c}\text { Three Forks } \\
\text { at Mouth }\end{array}$ & 2017 & 4 & 0 & 20 & 0 & 0 & 0 & 36 & 0 & 3 & 13 & 0 & 1 & 14 & 1 & 4 & 0 & 2 & 0 & 0 & 0 & 0 & 0 \\
\hline $\begin{array}{c}\text { Raccoon at } \\
\text { Mouth }\end{array}$ & 2017 & 0 & 0 & 3 & 0 & 0 & 0 & 1 & 0 & 0 & 15 & 0 & 3 & 1 & 0 & 1 & 0 & 0 & 0 & 0 & 0 & 1 & 53 \\
\hline $\begin{array}{l}\text { Upper } \\
\text { Raccoon } \\
\text { Creek }\end{array}$ & 2017 & 0 & 0 & 0 & 0 & 0 & 0 & 0 & 0 & 0 & 0 & 0 & 0 & 0 & 0 & 0 & 0 & 0 & 0 & 0 & 0 & 0 & 0 \\
\hline Raccoon HW & 2017 & 0 & 0 & 0 & 0 & 0 & 0 & 0 & 0 & 0 & 0 & 0 & 0 & 0 & 0 & 0 & 0 & 0 & 0 & 0 & 0 & 0 & 0 \\
\hline $\begin{array}{l}\text { Upper Birds } \\
\text { Creek }\end{array}$ & 2017 & 0 & 0 & 0 & 0 & 0 & 0 & 0 & 0 & 0 & 0 & 0 & 0 & 0 & 0 & 0 & 0 & 0 & 0 & 0 & 0 & 0 & 0 \\
\hline $\begin{array}{l}\text { Birds Creek } \\
\text { HW }\end{array}$ & 2017 & 0 & 0 & 0 & 0 & 0 & 0 & 0 & 0 & 0 & 0 & 0 & 0 & 0 & 0 & 0 & 0 & 0 & 0 & 0 & 0 & 0 & 0 \\
\hline Brains Creek & 2017 & 0 & 0 & 0 & 0 & 0 & 0 & 0 & 0 & 0 & 0 & 0 & 0 & 0 & 0 & 0 & 0 & 0 & 0 & 3 & 1 & 0 & 11 \\
\hline Boyd Run & 2017 & 0 & 0 & 0 & 0 & 12 & 0 & 0 & 0 & 0 & 0 & 0 & 5 & 0 & 4 & 0 & 0 & 0 & 0 & 11 & 2 & 0 & 48 \\
\hline $\begin{array}{r}\text { Squires } \\
\text { Creek }\end{array}$ & 2017 & 0 & 0 & 0 & 0 & 0 & 0 & 0 & 0 & 0 & 0 & 0 & 0 & 0 & 0 & 0 & 0 & 0 & 0 & 0 & 0 & 0 & 0 \\
\hline Birds Creek & 2017 & 0 & 0 & 0 & 0 & 0 & 0 & 0 & 0 & 0 & 0 & 0 & 0 & 0 & 0 & 0 & 0 & 0 & 0 & 0 & 0 & 0 & 31 \\
\hline Fields Creek & 2017 & 0 & 1 & 0 & 0 & 4 & 21 & 0 & 0 & 0 & 0 & 0 & 0 & 0 & 3 & 0 & 0 & 0 & 0 & 14 & 0 & 0 & 137 \\
\hline Stacks Creek & 2017 & 0 & 2 & 0 & 0 & 0 & 0 & 0 & 0 & 0 & 0 & 0 & 2 & 0 & 0 & 0 & 0 & 0 & 0 & 68 & 0 & 0 & 49 \\
\hline
\end{tabular}




\begin{tabular}{|c|c|c|c|c|c|c|c|c|c|c|c|c|c|c|c|c|c|c|c|c|c|c|c|}
\hline $\begin{array}{c}\text { Three Forks } \\
\text { above } \\
\text { Laurel }\end{array}$ & 2017 & 0 & 0 & 0 & 0 & 1 & 0 & 0 & 0 & 1 & 0 & 0 & 0 & 2 & 0 & 0 & 0 & 0 & 0 & 0 & 0 & 0 & 151 \\
\hline Laurel Creek & 2017 & 0 & 0 & 0 & 0 & 11 & 222 & 0 & 0 & 6 & 0 & 0 & 1 & 4 & 0 & 0 & 0 & 0 & 0 & 128 & 1 & 0 & 345 \\
\hline $\begin{array}{l}\text { Three Forks } \\
\text { at TF } \\
\text { Bridge }\end{array}$ & 2017 & 0 & 0 & 0 & 0 & 1 & 0 & 0 & 0 & 0 & 0 & 0 & 0 & 0 & 0 & 0 & 0 & 0 & 0 & 0 & 0 & 0 & 359 \\
\hline $\begin{array}{l}\text { Three Forks } \\
\text { above } \\
\text { Raccoon }\end{array}$ & 2017 & 0 & 0 & 8 & 0 & 1 & 0 & 4 & 0 & 6 & 9 & 0 & 1 & 3 & 1 & 2 & 0 & 1 & 0 & 0 & 0 & 0 & 17 \\
\hline Cooks Run & 2017 & 0 & 0 & 0 & 0 & 0 & 0 & 0 & 0 & 0 & 0 & 0 & 0 & 0 & 0 & 0 & 0 & 0 & 0 & 248 & 0 & 0 & 321 \\
\hline $\begin{array}{l}\text { UNT Laurel } \\
\text { Creek }\end{array}$ & 2017 & 0 & 0 & 0 & 0 & 0 & 107 & 0 & 0 & 0 & 0 & 0 & 0 & 0 & 0 & 0 & 0 & 0 & 0 & 110 & 0 & 0 & 150 \\
\hline $\begin{array}{l}\text { Three Forks } \\
\text { at } \\
\text { Thornton }\end{array}$ & 2017 & 3 & 0 & 13 & 1 & 0 & 0 & 21 & 4 & 4 & 33 & 0 & 2 & 19 & 0 & 1 & 2 & 0 & 15 & 0 & 0 & 1 & 0 \\
\hline $\begin{array}{l}\text { Unnamed } \\
\text { Tributary } \\
\text { Birds } \\
\text { Creek at } \\
58\end{array}$ & 2017 & 0 & 0 & 0 & 0 & 0 & 0 & 0 & 0 & 0 & 0 & 0 & 0 & 0 & 0 & 0 & 0 & 0 & 0 & 0 & 0 & 0 & 0 \\
\hline $\begin{array}{c}\text { Three Forks } \\
\text { at Mouth }\end{array}$ & 2008 & 0 & 0 & 0 & 0 & 0 & 0 & 0 & 0 & 0 & 0 & 0 & 0 & 0 & 0 & 0 & 0 & 0 & 0 & 0 & 0 & 0 & 0 \\
\hline $\begin{array}{c}\text { Raccoon at } \\
\text { Mouth }\end{array}$ & 2008 & 0 & 0 & 0 & 0 & 0 & 0 & 0 & 0 & 0 & 0 & 0 & 0 & 0 & 0 & 0 & 0 & 0 & 0 & 0 & 0 & 0 & 0 \\
\hline $\begin{array}{l}\text { Upper } \\
\text { Raccoon } \\
\text { Creek }\end{array}$ & 2008 & 0 & 0 & 0 & 0 & 0 & 0 & 0 & 0 & 0 & 0 & 0 & 0 & 0 & 0 & 0 & 0 & 0 & 0 & 0 & 0 & 0 & 0 \\
\hline Raccoon HW & 2008 & 0 & 0 & 0 & 0 & 0 & 0 & 0 & 0 & 0 & 0 & 0 & 0 & 0 & 0 & 0 & 0 & 0 & 0 & 0 & 0 & 0 & 0 \\
\hline $\begin{array}{l}\text { Upper Birds } \\
\text { Creek }\end{array}$ & 2008 & 0 & 0 & 0 & 0 & 0 & 0 & 0 & 0 & 0 & 0 & 0 & 0 & 0 & 0 & 0 & 0 & 0 & 0 & 0 & 0 & 0 & 0 \\
\hline $\begin{array}{l}\text { Birds Creek } \\
\text { HW }\end{array}$ & 2008 & 0 & 0 & 0 & 0 & 0 & 0 & 0 & 0 & 0 & 0 & 0 & 0 & 0 & 0 & 0 & 0 & 0 & 0 & 0 & 0 & 0 & 0 \\
\hline Brains Creek & 2008 & 0 & 0 & 0 & 0 & 0 & 2 & 0 & 0 & 0 & 0 & 0 & 0 & 0 & 0 & 0 & 0 & 0 & 0 & 0 & 0 & 0 & 4 \\
\hline Boyd Run & 2008 & 0 & 0 & 0 & 0 & 41 & 0 & 0 & 0 & 0 & 0 & 0 & 1 & 0 & 2 & 0 & 0 & 0 & 0 & 51 & 6 & 0 & 103 \\
\hline
\end{tabular}




\begin{tabular}{|c|c|c|c|c|c|c|c|c|c|c|c|c|c|c|c|c|c|c|c|c|c|c|c|}
\hline $\begin{array}{l}\text { Squires } \\
\text { Creek }\end{array}$ & 2008 & 0 & 0 & 0 & 0 & 0 & 0 & 0 & 0 & 0 & 0 & 0 & 0 & 0 & 0 & 0 & 0 & 0 & 0 & 0 & 0 & 0 & 0 \\
\hline Birds Creek & 2008 & 0 & 0 & 0 & 0 & 0 & 0 & 0 & 0 & 0 & 0 & 0 & 0 & 0 & 0 & 0 & 0 & 0 & 0 & 0 & 0 & 0 & 0 \\
\hline Fields Creek & 2008 & 0 & 0 & 0 & 0 & 31 & 0 & 0 & 0 & 0 & 0 & 0 & 1 & 0 & 1 & 0 & 0 & 0 & 0 & 67 & 0 & 0 & 377 \\
\hline Stacks Creek & 2008 & 0 & 0 & 0 & 0 & 0 & 0 & 0 & 0 & 0 & 0 & 2 & 0 & 0 & 0 & 0 & 0 & 0 & 0 & 154 & 0 & 0 & 132 \\
\hline $\begin{array}{c}\text { Three Forks } \\
\text { above } \\
\text { Laurel }\end{array}$ & 2008 & 0 & 0 & 0 & 0 & 0 & 0 & 0 & 0 & 0 & 0 & 0 & 0 & 0 & 0 & 0 & 0 & 0 & 0 & 0 & 0 & 0 & 0 \\
\hline Laurel Creek & 2008 & 0 & 0 & 0 & 0 & 4 & 288 & 0 & 0 & 0 & 1 & 0 & 2 & 0 & 1 & 0 & 0 & 0 & 0 & 87 & 2 & 0 & 142 \\
\hline $\begin{array}{l}\text { Three Forks } \\
\text { at Three } \\
\text { Forks } \\
\text { Bridge }\end{array}$ & 2008 & 0 & 0 & 0 & 0 & 0 & 0 & 0 & 0 & 0 & 0 & 0 & 0 & 0 & 0 & 0 & 0 & 0 & 0 & 0 & 0 & 0 & 0 \\
\hline $\begin{array}{c}\text { Three Forks } \\
\text { above } \\
\text { Raccoon }\end{array}$ & 2008 & 0 & 0 & 0 & 0 & 0 & 0 & 0 & 0 & 0 & 0 & 0 & 0 & 0 & 0 & 0 & 0 & 0 & 0 & 0 & 0 & 0 & 0 \\
\hline Cooks Run & 2008 & 0 & 0 & 0 & 0 & 0 & 0 & 0 & 0 & 0 & 0 & 0 & 0 & 0 & 0 & 0 & 0 & 0 & 0 & 85 & 0 & 0 & 97 \\
\hline $\begin{array}{l}\text { UNT Laurel } \\
\text { Creek }\end{array}$ & 2008 & 0 & 0 & 0 & 0 & 0 & 98 & 0 & 0 & 0 & 2 & 0 & 0 & 0 & 0 & 0 & 0 & 0 & 0 & 30 & 0 & 0 & 237 \\
\hline $\begin{array}{l}\text { Three Forks } \\
\text { at } \\
\text { Thornton }\end{array}$ & 2008 & 0 & 0 & 0 & 0 & 0 & 0 & 0 & 0 & 0 & 0 & 0 & 0 & 0 & 0 & 0 & 0 & 0 & 0 & 0 & 0 & 0 & 0 \\
\hline $\begin{array}{l}\text { Unnamed } \\
\text { Tributary } \\
\text { Birds } \\
\text { Creek at } \\
58\end{array}$ & 2008 & 0 & 0 & 0 & 0 & 0 & 0 & 0 & 0 & 0 & 0 & 0 & 0 & 0 & 0 & 0 & 0 & 0 & 0 & 0 & 0 & 0 & 0 \\
\hline
\end{tabular}


Appendix 3. Benthic macroinvertebrate data for Abram Creek by sample location in 2008. With the exception of Chironomidae, macroinvertebrates were identified to genus if possible. UNK=unknown.

\begin{tabular}{|c|c|c|c|c|c|c|c|c|c|c|c|c|c|c|}
\hline & 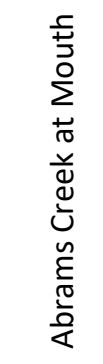 & 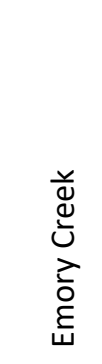 & 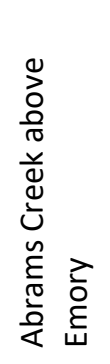 & 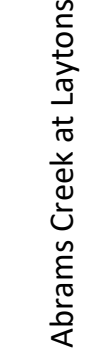 & 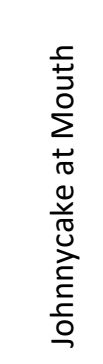 & 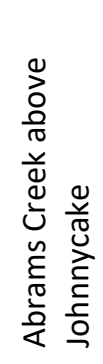 & $\begin{array}{l}\frac{c}{J} \\
\frac{d}{d} \\
\frac{d}{0} \\
\frac{\pi}{v}\end{array}$ & 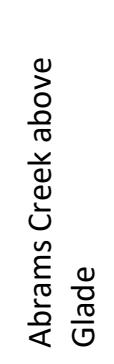 & 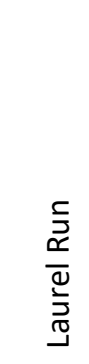 & 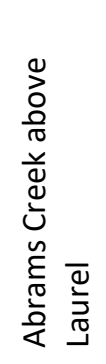 & 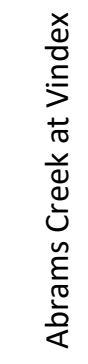 & 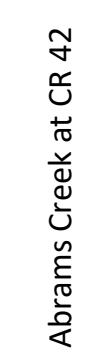 & 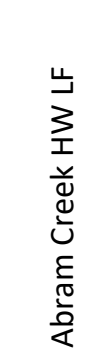 & 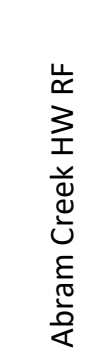 \\
\hline Year & 2008 & 2008 & 2008 & 2008 & 2008 & 2008 & 2008 & 2008 & 2008 & 2008 & 2008 & 2008 & 2008 & 2008 \\
\hline Oligochaeta & 4 & 4 & 5 & 1 & 22 & 1 & 12 & 2 & 0 & 0 & 2 & 2 & 9 & 4 \\
\hline Planorbidae & 0 & 0 & 0 & 0 & 0 & 0 & 0 & 0 & 0 & 0 & 0 & 1 & 0 & 0 \\
\hline Lymnaeidae & 0 & 0 & 0 & 0 & 0 & 0 & 0 & 0 & 0 & 0 & 0 & 1 & 0 & 0 \\
\hline Snails(UNK) & 0 & 0 & 0 & 0 & 0 & 0 & 0 & 0 & 0 & 0 & 0 & 1 & 0 & 0 \\
\hline Gammarus & 0 & 0 & 0 & 0 & 0 & 0 & 0 & 0 & 0 & 0 & 0 & 0 & 0 & 0 \\
\hline Caecidotea & 1 & 0 & 0 & 0 & 0 & 0 & 0 & 1 & 0 & 0 & 0 & 0 & 0 & 0 \\
\hline Baetidae(UNK) & 2 & 0 & 5 & 6 & 3 & 0 & 6 & 0 & 0 & 0 & 1 & 0 & 0 & 0 \\
\hline Accentrella & 2 & 0 & 3 & 3 & 5 & 0 & 5 & 0 & 0 & 0 & 0 & 0 & 0 & 0 \\
\hline Baetis & 0 & 0 & 2 & 0 & 0 & 0 & 17 & 0 & 0 & 0 & 0 & 0 & 0 & 0 \\
\hline Plauditus & 67 & 0 & 58 & 112 & 7 & 0 & 0 & 0 & 0 & 0 & 0 & 0 & 0 & 0 \\
\hline Heterocloeon & 0 & 0 & 0 & 0 & 0 & 0 & 0 & 0 & 0 & 0 & 0 & 0 & 0 & 0 \\
\hline Centroptilum & 0 & 0 & 0 & 0 & 0 & 0 & 0 & 0 & 0 & 0 & 0 & 0 & 0 & 0 \\
\hline Heptageniidae(UNK) & 0 & 0 & 1 & 0 & 2 & 0 & 0 & 0 & 0 & 0 & 0 & 0 & 0 & 0 \\
\hline Epeorus & 0 & 0 & 0 & 0 & 5 & 0 & 0 & 0 & 0 & 0 & 0 & 0 & 0 & 0 \\
\hline Heptagenia & 0 & 0 & 0 & 0 & 0 & 0 & 0 & 0 & 0 & 0 & 0 & 0 & 0 & 0 \\
\hline Stenonema/Maccaffertium & 0 & 0 & 0 & 0 & 3 & 0 & 1 & 0 & 0 & 0 & 0 & 0 & 0 & 0 \\
\hline Cinygmula & 0 & 0 & 0 & 0 & 0 & 0 & 1 & 0 & 0 & 0 & 0 & 0 & 0 & 0 \\
\hline Stenacron & 0 & 0 & 0 & 0 & 0 & 0 & 0 & 0 & 0 & 0 & 0 & 0 & 0 & 0 \\
\hline Isonychia & 0 & 0 & 0 & 0 & 0 & 0 & 0 & 0 & 0 & 0 & 0 & 0 & 0 & 0 \\
\hline Leptophelbiidae(UNK) & 0 & 0 & 0 & 0 & 0 & 0 & 0 & 0 & 0 & 0 & 0 & 0 & 0 & 0 \\
\hline Paraleptophlebia & 0 & 0 & 0 & 0 & 0 & 0 & 0 & 0 & 0 & 0 & 0 & 0 & 0 & 0 \\
\hline
\end{tabular}




\begin{tabular}{|c|c|c|c|c|c|c|c|c|c|c|c|c|c|}
\hline Ephemerellidae(UNK) & 0 & 0 & 0 & 0 & 0 & 0 & 0 & 0 & 0 & 1 & 0 & 0 & 0 \\
\hline Ephemerella & 0 & 0 & 0 & 0 & 8 & 0 & 0 & 1 & 0 & 0 & 0 & 0 & 0 \\
\hline Drunella & 0 & 0 & 0 & 0 & 0 & 0 & 0 & 0 & 0 & 0 & 0 & 0 & 0 \\
\hline Tricorythodes & 0 & 0 & 0 & 0 & 0 & 0 & 0 & 0 & 0 & 0 & 0 & 0 & 0 \\
\hline Ephemera & 0 & 0 & 0 & 0 & 0 & 0 & 0 & 0 & 0 & 0 & 0 & 0 & 0 \\
\hline Ameletus & 0 & 0 & 0 & 0 & 0 & 0 & 0 & 0 & 0 & 0 & 0 & 0 & 0 \\
\hline Unknown Mayfly & 1 & 1 & 2 & 2 & 1 & 0 & 2 & 0 & 0 & 0 & 0 & 0 & 0 \\
\hline Hydropsychidae(UNK) & 0 & 0 & 0 & 0 & 0 & 0 & 0 & 0 & 0 & 0 & 0 & 0 & 0 \\
\hline Hydropsyche & 0 & 0 & 2 & 5 & 0 & 0 & 0 & 0 & 0 & 0 & 0 & 0 & 0 \\
\hline Diplectrona & 0 & 6 & 0 & 0 & 3 & 0 & 3 & 2 & 0 & 2 & 5 & 0 & 0 \\
\hline Ceratopsyche & 0 & 1 & 0 & 0 & 0 & 0 & 3 & 0 & 0 & 0 & 0 & 0 & 0 \\
\hline Cheumatopsyche & 0 & 0 & 0 & 0 & 3 & 0 & 2 & 0 & 0 & 0 & 0 & 0 & 0 \\
\hline Wormaldia & 0 & 0 & 0 & 0 & 0 & 0 & 0 & 0 & 0 & 0 & 0 & 0 & 0 \\
\hline Chimarra & 1 & 0 & 0 & 1 & 0 & 0 & 0 & 0 & 0 & 0 & 0 & 0 & 0 \\
\hline Dolophilodes & 0 & 0 & 0 & 0 & 10 & 0 & 5 & 0 & 0 & 0 & 0 & 0 & 0 \\
\hline Rhyacophilla & 0 & 0 & 0 & 0 & 1 & 0 & 0 & 0 & 0 & 1 & 0 & 0 & 0 \\
\hline UNK (Polycentropodidae) & 0 & 0 & 0 & 1 & 0 & 0 & 0 & 0 & 0 & 0 & 0 & 0 & 0 \\
\hline Polycentropus & 1 & 0 & 1 & 0 & 0 & 0 & 0 & 1 & 0 & 0 & 0 & 0 & 1 \\
\hline Cyrnellus & 0 & 1 & 0 & 0 & 0 & 0 & 0 & 0 & 0 & 0 & 0 & 0 & 0 \\
\hline Lepidostoma & 0 & 0 & 0 & 0 & 0 & 0 & 0 & 0 & 0 & 0 & 0 & 0 & 0 \\
\hline Pycnopsyche & 0 & 0 & 0 & 0 & 0 & 0 & 0 & 1 & 0 & 0 & 0 & 0 & 0 \\
\hline Hydatophylax & 0 & 0 & 0 & 0 & 0 & 0 & 0 & 0 & 0 & 0 & 0 & 0 & 0 \\
\hline Leptoceridae(UNK) & 2 & 0 & 0 & 0 & 0 & 0 & 0 & 0 & 0 & 0 & 0 & 0 & 0 \\
\hline Hydroptilidae (UNK) & 0 & 0 & 0 & 0 & 0 & 0 & 0 & 0 & 0 & 0 & 0 & 0 & 0 \\
\hline Hydroptila & 0 & 0 & 0 & 0 & 4 & 0 & 1 & 0 & 0 & 0 & 0 & 0 & 0 \\
\hline Orthotrichia & 0 & 0 & 0 & 0 & 0 & 0 & 0 & 0 & 0 & 0 & 0 & 0 & 0 \\
\hline Ochrotrichia & 0 & 0 & 0 & 0 & 0 & 0 & 0 & 0 & 0 & 0 & 0 & 0 & 0 \\
\hline Agapetus & 0 & 0 & 0 & 0 & 0 & 0 & 0 & 0 & 0 & 0 & 0 & 0 & 0 \\
\hline Glossosoma & 0 & 0 & 0 & 0 & 0 & 0 & 0 & 0 & 0 & 0 & 0 & 0 & 0 \\
\hline Neophylax & 0 & 0 & 0 & 0 & 0 & 0 & 0 & 0 & 0 & 0 & 0 & 0 & 0 \\
\hline Phryganeidae(UNK) & 0 & 0 & 0 & 0 & 0 & 0 & 0 & 0 & 0 & 0 & 0 & 0 & 0 \\
\hline Unkown Caddisfly & 1 & 0 & 0 & 0 & 0 & 0 & 0 & 0 & 0 & 2 & 0 & 0 & 0 \\
\hline Chloroperlidae(UNK) & 0 & 0 & 0 & 0 & 1 & 0 & 0 & 0 & 0 & 0 & 0 & 0 & 0 \\
\hline
\end{tabular}




\begin{tabular}{|c|c|c|c|c|c|c|c|c|c|c|c|c|c|}
\hline Haploperla & 0 & 0 & 2 & 0 & 3 & 0 & 4 & 0 & 0 & 0 & 0 & 0 & 0 \\
\hline Sweltsa & 0 & 0 & 0 & 0 & 0 & 0 & 0 & 0 & 0 & 0 & 0 & 0 & 0 \\
\hline Alloperla & 3 & 1 & 1 & 2 & 0 & 2 & 3 & 1 & 0 & 0 & 0 & 0 & 0 \\
\hline Allocapnia & 0 & 0 & 0 & 0 & 0 & 0 & 0 & 0 & 0 & 0 & 0 & 0 & 0 \\
\hline Leuctra & 20 & 1 & 35 & 17 & 23 & 1 & 17 & 0 & 0 & 0 & 0 & 0 & 0 \\
\hline Acroneuria & 0 & 0 & 2 & 1 & 1 & 0 & 1 & 0 & 0 & 0 & 0 & 0 & 0 \\
\hline Agnetina & 0 & 0 & 0 & 0 & 1 & 0 & 0 & 0 & 0 & 0 & 0 & 0 & 0 \\
\hline Beloneuria & 0 & 0 & 0 & 0 & 0 & 0 & 0 & 0 & 0 & 0 & 0 & 0 & 0 \\
\hline Hansonoperla & 0 & 0 & 0 & 0 & 0 & 0 & 0 & 0 & 0 & 0 & 0 & 0 & 0 \\
\hline Paragnetina & 0 & 0 & 0 & 1 & 0 & 0 & 0 & 0 & 0 & 0 & 0 & 0 & 0 \\
\hline Pteronarcys & 0 & 0 & 0 & 0 & 1 & 0 & 0 & 0 & 0 & 0 & 0 & 0 & 0 \\
\hline Perlodidae(UNK) & 0 & 0 & 0 & 0 & 0 & 0 & 0 & 0 & 0 & 0 & 0 & 0 & 0 \\
\hline Isoperla & 0 & 0 & 0 & 0 & 1 & 0 & 2 & 0 & 0 & 0 & 0 & 0 & 0 \\
\hline Yugus & 0 & 0 & 0 & 0 & 0 & 0 & 0 & 0 & 0 & 0 & 0 & 0 & 0 \\
\hline Tallaperla & 0 & 0 & 0 & 0 & 0 & 0 & 0 & 0 & 0 & 0 & 0 & 0 & 0 \\
\hline Peltoperla & 0 & 0 & 0 & 0 & 4 & 0 & 0 & 0 & 0 & 0 & 0 & 0 & 0 \\
\hline Amphinemuera & 1 & 1 & 1 & 0 & 3 & 0 & 35 & 0 & 0 & 1 & 0 & 0 & 0 \\
\hline Paranemoura & 0 & 0 & 0 & 0 & 0 & 0 & 0 & 0 & 0 & 0 & 0 & 0 & 0 \\
\hline Taeniopteryx & 0 & 0 & 1 & 0 & 10 & 0 & 1 & 0 & 0 & 0 & 0 & 0 & 0 \\
\hline Taeniopterygidae(UNK) & 0 & 0 & 0 & 0 & 0 & 0 & 0 & 0 & 0 & 0 & 0 & 0 & 0 \\
\hline Unknown Stonefly & 4 & 3 & 4 & 2 & 8 & 0 & 14 & 0 & 0 & 0 & 0 & 0 & 0 \\
\hline Gomphidae(UNK) & 0 & 0 & 0 & 0 & 0 & 0 & 0 & 0 & 0 & 0 & 0 & 0 & 0 \\
\hline Lanthus & 0 & 0 & 0 & 0 & 0 & 0 & 0 & 0 & 0 & 0 & 0 & 0 & 0 \\
\hline Stylogomphus & 0 & 0 & 0 & 0 & 0 & 0 & 0 & 0 & 0 & 0 & 0 & 0 & 0 \\
\hline Aeshnidae (UNK) & 0 & 0 & 0 & 0 & 0 & 0 & 0 & 0 & 0 & 0 & 0 & 0 & 0 \\
\hline Boyeria & 0 & 0 & 0 & 0 & 0 & 0 & 0 & 0 & 0 & 0 & 0 & 0 & 0 \\
\hline Calopteryx & 0 & 0 & 0 & 0 & 0 & 0 & 0 & 0 & 0 & 0 & 0 & 0 & 0 \\
\hline Elmidae(UNK) & 0 & 0 & 0 & 0 & 0 & 0 & 0 & 0 & 0 & 0 & 0 & 0 & 0 \\
\hline Optioservus & 4 & 0 & 2 & 0 & 0 & 0 & 0 & 2 & 0 & 0 & 0 & 0 & 0 \\
\hline Promoresia & 0 & 0 & 1 & 0 & 0 & 0 & 0 & 0 & 0 & 0 & 0 & 0 & 0 \\
\hline Oulimnius & 0 & 0 & 0 & 0 & 4 & 0 & 1 & 0 & 0 & 0 & 0 & 0 & 0 \\
\hline Ancyronyx & 0 & 0 & 0 & 0 & 0 & 0 & 0 & 0 & 0 & 0 & 0 & 0 & 0 \\
\hline Stenelmis & 0 & 0 & 0 & 0 & 0 & 0 & 2 & 0 & 0 & 0 & 0 & 0 & 0 \\
\hline
\end{tabular}




\begin{tabular}{|c|c|c|c|c|c|c|c|c|c|c|c|c|c|}
\hline Dubiraphia & 0 & 0 & 0 & 0 & 0 & 0 & 0 & 0 & 0 & 0 & 0 & 0 & 0 \\
\hline Ectopria & 0 & 0 & 0 & 0 & 0 & 0 & 0 & 0 & 0 & 0 & 0 & 0 & 0 \\
\hline Psephenus & 0 & 0 & 0 & 0 & 1 & 0 & 0 & 0 & 0 & 0 & 0 & 0 & 0 \\
\hline Anchytarsus & 0 & 0 & 1 & 0 & 0 & 2 & 0 & 0 & 0 & 0 & 0 & 0 & 0 \\
\hline Curculionidae(UNK) & 0 & 1 & 0 & 0 & 0 & 0 & 0 & 0 & 0 & 0 & 0 & 0 & 0 \\
\hline Dytiscidae(UNK) & 0 & 0 & 0 & 1 & 0 & 0 & 0 & 0 & 0 & 0 & 0 & 0 & 0 \\
\hline Peltodytes & 0 & 0 & 0 & 0 & 0 & 0 & 0 & 0 & 0 & 0 & 0 & 0 & 0 \\
\hline Unknown Beetle & 0 & 0 & 0 & 0 & 0 & 0 & 0 & 1 & 0 & 0 & 0 & 0 & 0 \\
\hline Nigronia & 0 & 0 & 0 & 0 & 0 & 0 & 0 & 0 & 0 & 1 & 0 & 0 & 0 \\
\hline Sialis & 0 & 3 & 1 & 0 & 0 & 0 & 0 & 4 & 2 & 0 & 2 & 0 & 1 \\
\hline UNK & 0 & 0 & 0 & 0 & 0 & 0 & 0 & 0 & 0 & 0 & 0 & 0 & 0 \\
\hline Hemiptera (UNK) & 0 & 0 & 0 & 0 & 0 & 0 & 0 & 0 & 0 & 0 & 0 & 0 & 0 \\
\hline Mesovelia & 0 & 0 & 0 & 0 & 0 & 0 & 0 & 0 & 0 & 0 & 0 & 0 & 0 \\
\hline Chironomidae & 46 & 32 & 46 & 46 & 33 & 3 & 43 & 20 & 3 & 17 & 20 & 9 & 79 \\
\hline Tipulidae(UNK) & 0 & 0 & 0 & 0 & 0 & 0 & 2 & 0 & 0 & 1 & 0 & 0 & 0 \\
\hline Antocha & 0 & 0 & 0 & 1 & 0 & 0 & 0 & 0 & 0 & 0 & 0 & 0 & 0 \\
\hline Tipula & 0 & 0 & 1 & 1 & 0 & 0 & 0 & 0 & 0 & 0 & 1 & 0 & 0 \\
\hline Hexatoma & 0 & 0 & 2 & 4 & 0 & 0 & 2 & 0 & 1 & 0 & 0 & 0 & 0 \\
\hline Dicranota & 0 & 0 & 0 & 0 & 1 & 0 & 0 & 0 & 0 & 0 & 0 & 0 & 0 \\
\hline Molophilus & 0 & 2 & 1 & 0 & 0 & 0 & 0 & 0 & 0 & 1 & 0 & 0 & 0 \\
\hline Limnophila & 0 & 0 & 0 & 0 & 0 & 0 & 0 & 0 & 0 & 0 & 0 & 0 & 0 \\
\hline Pseudolimnophila & 0 & 0 & 0 & 0 & 0 & 0 & 2 & 0 & 0 & 0 & 0 & 0 & 0 \\
\hline Pedicia & 0 & 0 & 0 & 0 & 0 & 0 & 0 & 0 & 0 & 0 & 0 & 0 & 0 \\
\hline Limonia & 0 & 0 & 0 & 0 & 0 & 0 & 0 & 0 & 0 & 0 & 0 & 0 & 0 \\
\hline Chrysops & 0 & 0 & 0 & 0 & 0 & 0 & 0 & 0 & 0 & 0 & 0 & 0 & 0 \\
\hline Simuliidae(UNK) & 0 & 0 & 0 & 0 & 1 & 0 & 0 & 0 & 0 & 0 & 0 & 0 & 0 \\
\hline Simulium & 0 & 0 & 0 & 0 & 32 & 0 & 5 & 1 & 0 & 0 & 0 & 0 & 0 \\
\hline Prosimulium & 0 & 0 & 0 & 0 & 2 & 0 & 0 & 0 & 0 & 0 & 0 & 0 & 0 \\
\hline Empididae(UNK) & 0 & 0 & 0 & 0 & 0 & 0 & 0 & 0 & 0 & 0 & 0 & 1 & 0 \\
\hline Chelifera & 1 & 0 & 1 & 0 & 2 & 0 & 1 & 0 & 0 & 0 & 0 & 0 & 1 \\
\hline Clinocera & 0 & 0 & 0 & 0 & 0 & 0 & 4 & 0 & 0 & 0 & 0 & 0 & 0 \\
\hline Hemerodromia & 2 & 0 & 4 & 1 & 0 & 0 & 1 & 0 & 0 & 0 & 0 & 0 & 0 \\
\hline Ceratopogonidae(UNK) & 0 & 2 & 0 & 0 & 0 & 0 & 1 & 0 & 0 & 1 & 0 & 0 & 0 \\
\hline
\end{tabular}


Bezzia

Dasyhelea

Culicoides

Ceratopogon

Blepharicera

Psychodidae(UNK)

Unknown Diptera

Hydracarina

Collembola (UNK)

Bourletiella

Isotomorus

Isotomidae(UNK)

\begin{tabular}{|c|c|c|c|c|c|c|c|c|c|c|c|c|}
\hline 1 & 0 & 2 & 1 & 0 & 0 & 1 & 1 & 1 & 0 & 3 & 0 & 2 \\
\hline 1 & 4 & 7 & 0 & 0 & 0 & 1 & 0 & 0 & 0 & 0 & 0 & 0 \\
\hline 1 & 0 & 2 & 0 & 0 & 0 & 0 & 0 & 0 & 0 & 0 & 0 & 0 \\
\hline 0 & 0 & 0 & 0 & 0 & 0 & 0 & 0 & 0 & 0 & 0 & 0 & 0 \\
\hline 0 & 0 & 0 & 0 & 0 & 0 & 0 & 0 & 0 & 0 & 0 & 0 & 0 \\
\hline 0 & 0 & 0 & 0 & 0 & 0 & 0 & 0 & 0 & 0 & 0 & 0 & 0 \\
\hline 0 & 0 & 0 & 0 & 0 & 0 & 0 & 0 & 0 & 0 & 0 & 0 & 0 \\
\hline 0 & 0 & 0 & 0 & 0 & 0 & 0 & 0 & 0 & 0 & 0 & 0 & 0 \\
\hline 0 & 0 & 0 & 0 & 0 & 0 & 0 & 0 & 0 & 0 & 0 & 1 & 0 \\
\hline 0 & 0 & 0 & 0 & 0 & 0 & 0 & 0 & 0 & 0 & 0 & 0 & 3 \\
\hline 0 & 0 & 0 & 0 & 0 & 0 & 0 & 0 & 0 & 0 & 0 & 0 & 0 \\
\hline 0 & 1 & 0 & 0 & 1 & 0 & 0 & 0 & 0 & 0 & 0 & 1 & 1 \\
\hline
\end{tabular}


Appendix 4. Benthic macroinvertebrate data for Abram Creek by sample location in 2013. With the exception of Chironomidae, macroinvertebrates were identified to genus if possible. UNK=unknown.

\begin{tabular}{|c|c|c|c|c|c|c|c|c|c|c|c|c|c|c|c|c|c|c|}
\hline Site & 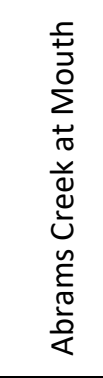 & 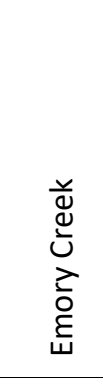 & 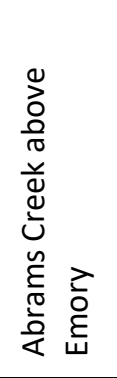 & 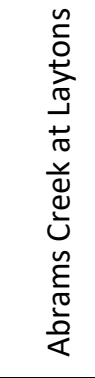 & 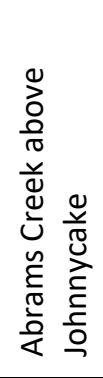 & $\begin{array}{l}\frac{5}{\partial} \\
\frac{1}{d} \\
\frac{0}{0} \\
\frac{\pi}{0}\end{array}$ & 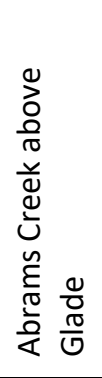 & 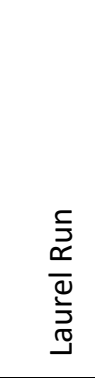 & 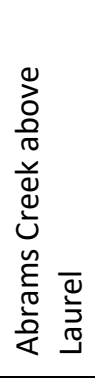 & 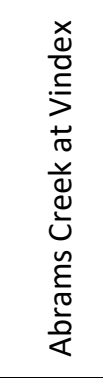 & 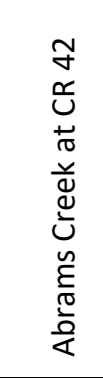 & 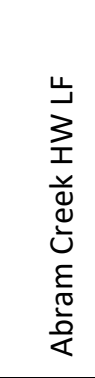 & 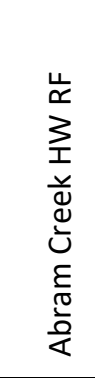 & 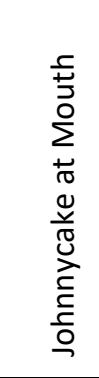 & 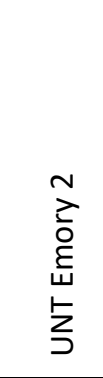 & 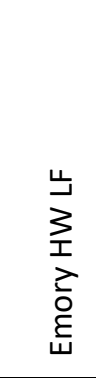 & 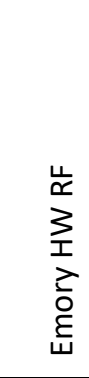 & 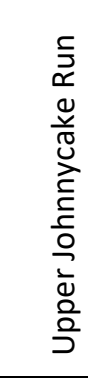 \\
\hline Year & 2013 & 2013 & 2013 & 2013 & 2013 & 2013 & 2013 & 2013 & 2013 & 2013 & 2013 & 2013 & 2013 & 2013 & 2013 & 2013 & 2013 & 2013 \\
\hline Oligochaeta & 5 & 4 & 4 & 3 & 6 & 4 & 1 & 4 & 6 & 0 & 0 & 2 & 3 & 0 & 0 & 2 & 2 & 0 \\
\hline Planorbidae & 0 & 0 & 0 & 0 & 0 & 1 & 0 & 0 & 0 & 0 & 0 & 0 & 0 & 0 & 0 & 0 & 0 & 0 \\
\hline Lymnaeidae & 0 & 0 & 0 & 0 & 0 & 0 & 0 & 0 & 0 & 0 & 0 & 0 & 0 & 0 & 0 & 0 & 0 & 0 \\
\hline Snails(UNK) & 1 & 1 & 0 & 0 & 0 & 0 & 0 & 0 & 0 & 0 & 0 & 0 & 0 & 1 & 0 & 0 & 0 & 0 \\
\hline Gammarus & 0 & 0 & 0 & 0 & 0 & 0 & 0 & 0 & 0 & 0 & 0 & 0 & 0 & 0 & 4 & 0 & 0 & 0 \\
\hline Caecidotea & 0 & 0 & 0 & 0 & 0 & 0 & 0 & 1 & 1 & 0 & 0 & 0 & 0 & 0 & 0 & 0 & 0 & 0 \\
\hline Baetidae(UNK) & 9 & 0 & 7 & 4 & 13 & 3 & 0 & 0 & 17 & 0 & 0 & 0 & 1 & 7 & 0 & 0 & 7 & 7 \\
\hline Accentrella & 5 & 0 & 7 & 6 & 19 & 0 & 10 & 0 & 13 & 8 & 0 & 0 & 2 & 11 & 0 & 0 & 0 & 9 \\
\hline Baetis & 2 & 0 & 4 & 3 & 2 & 2 & 0 & 0 & 5 & 0 & 0 & 0 & 1 & 3 & 12 & 0 & 27 & 8 \\
\hline Plauditus & 43 & 2 & 61 & 92 & 39 & 0 & 69 & 0 & 86 & 10 & 0 & 0 & 1 & 28 & 0 & 0 & 0 & 71 \\
\hline Heterocloeon & 0 & 0 & 0 & 0 & 0 & 0 & 0 & 0 & 0 & 0 & 0 & 0 & 0 & 0 & 0 & 0 & 0 & 0 \\
\hline Centroptilum & 0 & 0 & 0 & 0 & 0 & 0 & 0 & 0 & 0 & 0 & 0 & 0 & 0 & 0 & 0 & 0 & 0 & 0 \\
\hline Heptageniidae(UNK) & 0 & 0 & 0 & 0 & 2 & 0 & 0 & 0 & 0 & 0 & 0 & 0 & 0 & 2 & 0 & 0 & 0 & 0 \\
\hline Epeorus & 0 & 0 & 2 & 1 & 0 & 1 & 0 & 0 & 0 & 0 & 0 & 0 & 0 & 1 & 2 & 0 & 7 & 1 \\
\hline Heptagenia & 0 & 0 & 0 & 0 & 0 & 0 & 0 & 0 & 0 & 0 & 0 & 0 & 0 & 0 & 2 & 0 & 0 & 0 \\
\hline Stenonema/Maccaffertium & 0 & 0 & 0 & 0 & 0 & 0 & 0 & 0 & 0 & 0 & 0 & 0 & 0 & 3 & 0 & 0 & 0 & 0 \\
\hline Cinygmula & 0 & 0 & 0 & 0 & 0 & 0 & 0 & 0 & 0 & 0 & 0 & 0 & 0 & 0 & 0 & 0 & 0 & 0 \\
\hline Stenacron & 0 & 0 & 0 & 0 & 0 & 0 & 0 & 0 & 0 & 0 & 0 & 0 & 0 & 0 & 0 & 0 & 0 & 0 \\
\hline Isonychia & 0 & 0 & 0 & 1 & 0 & 0 & 0 & 0 & 0 & 0 & 0 & 0 & 0 & 0 & 0 & 0 & 0 & 0 \\
\hline Leptophelbiidae(UNK) & 0 & 0 & 0 & 0 & 2 & 0 & 0 & 0 & 0 & 0 & 0 & 0 & 0 & 8 & 0 & 0 & 0 & 5 \\
\hline Paraleptophlebia & 0 & 0 & 0 & 0 & 0 & 0 & 0 & 0 & 0 & 0 & 0 & 0 & 0 & 0 & 34 & 0 & 0 & 2 \\
\hline
\end{tabular}




\begin{tabular}{|c|c|c|c|c|c|c|c|c|c|c|c|c|c|c|c|c|c|c|}
\hline Ephemerellidae(UNK) & 0 & 0 & 0 & 0 & 0 & 1 & 0 & 0 & 0 & 0 & 0 & 0 & 0 & 3 & 0 & 0 & 0 & 0 \\
\hline Ephemerella & 0 & 0 & 0 & 0 & 3 & 5 & 0 & 0 & 0 & 0 & 0 & 0 & 0 & 5 & 3 & 0 & 0 & 11 \\
\hline Drunella & 0 & 0 & 0 & 0 & 0 & 2 & 0 & 0 & 0 & 0 & 0 & 0 & 0 & 3 & 0 & 0 & 0 & 2 \\
\hline Tricorythodes & 0 & 0 & 1 & 0 & 0 & 0 & 0 & 0 & 0 & 0 & 0 & 0 & 0 & 0 & 0 & 0 & 0 & 0 \\
\hline Ephemera & 0 & 0 & 0 & 0 & 0 & 1 & 0 & 0 & 0 & 0 & 0 & 0 & 0 & 0 & 0 & 0 & 0 & 0 \\
\hline Ameletus & 0 & 0 & 0 & 0 & 0 & 0 & 0 & 0 & 0 & 0 & 0 & 0 & 0 & 0 & 0 & 0 & 0 & 0 \\
\hline Unknown Mayfly & 0 & 0 & 0 & 0 & 0 & 1 & 0 & 0 & 0 & 0 & 0 & 0 & 0 & 3 & 18 & 0 & 4 & 2 \\
\hline Hydropsychidae(UNK) & 0 & 0 & 0 & 1 & 0 & 0 & 0 & 0 & 0 & 0 & 0 & 0 & 0 & 0 & 0 & 0 & 0 & 0 \\
\hline Hydropsyche & 1 & 0 & 0 & 0 & 5 & 1 & 0 & 0 & 1 & 6 & 0 & 2 & 9 & 0 & 0 & 0 & 0 & 0 \\
\hline Diplectrona & 0 & 6 & 0 & 0 & 0 & 2 & 3 & 4 & 2 & 11 & 2 & 0 & 14 & 1 & 13 & 1 & 3 & 1 \\
\hline Ceratopsyche & 3 & 2 & 10 & 3 & 0 & 0 & 0 & 0 & 0 & 0 & 0 & 0 & 0 & 7 & 0 & 0 & 0 & 2 \\
\hline Cheumatopsyche & 1 & 0 & 1 & 3 & 0 & 6 & 2 & 0 & 0 & 0 & 0 & 0 & 1 & 5 & 0 & 1 & 0 & 0 \\
\hline Wormaldia & 0 & 0 & 0 & 0 & 0 & 0 & 0 & 0 & 0 & 0 & 0 & 0 & 0 & 0 & 0 & 0 & 0 & 0 \\
\hline Chimarra & 0 & 0 & 2 & 0 & 1 & 0 & 0 & 0 & 0 & 0 & 0 & 0 & 1 & 1 & 0 & 0 & 0 & 0 \\
\hline Dolophilodes & 0 & 0 & 0 & 0 & 0 & 0 & 0 & 0 & 0 & 0 & 0 & 0 & 0 & 10 & 0 & 0 & 0 & 21 \\
\hline Rhyacophilla & 0 & 2 & 1 & 0 & 0 & 0 & 0 & 0 & 0 & 0 & 0 & 0 & 1 & 1 & 0 & 0 & 0 & 1 \\
\hline UNK (Polycentropodidae) & 0 & 0 & 1 & 0 & 0 & 0 & 0 & 0 & 0 & 1 & 0 & 1 & 0 & 0 & 0 & 0 & 0 & 0 \\
\hline Polycentropus & 5 & 0 & 0 & 2 & 0 & 0 & 0 & 0 & 0 & 0 & 0 & 0 & 0 & 0 & 1 & 1 & 1 & 0 \\
\hline Cyrnellus & 0 & 0 & 0 & 0 & 0 & 0 & 0 & 0 & 0 & 0 & 0 & 0 & 0 & 0 & 0 & 0 & 0 & 0 \\
\hline Lepidostoma & 0 & 0 & 0 & 0 & 0 & 0 & 0 & 0 & 1 & 0 & 0 & 0 & 0 & 0 & 0 & 0 & 0 & 0 \\
\hline Pycnopsyche & 0 & 0 & 0 & 0 & 0 & 0 & 0 & 1 & 0 & 0 & 0 & 0 & 0 & 0 & 0 & 0 & 0 & 1 \\
\hline Hydatophylax & 0 & 0 & 0 & 0 & 0 & 0 & 0 & 0 & 0 & 0 & 0 & 0 & 0 & 0 & 0 & 0 & 0 & 0 \\
\hline Leptoceridae(UNK) & 0 & 0 & 0 & 0 & 0 & 0 & 0 & 0 & 0 & 0 & 0 & 0 & 0 & 0 & 0 & 0 & 0 & 0 \\
\hline Hydroptilidae (UNK) & 1 & 0 & 0 & 0 & 0 & 0 & 0 & 0 & 0 & 0 & 0 & 0 & 0 & 0 & 0 & 0 & 0 & 0 \\
\hline Hydroptila & 0 & 0 & 0 & 0 & 0 & 5 & 0 & 0 & 0 & 0 & 0 & 0 & 0 & 1 & 0 & 0 & 0 & 0 \\
\hline Orthotrichia & 0 & 0 & 0 & 0 & 0 & 0 & 0 & 0 & 0 & 0 & 0 & 0 & 0 & 0 & 0 & 0 & 0 & 0 \\
\hline Ochrotrichia & 0 & 0 & 0 & 0 & 0 & 0 & 0 & 0 & 0 & 0 & 0 & 0 & 0 & 0 & 0 & 0 & 1 & 0 \\
\hline Agapetus & 0 & 0 & 0 & 0 & 0 & 1 & 0 & 0 & 0 & 0 & 0 & 0 & 0 & 0 & 2 & 0 & 6 & 0 \\
\hline Glossosoma & 0 & 0 & 0 & 0 & 0 & 0 & 0 & 0 & 0 & 0 & 0 & 0 & 0 & 0 & 0 & 0 & 0 & 0 \\
\hline Neophylax & 0 & 0 & 0 & 0 & 0 & 0 & 0 & 0 & 0 & 0 & 0 & 0 & 0 & 0 & 3 & 0 & 3 & 0 \\
\hline Phryganeidae(UNK) & 0 & 0 & 0 & 0 & 0 & 0 & 0 & 0 & 0 & 0 & 0 & 0 & 0 & 0 & 0 & 0 & 0 & 0 \\
\hline Unkown Caddisfly & 0 & 0 & 0 & 0 & 0 & 0 & 0 & 0 & 0 & 0 & 0 & 0 & 0 & 0 & 1 & 0 & 0 & 0 \\
\hline Chloroperlidae(UNK) & 0 & 0 & 0 & 0 & 0 & 0 & 0 & 0 & 0 & 0 & 0 & 0 & 0 & 0 & 0 & 0 & 0 & 0 \\
\hline
\end{tabular}




\begin{tabular}{|c|c|c|c|c|c|c|c|c|c|c|c|c|c|c|c|c|c|}
\hline Haploperla & 4 & 0 & 3 & 1 & 7 & 10 & 4 & 0 & 5 & 0 & 11 & 0 & 0 & 1 & 2 & 0 & 14 \\
\hline Sweltsa & 0 & 0 & 0 & 0 & 0 & 0 & 0 & 0 & 0 & 0 & 0 & 0 & 0 & 0 & 0 & 0 & 0 \\
\hline Alloperla & 3 & 2 & 0 & 0 & 0 & 3 & 0 & 0 & 0 & 0 & 0 & 0 & 0 & 0 & 0 & 0 & 0 \\
\hline Allocapnia & 0 & 0 & 0 & 0 & 0 & 0 & 0 & 0 & 0 & 0 & 0 & 0 & 0 & 0 & 0 & 0 & 0 \\
\hline Leuctra & 17 & 2 & 39 & 40 & 7 & 10 & 5 & 2 & 10 & 4 & 1 & 10 & 21 & 9 & 15 & 8 & 14 \\
\hline Acroneuria & 0 & 0 & 1 & 2 & 0 & 1 & 0 & 0 & 0 & 0 & 0 & 0 & 0 & 0 & 5 & 1 & 1 \\
\hline Agnetina & 0 & 0 & 0 & 0 & 0 & 0 & 0 & 0 & 0 & 0 & 0 & 0 & 0 & 0 & 0 & 0 & 0 \\
\hline Beloneuria & 0 & 0 & 0 & 0 & 0 & 0 & 0 & 0 & 0 & 0 & 0 & 0 & 0 & 0 & 0 & 0 & 0 \\
\hline Hansonoperla & 0 & 0 & 0 & 0 & 0 & 0 & 0 & 0 & 0 & 0 & 0 & 0 & 0 & 0 & 0 & 0 & 0 \\
\hline Paragnetina & 2 & 0 & 2 & 2 & 0 & 0 & 0 & 0 & 0 & 0 & 0 & 0 & 0 & 0 & 0 & 0 & 0 \\
\hline Pteronarcys & 0 & 0 & 0 & 0 & 0 & 0 & 0 & 0 & 0 & 0 & 0 & 0 & 0 & 0 & 0 & 0 & 0 \\
\hline Perlodidae(UNK) & 0 & 0 & 0 & 0 & 0 & 0 & 0 & 0 & 1 & 0 & 0 & 0 & 0 & 0 & 0 & 0 & 0 \\
\hline Isoperla & 0 & 0 & 0 & 1 & 0 & 3 & 0 & 0 & 0 & 0 & 0 & 0 & 0 & 1 & 0 & 0 & 0 \\
\hline Yugus & 0 & 0 & 0 & 0 & 0 & 0 & 0 & 0 & 0 & 0 & 0 & 0 & 0 & 0 & 0 & 0 & 3 \\
\hline Tallaperla & 0 & 0 & 0 & 0 & 0 & 0 & 0 & 0 & 1 & 0 & 0 & 0 & 0 & 0 & 0 & 0 & 0 \\
\hline Peltoperla & 0 & 0 & 0 & 0 & 0 & 0 & 0 & 0 & 0 & 0 & 0 & 0 & 0 & 2 & 0 & 0 & 0 \\
\hline Amphinemuera & 12 & 2 & 5 & 10 & 13 & 22 & 5 & 0 & 12 & 6 & 9 & 3 & 93 & 0 & 23 & 0 & 24 \\
\hline Paranemoura & 0 & 0 & 0 & 0 & 0 & 0 & 0 & 0 & 0 & 0 & 0 & 0 & 0 & 0 & 0 & 0 & 0 \\
\hline Taeniopteryx & 1 & 0 & 0 & 0 & 2 & 0 & 1 & 0 & 3 & 0 & 0 & 0 & 3 & 1 & 0 & 0 & 0 \\
\hline Taeniopterygidae(UNK) & 0 & 0 & 0 & 0 & 0 & 0 & 0 & 0 & 0 & 0 & 0 & 0 & 0 & 0 & 0 & 0 & 0 \\
\hline Unknown Stonefly & 6 & 0 & 0 & 5 & 5 & 1 & 0 & 0 & 2 & 4 & 14 & 0 & 0 & 2 & 2 & 0 & 0 \\
\hline Gomphidae(UNK) & 0 & 0 & 0 & 0 & 0 & 0 & 0 & 0 & 1 & 1 & 0 & 1 & 0 & 0 & 0 & 0 & 0 \\
\hline Lanthus & 0 & 0 & 0 & 0 & 0 & 1 & 0 & 0 & 0 & 0 & 0 & 0 & 0 & 0 & 0 & 0 & 0 \\
\hline Stylogomphus & 1 & 0 & 0 & 0 & 0 & 0 & 0 & 0 & 0 & 0 & 0 & 0 & 0 & 0 & 0 & 0 & 0 \\
\hline Aeshnidae (UNK) & 0 & 0 & 0 & 0 & 0 & 0 & 0 & 0 & 0 & 0 & 0 & 0 & 0 & 0 & 0 & 0 & 0 \\
\hline Boyeria & 0 & 0 & 0 & 2 & 0 & 0 & 0 & 0 & 0 & 0 & 0 & 0 & 0 & 0 & 0 & 0 & 0 \\
\hline Calopteryx & 1 & 0 & 0 & 0 & 0 & 0 & 0 & 0 & 0 & 0 & 0 & 0 & 0 & 0 & 0 & 0 & 0 \\
\hline Elmidae(UNK) & 0 & 0 & 0 & 0 & 1 & 0 & 0 & 0 & 0 & 0 & 0 & 0 & 0 & 6 & 0 & 0 & 2 \\
\hline Optioservus & 1 & 0 & 0 & 0 & 1 & 1 & 0 & 0 & 0 & 0 & 0 & 0 & 0 & 5 & 0 & 0 & 6 \\
\hline Promoresia & 0 & 0 & 1 & 1 & 0 & 0 & 0 & 0 & 0 & 0 & 0 & 0 & 0 & 0 & 0 & 0 & 0 \\
\hline Oulimnius & 0 & 0 & 0 & 0 & 1 & 0 & 1 & 0 & 0 & 0 & 0 & 0 & 1 & 2 & 0 & 0 & 6 \\
\hline Ancyronyx & 0 & 0 & 0 & 1 & 0 & 0 & 0 & 0 & 0 & 0 & 0 & 0 & 0 & 0 & 0 & 0 & 0 \\
\hline Stenelmis & 0 & 0 & 10 & 3 & 0 & 0 & 0 & 0 & 0 & 0 & 0 & 0 & 0 & 0 & 0 & 0 & 0 \\
\hline
\end{tabular}




\begin{tabular}{|c|c|c|c|c|c|c|c|c|c|c|c|c|c|c|c|c|c|c|}
\hline Dubiraphia & 1 & 0 & 0 & 0 & 0 & 3 & 0 & 0 & 0 & 0 & 0 & 0 & 0 & 0 & 0 & 0 & 0 & 0 \\
\hline Ectopria & 0 & 2 & 0 & 0 & 0 & 0 & 0 & 0 & 0 & 0 & 0 & 0 & 0 & 0 & 6 & 0 & 1 & 0 \\
\hline Psephenus & 0 & 0 & 0 & 0 & 0 & 0 & 0 & 0 & 0 & 0 & 0 & 0 & 0 & 1 & 0 & 0 & 0 & 0 \\
\hline Anchytarsus & 0 & 0 & 0 & 0 & 0 & 0 & 0 & 1 & 0 & 0 & 1 & 0 & 0 & 0 & 0 & 0 & 1 & 0 \\
\hline Curculionidae(UNK) & 1 & 0 & 0 & 0 & 0 & 0 & 0 & 0 & 0 & 0 & 0 & 0 & 0 & 0 & 0 & 0 & 0 & 0 \\
\hline Dytiscidae(UNK) & 0 & 0 & 0 & 0 & 0 & 0 & 0 & 0 & 0 & 0 & 0 & 0 & 0 & 0 & 0 & 0 & 0 & 0 \\
\hline Peltodytes & 0 & 0 & 0 & 0 & 0 & 0 & 0 & 0 & 0 & 0 & 0 & 0 & 0 & 0 & 0 & 0 & 0 & 0 \\
\hline Unknown Beetle & 0 & 0 & 0 & 0 & 0 & 0 & 0 & 0 & 0 & 0 & 0 & 0 & 0 & 0 & 0 & 0 & 0 & 0 \\
\hline Nigronia & 0 & 0 & 0 & 0 & 0 & 1 & 0 & 0 & 0 & 0 & 0 & 2 & 1 & 0 & 1 & 0 & 3 & 1 \\
\hline Sialis & 0 & 0 & 1 & 0 & 1 & 0 & 0 & 1 & 0 & 0 & 0 & 0 & 0 & 0 & 0 & 1 & 0 & 0 \\
\hline UNK & 1 & 0 & 0 & 0 & 0 & 0 & 0 & 0 & 0 & 0 & 0 & 0 & 0 & 0 & 0 & 0 & 0 & 0 \\
\hline Hemiptera (UNK) & 0 & 0 & 0 & 0 & 0 & 0 & 0 & 0 & 0 & 0 & 0 & 0 & 0 & 0 & 0 & 0 & 0 & 0 \\
\hline Mesovelia & 0 & 0 & 0 & 0 & 0 & 0 & 0 & 0 & 0 & 0 & 0 & 0 & 0 & 0 & 0 & 0 & 0 & 0 \\
\hline Chironomidae & 32 & 7 & 24 & 10 & 25 & 88 & 19 & 14 & 25 & 14 & 29 & 74 & 59 & 48 & 46 & 31 & 54 & 40 \\
\hline Tipulidae(UNK) & 0 & 0 & 0 & 0 & 0 & 0 & 0 & 0 & 0 & 0 & 0 & 0 & 0 & 2 & 0 & 0 & 1 & 0 \\
\hline Antocha & 0 & 0 & 0 & 0 & 0 & 0 & 0 & 0 & 0 & 0 & 0 & 0 & 0 & 0 & 2 & 0 & 1 & 0 \\
\hline Tipula & 0 & 0 & 1 & 0 & 0 & 1 & 0 & 0 & 0 & 0 & 1 & 1 & 1 & 0 & 2 & 1 & 0 & 0 \\
\hline Hexatoma & 2 & 0 & 3 & 1 & 2 & 5 & 0 & 0 & 0 & 0 & 0 & 0 & 0 & 0 & 3 & 0 & 0 & 1 \\
\hline Dicranota & 0 & 0 & 0 & 0 & 0 & 0 & 0 & 0 & 0 & 0 & 0 & 0 & 0 & 0 & 0 & 0 & 0 & 0 \\
\hline Molophilus & 5 & 3 & 0 & 0 & 0 & 0 & 0 & 0 & 0 & 0 & 0 & 0 & 0 & 0 & 1 & 0 & 0 & 0 \\
\hline Limnophila & 0 & 0 & 0 & 0 & 0 & 0 & 0 & 0 & 0 & 0 & 0 & 9 & 0 & 0 & 0 & 0 & 1 & 0 \\
\hline Pseudolimnophila & 0 & 0 & 0 & 0 & 0 & 0 & 0 & 0 & 0 & 0 & 0 & 0 & 0 & 0 & 2 & 0 & 5 & 0 \\
\hline Pedicia & 0 & 0 & 0 & 0 & 0 & 0 & 0 & 0 & 0 & 0 & 0 & 0 & 0 & 0 & 0 & 0 & 0 & 0 \\
\hline Limonia & 0 & 0 & 0 & 0 & 0 & 0 & 0 & 0 & 0 & 0 & 0 & 0 & 0 & 0 & 0 & 1 & 0 & 0 \\
\hline Chrysops & 0 & 0 & 0 & 0 & 0 & 0 & 0 & 0 & 0 & 0 & 0 & 0 & 0 & 0 & 1 & 0 & 0 & 0 \\
\hline Simuliidae(UNK) & 0 & 0 & 0 & 0 & 0 & 0 & 0 & 0 & 0 & 0 & 0 & 0 & 0 & 0 & 0 & 0 & 0 & 0 \\
\hline Simulium & 0 & 0 & 0 & 0 & 2 & 0 & 0 & 0 & 0 & 0 & 0 & 1 & 0 & 10 & 0 & 0 & 0 & 4 \\
\hline Prosimulium & 1 & 0 & 1 & 0 & 0 & 0 & 0 & 0 & 0 & 0 & 0 & 0 & 0 & 0 & 0 & 0 & 0 & 3 \\
\hline Empididae(UNK) & 0 & 0 & 0 & 0 & 0 & 0 & 0 & 0 & 0 & 0 & 0 & 0 & 0 & 0 & 0 & 0 & 0 & 0 \\
\hline Chelifera & 1 & 0 & 0 & 0 & 0 & 1 & 0 & 0 & 0 & 1 & 0 & 1 & 3 & 0 & 5 & 0 & 0 & 0 \\
\hline Clinocera & 0 & 0 & 0 & 0 & 0 & 0 & 0 & 0 & 0 & 0 & 1 & 4 & 0 & 0 & 0 & 0 & 0 & 0 \\
\hline Hemerodromia & 2 & 0 & 1 & 4 & 1 & 1 & 1 & 0 & 0 & 0 & 0 & 1 & 0 & 3 & 0 & 0 & 0 & 2 \\
\hline Ceratopogonidae(UNK) & 2 & 0 & 0 & 1 & 0 & 2 & 0 & 0 & 1 & 0 & 0 & 0 & 0 & 0 & 1 & 0 & 2 & 0 \\
\hline
\end{tabular}


Bezzia

Dasyhelea

Culicoides

Ceratopogon

Blepharicera

Psychodidae(UNK)

Unknown Diptera

Hydracarina

Collembola (UNK)

Bourletiella

Isotomorus

Isotomidae(UNK)

\begin{tabular}{|rrrrrrrrrr}
15 & 3 & 1 & 0 & 1 & 1 & 1 & 2 & 0 & 0 \\
4 & 0 & 0 & 1 & 3 & 4 & 5 & 0 & 0 & 0 \\
0 & 0 & 0 & 0 & 0 & 0 & 0 & 0 & 0 & 0 \\
1 & 0 & 0 & 0 & 0 & 2 & 0 & 0 & 0 & 0 \\
0 & 0 & 0 & 0 & 0 & 0 & 0 & 0 & 0 & 0 \\
0 & 0 & 0 & 0 & 0 & 0 & 0 & 0 & 0 & 0 \\
1 & 0 & 0 & 0 & 0 & 1 & 0 & 0 & 0 & 0 \\
0 & 0 & 1 & 1 & 0 & 5 & 0 & 0 & 0 & 0 \\
0 & 0 & 0 & 0 & 0 & 0 & 0 & 0 & 0 & 0 \\
0 & 0 & 0 & 0 & 0 & 0 & 0 & 0 & 1 & 1 \\
0 & 1 & 0 & 0 & 0 & 0 & 0 & 0 & 0 & 0 \\
0 & 0 & 0 & 0 & 0 & 0 & 0 & 0 & 0 & 0
\end{tabular}

$\begin{array}{llllllll}0 & 0 & 0 & 0 & 0 & 1 & 0 & 0 \\ 0 & 0 & 0 & 0 & 0 & 3 & 0 & 0 \\ 0 & 0 & 0 & 0 & 0 & 0 & 0 & 0 \\ 0 & 0 & 0 & 0 & 1 & 0 & 0 & 0 \\ 0 & 0 & 0 & 0 & 0 & 0 & 0 & 0 \\ 0 & 0 & 0 & 0 & 0 & 0 & 0 & 0 \\ 0 & 0 & 1 & 0 & 0 & 0 & 0 & 0 \\ 1 & 0 & 0 & 1 & 0 & 0 & 0 & 0 \\ 0 & 0 & 0 & 0 & 0 & 0 & 0 & 0 \\ 0 & 0 & 0 & 0 & 0 & 0 & 0 & 0 \\ 0 & 0 & 0 & 0 & 0 & 1 & 0 & 0 \\ 0 & 2 & 0 & 0 & 2 & 0 & 0 & 0\end{array}$


Appendix 5. Benthic macroinvertebrate data for Abram Creek by sample location in 2017. With the exception of Chironomidae, macroinvertebrates were identified to genus if possible. UNK=unknown.

\begin{tabular}{|c|c|c|c|c|c|c|c|c|c|c|c|c|c|c|c|c|c|c|}
\hline Site & 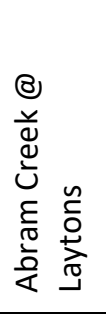 & $\begin{array}{l}\frac{c}{5} \\
\text { J } \\
\sum^{0} \\
8 \\
8 \\
气 \\
\frac{n}{0} \\
\frac{0}{0} \\
\frac{0}{2}\end{array}$ & $\begin{array}{l}\geq \\
\frac{Z}{0} \\
\frac{E}{U} \\
0 \\
0 \\
0 \\
\frac{0}{0} \\
\frac{E}{\pi} \\
\frac{0}{0}\end{array}$ & 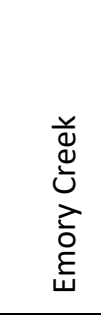 & $\begin{array}{l}\bar{\Phi} \\
\frac{1}{7} \\
0 \\
0 \\
0 \\
0 \\
0 \\
0 \\
\frac{0}{0} \\
\frac{E}{0} \\
\frac{0}{4}\end{array}$ & 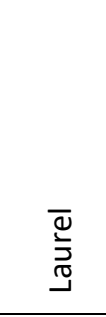 & $\begin{array}{l}\frac{0}{0} \\
\frac{\pi}{0} \\
0 \\
0 \\
0 \\
\frac{0}{0} \\
\frac{E}{0} \\
\frac{0}{0}\end{array}$ & $\begin{array}{l}\frac{0}{0} \\
\frac{\pi}{0}\end{array}$ & $\begin{array}{l}\cup \\
0 \\
0 \\
0 \\
0 \\
\frac{8}{0} \\
\frac{E}{0} \\
\frac{0}{4}\end{array}$ & $\begin{array}{l}x \\
\frac{x}{0} \\
\stackrel{5}{5} \\
8 \\
8 \\
\frac{E}{0} \\
\frac{0}{0}\end{array}$ & 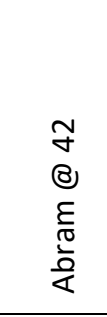 & 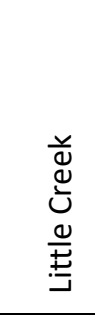 & 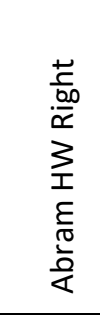 & 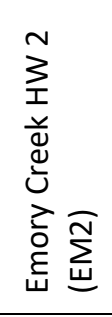 & 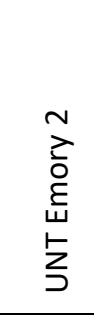 & 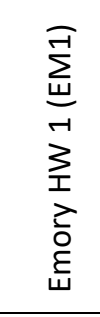 & 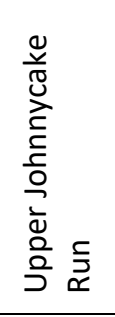 & 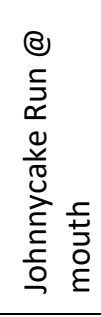 \\
\hline Year & 2017 & 2017 & 2017 & 2017 & 2017 & 2017 & 2017 & 2017 & 2017 & 2017 & 2017 & 2017 & 2017 & 2017 & 2017 & 2017 & 2017 & 2017 \\
\hline Oligochaeta & 0 & 0 & 0 & 0 & 0 & 0 & 0 & 0 & 0 & 0 & 0 & 0 & 0 & 0 & 0 & 0 & 0 & 0 \\
\hline Planorbidae & 0 & 0 & 0 & 0 & 0 & 0 & 0 & 0 & 0 & 0 & 0 & 0 & 0 & 0 & 0 & 0 & 0 & 0 \\
\hline Lymnaeidae & 0 & 0 & 0 & 0 & 0 & 0 & 0 & 0 & 0 & 0 & 0 & 0 & 0 & 0 & 0 & 0 & 0 & 0 \\
\hline Snails(UNK) & 0 & 0 & 0 & 0 & 0 & 0 & 0 & 0 & 0 & 0 & 0 & 0 & 0 & 0 & 0 & 0 & 0 & 0 \\
\hline Gammarus & 0 & 0 & 0 & 0 & 0 & 0 & 0 & 0 & 0 & 1 & 0 & 0 & 0 & 0 & 21 & 0 & 0 & 0 \\
\hline Caecidotea & 1 & 0 & 0 & 0 & 0 & 0 & 0 & 0 & 0 & 0 & 0 & 8 & 0 & 0 & 0 & 1 & 0 & 0 \\
\hline Baetidae(UNK) & 0 & 0 & 0 & 0 & 0 & 0 & 0 & 0 & 0 & 0 & 0 & 0 & 0 & 0 & 0 & 0 & 0 & 0 \\
\hline Accentrella & 3 & 22 & 4 & 2 & 3 & 5 & 3 & 6 & 7 & 0 & 4 & 0 & 2 & 2 & 0 & 3 & 0 & 8 \\
\hline Baetis & 1 & 4 & 1 & 1 & 0 & 4 & 4 & 44 & 2 & 0 & 1 & 0 & 0 & 82 & 38 & 26 & 16 & 10 \\
\hline Plauditus & 72 & 42 & 56 & 18 & 123 & 0 & 109 & 4 & 122 & 3 & 2 & 0 & 5 & 2 & 3 & 37 & 10 & 48 \\
\hline Heterocloeon & 0 & 6 & 0 & 0 & 3 & 0 & 1 & 0 & 1 & 0 & 0 & 0 & 0 & 0 & 0 & 0 & 0 & 0 \\
\hline Centroptilum & 0 & 0 & 0 & 0 & 0 & 0 & 0 & 0 & 1 & 0 & 0 & 0 & 0 & 0 & 0 & 0 & 0 & 0 \\
\hline Heptageniidae(UNK) & 0 & 0 & 0 & 0 & 0 & 0 & 0 & 0 & 0 & 0 & 0 & 0 & 0 & 0 & 0 & 0 & 0 & 0 \\
\hline Epeorus & 1 & 0 & 4 & 0 & 0 & 0 & 0 & 2 & 0 & 0 & 0 & 0 & 0 & 6 & 9 & 4 & 0 & 4 \\
\hline Heptagenia & 0 & 0 & 0 & 0 & 0 & 0 & 0 & 0 & 0 & 0 & 0 & 0 & 0 & 0 & 0 & 0 & 0 & 0 \\
\hline Stenonema/Maccaffertium & 0 & 1 & 1 & 0 & 0 & 0 & 0 & 0 & 0 & 0 & 0 & 0 & 0 & 0 & 0 & 1 & 0 & 5 \\
\hline Cinygmula & 0 & 0 & 0 & 0 & 0 & 0 & 0 & 0 & 0 & 0 & 0 & 0 & 0 & 0 & 0 & 0 & 0 & 0 \\
\hline Stenacron & 2 & 0 & 0 & 0 & 0 & 0 & 0 & 1 & 0 & 0 & 0 & 0 & 0 & 0 & 2 & 1 & 3 & 3 \\
\hline Isonychia & 0 & 0 & 0 & 0 & 0 & 0 & 0 & 0 & 0 & 0 & 0 & 0 & 0 & 0 & 0 & 0 & 0 & 0 \\
\hline Leptophelbiidae(UNK) & 0 & 0 & 0 & 0 & 0 & 0 & 0 & 0 & 0 & 0 & 0 & 0 & 0 & 0 & 0 & 0 & 0 & 0 \\
\hline Paraleptophlebia & 0 & 0 & 1 & 0 & 0 & 0 & 0 & 6 & 1 & 0 & 0 & 0 & 0 & 10 & 28 & 9 & 13 & 9 \\
\hline Ephemerellidae(UNK) & 0 & 0 & 0 & 0 & 0 & 0 & 0 & 0 & 0 & 0 & 0 & 0 & 0 & 0 & 0 & 0 & 0 & 0 \\
\hline
\end{tabular}




\begin{tabular}{|c|c|c|c|c|c|c|c|c|c|c|c|c|c|c|c|c|c|}
\hline Ephemerella & 0 & 0 & 1 & 0 & 1 & 0 & 0 & 1 & 0 & 0 & 0 & 0 & 0 & 1 & 4 & 0 & 3 \\
\hline Drunella & 0 & 0 & 1 & 0 & 0 & 0 & 0 & 4 & 0 & 0 & 0 & 0 & 0 & 0 & 0 & 0 & 2 \\
\hline Tricorythodes & 0 & 0 & 0 & 0 & 0 & 0 & 0 & 0 & 0 & 0 & 0 & 0 & 0 & 0 & 0 & 0 & 0 \\
\hline Ephemera & 0 & 0 & 0 & 0 & 0 & 0 & 0 & 0 & 0 & 0 & 0 & 0 & 0 & 0 & 0 & 0 & 0 \\
\hline Ameletus & 0 & 0 & 0 & 0 & 0 & 0 & 0 & 3 & 0 & 0 & 0 & 0 & 0 & 0 & 0 & 0 & 0 \\
\hline Unknown Mayfly & 0 & 0 & 0 & 0 & 0 & 0 & 0 & 0 & 0 & 0 & 0 & 0 & 0 & 0 & 0 & 0 & 0 \\
\hline Hydropsychidae(UNK) & 0 & 0 & 0 & 0 & 0 & 0 & 0 & 0 & 0 & 0 & 0 & 38 & 0 & 0 & 0 & 0 & 0 \\
\hline Hydropsyche & 4 & 3 & 2 & 1 & 0 & 0 & 4 & 1 & 1 & 1 & 4 & 0 & 7 & 0 & 0 & 1 & 0 \\
\hline Diplectrona & 0 & 0 & 0 & 2 & 4 & 3 & 3 & 0 & 1 & 0 & 2 & 0 & 0 & 3 & 4 & 0 & 4 \\
\hline Ceratopsyche & 0 & 0 & 0 & 0 & 0 & 0 & 0 & 0 & 0 & 0 & 0 & 0 & 0 & 0 & 0 & 0 & 0 \\
\hline Cheumatopsyche & 1 & 0 & 2 & 0 & 0 & 1 & 0 & 1 & 0 & 2 & 0 & 0 & 0 & 0 & 0 & 1 & 3 \\
\hline Wormaldia & 0 & 0 & 0 & 0 & 0 & 0 & 0 & 0 & 0 & 0 & 0 & 0 & 0 & 0 & 0 & 1 & 0 \\
\hline Chimarra & 0 & 0 & 0 & 0 & 0 & 0 & 0 & 0 & 0 & 0 & 0 & 0 & 0 & 0 & 0 & 0 & 0 \\
\hline Dolophilodes & 2 & 0 & 0 & 0 & 0 & 0 & 0 & 10 & 0 & 0 & 0 & 0 & 0 & 1 & 4 & 4 & 39 \\
\hline Rhyacophilla & 0 & 0 & 0 & 1 & 0 & 1 & 0 & 1 & 0 & 0 & 0 & 0 & 1 & 0 & 1 & 0 & 3 \\
\hline UNK (Polycentropodidae) & 0 & 0 & 0 & 0 & 0 & 0 & 0 & 0 & 0 & 0 & 0 & 0 & 0 & 0 & 0 & 0 & 0 \\
\hline Polycentropus & 0 & 2 & 2 & 2 & 0 & 1 & 2 & 0 & 0 & 0 & 0 & 0 & 0 & 1 & 0 & 0 & 0 \\
\hline Cyrnellus & 0 & 0 & 0 & 0 & 0 & 0 & 0 & 0 & 0 & 0 & 0 & 0 & 0 & 0 & 0 & 0 & 0 \\
\hline Lepidostoma & 0 & 0 & 0 & 0 & 0 & 0 & 0 & 0 & 0 & 0 & 0 & 0 & 0 & 0 & 0 & 0 & 0 \\
\hline Pycnopsyche & 0 & 0 & 0 & 0 & 0 & 0 & 0 & 0 & 0 & 0 & 0 & 0 & 0 & 0 & 0 & 0 & 0 \\
\hline Hydatophylax & 0 & 0 & 0 & 1 & 1 & 0 & 0 & 0 & 0 & 0 & 1 & 0 & 0 & 0 & 0 & 0 & 0 \\
\hline Leptoceridae(UNK) & 0 & 0 & 0 & 0 & 0 & 0 & 0 & 0 & 0 & 0 & 0 & 0 & 0 & 0 & 0 & 0 & 0 \\
\hline Hydroptilidae (UNK) & 0 & 0 & 0 & 0 & 0 & 0 & 0 & 0 & 0 & 0 & 0 & 0 & 0 & 0 & 0 & 0 & 0 \\
\hline Hydroptila & 0 & 0 & 0 & 0 & 0 & 0 & 0 & 0 & 0 & 0 & 0 & 0 & 0 & 0 & 0 & 0 & 0 \\
\hline Orthotrichia & 0 & 0 & 0 & 0 & 0 & 0 & 0 & 1 & 0 & 0 & 0 & 0 & 0 & 0 & 0 & 0 & 0 \\
\hline Ochrotrichia & 0 & 0 & 0 & 0 & 0 & 0 & 0 & 0 & 0 & 0 & 0 & 0 & 0 & 0 & 0 & 0 & 0 \\
\hline Agapetus & 0 & 0 & 0 & 0 & 0 & 0 & 0 & 0 & 0 & 0 & 0 & 0 & 0 & 3 & 1 & 0 & 0 \\
\hline Glossosoma & 0 & 0 & 0 & 0 & 0 & 0 & 0 & 0 & 0 & 0 & 0 & 0 & 0 & 0 & 0 & 0 & 1 \\
\hline Neophylax & 0 & 0 & 0 & 0 & 0 & 0 & 0 & 0 & 0 & 0 & 0 & 0 & 0 & 0 & 0 & 0 & 0 \\
\hline Phryganeidae(UNK) & 0 & 0 & 0 & 0 & 0 & 0 & 0 & 0 & 0 & 0 & 0 & 1 & 0 & 0 & 0 & 0 & 0 \\
\hline Unkown Caddisfly & 0 & 0 & 0 & 0 & 0 & 0 & 0 & 0 & 0 & 0 & 0 & 0 & 0 & 0 & 0 & 0 & 0 \\
\hline Chloroperlidae(UNK) & 0 & 0 & 0 & 0 & 0 & 0 & 0 & 0 & 0 & 0 & 0 & 0 & 0 & 0 & 0 & 0 & 0 \\
\hline Haploperla & 0 & 0 & 0 & 0 & 0 & 0 & 0 & 0 & 0 & 0 & 0 & 0 & 0 & 0 & 0 & 0 & 0 \\
\hline
\end{tabular}




\begin{tabular}{|c|c|c|c|c|c|c|c|c|c|c|c|c|c|c|c|c|c|}
\hline Sweltsa & 0 & 0 & 0 & 0 & 1 & 0 & 0 & 0 & 0 & 0 & 0 & 0 & 0 & 0 & 0 & 1 & 0 \\
\hline Alloperla & 0 & 0 & 0 & 0 & 0 & 0 & 0 & 0 & 2 & 0 & 0 & 0 & 0 & 0 & 0 & 0 & 0 \\
\hline Allocapnia & 0 & 0 & 0 & 0 & 1 & 0 & 0 & 0 & 0 & 0 & 0 & 0 & 7 & 0 & 0 & 4 & 0 \\
\hline Leuctra & 70 & 74 & 59 & 7 & 11 & 2 & 10 & 45 & 8 & 1 & 15 & 55 & 46 & 20 & 13 & 20 & 19 \\
\hline Acroneuria & 10 & 1 & 11 & 0 & 0 & 0 & 0 & 2 & 0 & 0 & 0 & 0 & 0 & 3 & 2 & 2 & 0 \\
\hline Agnetina & 0 & 0 & 0 & 0 & 0 & 0 & 0 & 1 & 0 & 0 & 0 & 0 & 0 & 0 & 0 & 0 & 0 \\
\hline Beloneuria & 0 & 0 & 0 & 0 & 0 & 0 & 0 & 0 & 0 & 0 & 0 & 0 & 0 & 0 & 0 & 0 & 1 \\
\hline Hansonoperla & 0 & 0 & 0 & 0 & 0 & 0 & 0 & 0 & 0 & 0 & 0 & 0 & 0 & 0 & 0 & 0 & 0 \\
\hline Paragnetina & 1 & 12 & 0 & 0 & 0 & 0 & 0 & 0 & 0 & 0 & 0 & 0 & 0 & 0 & 0 & 0 & 0 \\
\hline Pteronarcys & 0 & 0 & 0 & 0 & 0 & 0 & 0 & 0 & 0 & 0 & 0 & 0 & 0 & 0 & 0 & 0 & 1 \\
\hline Perlodidae(UNK) & 0 & 0 & 0 & 0 & 0 & 0 & 0 & 0 & 0 & 0 & 0 & 0 & 0 & 0 & 0 & 0 & 5 \\
\hline Isoperla & 0 & 1 & 7 & 5 & 2 & 0 & 1 & 1 & 3 & 0 & 2 & 0 & 1 & 4 & 0 & 3 & 0 \\
\hline Yugus & 0 & 0 & 0 & 0 & 0 & 0 & 0 & 0 & 0 & 0 & 0 & 0 & 0 & 0 & 0 & 0 & 1 \\
\hline Tallaperla & 0 & 0 & 0 & 0 & 1 & 0 & 1 & 1 & 0 & 0 & 0 & 0 & 0 & 1 & 1 & 1 & 10 \\
\hline Peltoperla & 0 & 0 & 0 & 0 & 0 & 0 & 0 & 0 & 0 & 0 & 0 & 0 & 0 & 0 & 0 & 0 & 0 \\
\hline Amphinemuera & 1 & 2 & 5 & 10 & 16 & 1 & 8 & 0 & 8 & 0 & 3 & 0 & 74 & 15 & 6 & 14 & 0 \\
\hline Paranemoura & 0 & 0 & 0 & 0 & 0 & 0 & 0 & 0 & 0 & 0 & 0 & 0 & 0 & 0 & 0 & 0 & 0 \\
\hline Taeniopteryx & 0 & 0 & 0 & 0 & 0 & 0 & 0 & 0 & 0 & 0 & 0 & 0 & 0 & 0 & 0 & 0 & 0 \\
\hline Taeniopterygidae(UNK) & 0 & 0 & 0 & 0 & 0 & 0 & 0 & 0 & 0 & 0 & 0 & 0 & 0 & 0 & 0 & 0 & 0 \\
\hline Unknown Stonefly & 0 & 0 & 0 & 0 & 0 & 0 & 0 & 0 & 0 & 0 & 0 & 0 & 0 & 0 & 0 & 0 & 0 \\
\hline Gomphidae(UNK) & 0 & 0 & 0 & 0 & 0 & 0 & 0 & 0 & 0 & 0 & 0 & 0 & 0 & 0 & 0 & 0 & 0 \\
\hline Lanthus & 3 & 0 & 1 & 0 & 0 & 0 & 1 & 0 & 0 & 0 & 0 & 0 & 0 & 0 & 0 & 0 & 0 \\
\hline Stylogomphus & 0 & 0 & 0 & 0 & 0 & 0 & 0 & 0 & 0 & 0 & 0 & 0 & 0 & 0 & 0 & 0 & 0 \\
\hline Aeshnidae (UNK) & 0 & 0 & 1 & 0 & 0 & 0 & 0 & 0 & 0 & 0 & 0 & 0 & 0 & 0 & 0 & 0 & 0 \\
\hline Boyeria & 0 & 0 & 0 & 0 & 2 & 0 & 0 & 0 & 0 & 0 & 0 & 0 & 0 & 0 & 0 & 0 & 0 \\
\hline Calopteryx & 0 & 0 & 0 & 0 & 0 & 0 & 0 & 0 & 0 & 0 & 0 & 0 & 0 & 0 & 0 & 0 & 0 \\
\hline Elmidae(UNK) & 0 & 0 & 0 & 0 & 0 & 0 & 0 & 0 & 0 & 0 & 0 & 0 & 0 & 0 & 0 & 0 & 0 \\
\hline Optioservus & 8 & 9 & 8 & 0 & 0 & 0 & 0 & 0 & 1 & 1 & 0 & 0 & 0 & 0 & 0 & 4 & 4 \\
\hline Promoresia & 0 & 0 & 0 & 0 & 0 & 0 & 0 & 0 & 0 & 0 & 0 & 0 & 0 & 0 & 0 & 0 & 2 \\
\hline Oulimnius & 0 & 0 & 0 & 0 & 1 & 0 & 0 & 1 & 0 & 0 & 0 & 0 & 0 & 10 & 1 & 11 & 4 \\
\hline Ancyronyx & 0 & 0 & 0 & 0 & 0 & 0 & 0 & 0 & 0 & 0 & 0 & 0 & 0 & 0 & 0 & 0 & 0 \\
\hline Stenelmis & 1 & 0 & 0 & 0 & 0 & 0 & 0 & 0 & 0 & 0 & 0 & 0 & 0 & 0 & 0 & 0 & 1 \\
\hline Dubiraphia & 0 & 0 & 0 & 0 & 0 & 0 & 0 & 0 & 0 & 0 & 0 & 0 & 0 & 0 & 0 & 0 & 0 \\
\hline
\end{tabular}


Ectopria

Psephenus

Anchytarsus

Curculionidae(UNK)

Dytiscidae(UNK)

Peltodytes

Unknown Beetle

\section{Nigronia}

Sialis

UNK

Hemiptera (UNK)

Mesovelia

Chironomidae

Tipulidae(UNK)

Antocha

Tipula

Hexatoma

Dicranota

Molophilus

Limnophila

Pseudolimnophila

Pedicia

Limonia

Chrysops

Simuliidae(UNK)

Simulium

Prosimulium

Empididae(UNK)

Chelifera

Clinocera

Hemerodromia

Ceratopogonidae(UNK)

\begin{tabular}{|c|c|c|c|c|c|c|c|c|c|c|c|c|c|c|c|c|}
\hline 0 & 0 & 0 & 0 & 0 & 0 & 0 & 0 & 0 & 0 & 0 & 0 & 0 & 1 & 0 & 1 & 2 \\
\hline 2 & 1 & 0 & 0 & 0 & 0 & 0 & 0 & 0 & 0 & 0 & 0 & 0 & 0 & 0 & 0 & 0 \\
\hline 0 & 0 & 0 & 0 & 0 & 0 & 0 & 0 & 0 & 0 & 0 & 0 & 0 & 0 & 0 & 0 & 0 \\
\hline 0 & 0 & 0 & 0 & 0 & 0 & 0 & 0 & 0 & 0 & 0 & 0 & 0 & 0 & 0 & 0 & 0 \\
\hline 0 & 0 & 0 & 0 & 0 & 0 & 0 & 0 & 0 & 0 & 0 & 1 & 0 & 0 & 0 & 0 & 0 \\
\hline 0 & 0 & 0 & 1 & 0 & 0 & 0 & 0 & 0 & 0 & 0 & 0 & 0 & 0 & 0 & 0 & 0 \\
\hline 0 & 0 & 0 & 0 & 0 & 0 & 0 & 0 & 0 & 0 & 0 & 0 & 0 & 0 & 0 & 0 & 0 \\
\hline 0 & 0 & 0 & 0 & 1 & 0 & 0 & 0 & 1 & 0 & 0 & 0 & 0 & 0 & 0 & 0 & 0 \\
\hline 0 & 0 & 0 & 1 & 0 & 2 & 0 & 0 & 1 & 1 & 0 & 0 & 0 & 0 & 0 & 0 & 0 \\
\hline 0 & 0 & 0 & 0 & 0 & 0 & 0 & 0 & 0 & 0 & 0 & 0 & 0 & 0 & 0 & 0 & 0 \\
\hline 0 & 0 & 1 & 0 & 0 & 0 & 0 & 0 & 0 & 0 & 0 & 0 & 0 & 0 & 0 & 0 & 0 \\
\hline 0 & 0 & 0 & 0 & 0 & 0 & 1 & 0 & 0 & 0 & 0 & 0 & 0 & 0 & 0 & 0 & 0 \\
\hline 15 & 13 & 15 & 26 & 11 & 6 & 37 & 54 & 19 & 19 & 4 & 72 & 47 & 32 & 42 & 33 & 30 \\
\hline 0 & 0 & 0 & 0 & 0 & 1 & 0 & 0 & 0 & 0 & 0 & 0 & 0 & 0 & 0 & 0 & 0 \\
\hline 0 & 0 & 0 & 0 & 0 & 0 & 0 & 0 & 0 & 0 & 0 & 0 & 0 & 0 & 0 & 0 & 0 \\
\hline 0 & 1 & 1 & 1 & 0 & 0 & 0 & 0 & 0 & 0 & 4 & 0 & 0 & 2 & 0 & 0 & 1 \\
\hline 5 & 1 & 2 & 1 & 0 & 0 & 0 & 0 & 0 & 0 & 0 & 1 & 0 & 0 & 0 & 0 & 0 \\
\hline 0 & 0 & 0 & 0 & 0 & 0 & 0 & 0 & 0 & 0 & 0 & 0 & 0 & 0 & 0 & 0 & 2 \\
\hline 0 & 0 & 0 & 0 & 0 & 0 & 0 & 0 & 0 & 0 & 0 & 0 & 0 & 0 & 0 & 0 & 0 \\
\hline 0 & 0 & 1 & 0 & 0 & 0 & 0 & 0 & 0 & 0 & 0 & 5 & 0 & 0 & 4 & 3 & 0 \\
\hline 0 & 0 & 0 & 0 & 0 & 0 & 0 & 0 & 0 & 0 & 0 & 0 & 0 & 0 & 0 & 0 & 0 \\
\hline 0 & 0 & 0 & 0 & 0 & 0 & 0 & 1 & 0 & 0 & 0 & 0 & 11 & 0 & 0 & 0 & 0 \\
\hline 0 & 0 & 0 & 0 & 0 & 0 & 0 & 0 & 0 & 0 & 0 & 0 & 0 & 0 & 0 & 0 & 0 \\
\hline 0 & 0 & 0 & 0 & 0 & 0 & 0 & 0 & 0 & 0 & 0 & 0 & 0 & 0 & 0 & 0 & 0 \\
\hline 0 & 0 & 0 & 0 & 0 & 0 & 0 & 0 & 0 & 4 & 0 & 0 & 0 & 0 & 0 & 0 & 4 \\
\hline 0 & 0 & 0 & 0 & 0 & 0 & 0 & 0 & 0 & 0 & 0 & 0 & 0 & 0 & 0 & 0 & 0 \\
\hline 0 & 0 & 0 & 0 & 0 & 0 & 0 & 0 & 0 & 0 & 0 & 0 & 0 & 0 & 0 & 0 & 0 \\
\hline 0 & 0 & 0 & 0 & 0 & 0 & 0 & 0 & 0 & 0 & 1 & 0 & 0 & 0 & 0 & 0 & 0 \\
\hline 0 & 0 & 0 & 0 & 0 & 0 & 0 & 0 & 0 & 0 & 0 & 0 & 0 & 0 & 0 & 0 & 0 \\
\hline 0 & 0 & 0 & 0 & 0 & 0 & 0 & 0 & 0 & 0 & 0 & 0 & 0 & 0 & 0 & 0 & 0 \\
\hline 0 & 0 & 0 & 0 & 0 & 0 & 0 & 2 & 0 & 5 & 1 & 0 & 0 & 0 & 0 & 0 & 0 \\
\hline 0 & 0 & 0 & 3 & 0 & 0 & 0 & 0 & 0 & 2 & 0 & 0 & 0 & 3 & 0 & 0 & 0 \\
\hline 0 & 0 & 0 & 0 & 0 & 0 & 0 & 0 & 0 & 0 & 0 & 0 & 0 & 0 & 0 & 0 & 0 \\
\hline
\end{tabular}


Dasyhelea

Culicoides

Ceratopogon

Blepharicera

Psychodidae(UNK)

Unknown Diptera

Hydracarina

Collembola (UNK)

Bourletiella

Isotomorus

Isotomidae(UNK)

$\begin{array}{lllllll}0 & 0 & 0 & 0 & 0 & 0 & 0 \\ 0 & 0 & 0 & 0 & 0 & 0 & 0 \\ 0 & 0 & 0 & 0 & 0 & 0 & 0 \\ 0 & 1 & 0 & 0 & 0 & 0 & 0 \\ 0 & 0 & 0 & 0 & 0 & 0 & 0 \\ 0 & 0 & 0 & 0 & 0 & 0 & 0 \\ 0 & 0 & 0 & 0 & 0 & 0 & 0 \\ 0 & 0 & 0 & 0 & 0 & 0 & 0 \\ 0 & 0 & 0 & 0 & 0 & 0 & 0 \\ 0 & 0 & 0 & 0 & 0 & 0 & 0 \\ 0 & 0 & 0 & 0 & 0 & 0 & 0\end{array}$

0
0
0
0
0
0
0
0
0
0
0

0
0
0
0
0
0
0
0
0

0
0
0
0
0
0
0
0
0
0
0

$\begin{array}{ll}0 & 0 \\ 0 & 0 \\ 0 & 0 \\ 0 & 0 \\ 0 & 0 \\ 0 & 0 \\ 1 & 0 \\ 0 & 0 \\ 0 & 0 \\ 0 & 0\end{array}$

0
0
0
0
0
0
0
0
0
0
0

$\begin{array}{lllll}0 & 0 & 0 & 0 & 0 \\ 0 & 0 & 0 & 0 & 0 \\ 0 & 0 & 0 & 0 & 0 \\ 0 & 0 & 0 & 0 & 0 \\ 0 & 0 & 0 & 0 & 0 \\ 0 & 0 & 0 & 0 & 0 \\ 0 & 0 & 0 & 0 & 0 \\ 0 & 0 & 0 & 0 & 0 \\ 0 & 0 & 0 & 0 & 0 \\ 0 & 0 & 0 & 0 & 0 \\ 0 & 0 & 0 & 0 & 0\end{array}$


Appendix 6. Benthic macroinvertebrate data for Three Fork Creek by sample location in 2008. With the exception of Chironomidae, macroinvertebrates were identified to genus if possible. UNK=unknown.

\begin{tabular}{|c|c|c|c|c|c|c|c|c|c|c|c|c|c|c|}
\hline Site & 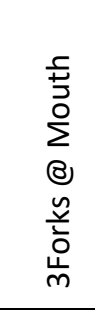 & 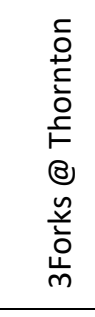 & 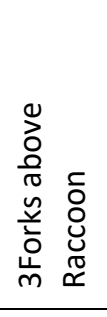 & 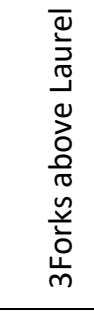 & 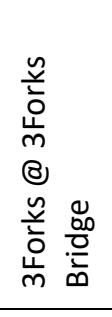 & 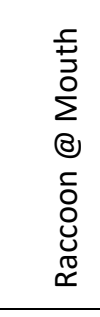 & 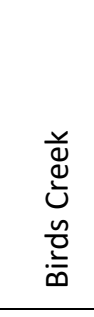 & 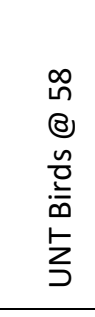 & 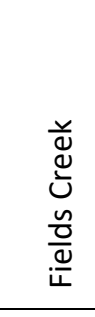 & 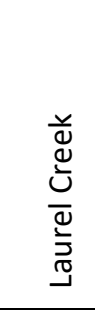 & 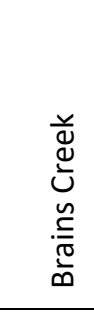 & $\begin{array}{l}\text { Dे } \\
\text { ठิ }\end{array}$ & 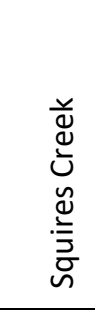 & 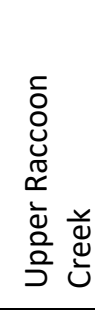 \\
\hline Year & 2008 & 2008 & 2008 & 2008 & 2008 & 2008 & 2008 & 2008 & 2008 & 2008 & 2008 & 2008 & 2008 & 2008 \\
\hline Turbellaria & 0 & 0 & 0 & 0 & 0 & 0 & 0 & 0 & 0 & 0 & 0 & 0 & 0 & 0 \\
\hline Oligochaeta & 0 & 0 & 0 & 0 & 0 & 0 & 0 & 0 & 0 & 0 & 0 & 0 & 0 & 0 \\
\hline Aeolosomatidae & 0 & 0 & 0 & 0 & 0 & 0 & 0 & 0 & 0 & 0 & 0 & 0 & 0 & 0 \\
\hline Nematoda & 0 & 0 & 0 & 0 & 0 & 0 & 0 & 0 & 0 & 0 & 0 & 0 & 0 & 0 \\
\hline Nemertea & 0 & 0 & 0 & 0 & 0 & 0 & 0 & 0 & 0 & 0 & 0 & 0 & 0 & 0 \\
\hline Hirudinea & 0 & 0 & 0 & 0 & 0 & 0 & 0 & 0 & 0 & 0 & 0 & 0 & 0 & 0 \\
\hline Corbiculidae & 0 & 0 & 0 & 0 & 0 & 0 & 0 & 0 & 0 & 0 & 0 & 0 & 0 & 0 \\
\hline Sphaeriidae & 0 & 0 & 0 & 0 & 0 & 0 & 0 & 0 & 0 & 0 & 0 & 0 & 0 & 0 \\
\hline Unionidae & 0 & 0 & 0 & 0 & 0 & 0 & 0 & 0 & 0 & 0 & 0 & 0 & 0 & 0 \\
\hline Clams & 0 & 0 & 0 & 0 & 0 & 0 & 0 & 0 & 0 & 0 & 0 & 0 & 0 & 0 \\
\hline Ancylidae & 0 & 0 & 0 & 0 & 0 & 0 & 0 & 0 & 0 & 0 & 0 & 0 & 0 & 0 \\
\hline Planorbidae & 0 & 0 & 0 & 0 & 0 & 0 & 0 & 0 & 0 & 0 & 0 & 0 & 0 & 0 \\
\hline Physidae & 0 & 0 & 0 & 0 & 0 & 0 & 0 & 0 & 0 & 0 & 0 & 0 & 0 & 0 \\
\hline Lymnaeidae & 0 & 0 & 0 & 0 & 0 & 0 & 0 & 0 & 0 & 0 & 0 & 0 & 0 & 0 \\
\hline Snails(UNK) & 0 & 0 & 0 & 0 & 0 & 0 & 0 & 0 & 0 & 0 & 0 & 0 & 0 & 0 \\
\hline Cambarus & 0 & 0 & 0 & 0 & 0 & 0 & 0 & 0 & 0 & 0 & 0 & 0 & 0 & 0 \\
\hline Orconectes & 0 & 0 & 0 & 0 & 0 & 0 & 0 & 0 & 0 & 0 & 0 & 0 & 0 & 0 \\
\hline Gammarus & 0 & 0 & 0 & 0 & 0 & 0 & 0 & 0 & 0 & 0 & 0 & 0 & 1 & 0 \\
\hline Hyalella & 0 & 0 & 0 & 0 & 0 & 0 & 0 & 0 & 0 & 0 & 0 & 0 & 0 & 0 \\
\hline Crangonyx & 0 & 0 & 0 & 0 & 0 & 0 & 0 & 0 & 0 & 0 & 0 & 0 & 0 & 0 \\
\hline Stygobromus & 0 & 0 & 0 & 0 & 0 & 0 & 0 & 0 & 0 & 0 & 0 & 0 & 0 & 0 \\
\hline Asellidae(UNK) & 0 & 0 & 0 & 0 & 0 & 0 & 0 & 0 & 0 & 0 & 0 & 0 & 0 & 0 \\
\hline Caecidotea & 0 & 0 & 0 & 0 & 0 & 0 & 0 & 0 & 0 & 0 & 0 & 0 & 0 & 0 \\
\hline
\end{tabular}




\begin{tabular}{|c|c|c|c|c|c|c|c|c|c|c|c|c|c|}
\hline Lirceus & 0 & 0 & 0 & 0 & 0 & 0 & 0 & 0 & 0 & 0 & 0 & 0 & 0 \\
\hline Baetidae(UNK) & 0 & 0 & 0 & 0 & 0 & 0 & 0 & 0 & 3 & 0 & 1 & 13 & 0 \\
\hline Accentrella & 0 & 0 & 0 & 0 & 0 & 0 & 0 & 0 & 23 & 14 & 0 & 19 & 0 \\
\hline Baetis & 0 & 14 & 0 & 0 & 0 & 0 & 0 & 0 & 22 & 13 & 0 & 6 & 0 \\
\hline Plauditus & 0 & 0 & 0 & 0 & 0 & 0 & 0 & 0 & 29 & 10 & 0 & 18 & 0 \\
\hline Procloeon & 0 & 0 & 0 & 0 & 0 & 0 & 0 & 0 & 0 & 0 & 0 & 0 & 0 \\
\hline Acerpenna & 0 & 0 & 0 & 0 & 0 & 0 & 0 & 0 & 0 & 0 & 0 & 0 & 0 \\
\hline Diphetor & 0 & 0 & 0 & 0 & 0 & 0 & 0 & 0 & 0 & 0 & 0 & 0 & 0 \\
\hline Heterocloeon & 0 & 0 & 0 & 0 & 0 & 0 & 0 & 0 & 0 & 0 & 0 & 0 & 0 \\
\hline Centroptilum & 0 & 0 & 0 & 0 & 0 & 0 & 0 & 0 & 0 & 0 & 0 & 0 & 0 \\
\hline Caenis & 0 & 0 & 0 & 0 & 0 & 0 & 0 & 0 & 0 & 0 & 0 & 0 & 0 \\
\hline Heptageniidae(UNK) & 0 & 0 & 0 & 0 & 0 & 0 & 0 & 0 & 0 & 1 & 0 & 4 & 0 \\
\hline Epeorus & 0 & 0 & 0 & 0 & 0 & 0 & 0 & 0 & 0 & 0 & 0 & 0 & 0 \\
\hline Heptagenia & 0 & 0 & 0 & 0 & 0 & 0 & 0 & 0 & 0 & 0 & 0 & 0 & 0 \\
\hline Stenonema/Maccaffertium & 0 & 0 & 0 & 0 & 0 & 0 & 0 & 0 & 0 & 0 & 0 & 1 & 0 \\
\hline Cinygmula & 0 & 0 & 0 & 0 & 0 & 0 & 0 & 0 & 0 & 0 & 0 & 0 & 0 \\
\hline Stenacron & 0 & 0 & 0 & 0 & 0 & 0 & 0 & 0 & 0 & 0 & 0 & 2 & 0 \\
\hline Leucrocuta & 0 & 0 & 0 & 0 & 0 & 0 & 0 & 0 & 0 & 0 & 0 & 0 & 0 \\
\hline Isonychia & 0 & 0 & 0 & 0 & 0 & 0 & 0 & 0 & 0 & 0 & 0 & 0 & 0 \\
\hline Leptophelbiidae(UNK) & 0 & 0 & 0 & 0 & 0 & 0 & 0 & 0 & 0 & 0 & 0 & 0 & 0 \\
\hline Paraleptophlebia & 0 & 0 & 0 & 0 & 0 & 0 & 0 & 0 & 1 & 4 & 0 & 0 & 0 \\
\hline Leptophlebia & 0 & 0 & 0 & 0 & 0 & 0 & 0 & 0 & 0 & 0 & 0 & 0 & 0 \\
\hline Habrophlebiodes & 0 & 0 & 0 & 0 & 0 & 0 & 0 & 0 & 0 & 0 & 0 & 0 & 0 \\
\hline Ephemerellidae(UNK) & 0 & 0 & 0 & 0 & 0 & 0 & 0 & 0 & 0 & 0 & 0 & 0 & 0 \\
\hline Ephemerella & 0 & 1 & 0 & 0 & 0 & 0 & 0 & 0 & 0 & 9 & 0 & 0 & 0 \\
\hline Serratella & 0 & 0 & 0 & 0 & 0 & 0 & 0 & 0 & 0 & 0 & 0 & 0 & 0 \\
\hline Drunella & 0 & 0 & 0 & 0 & 0 & 0 & 0 & 0 & 0 & 0 & 0 & 0 & 0 \\
\hline Dannella & 0 & 0 & 0 & 0 & 0 & 0 & 0 & 0 & 0 & 0 & 0 & 0 & 0 \\
\hline Eurylophella & 0 & 0 & 0 & 0 & 0 & 0 & 0 & 0 & 0 & 2 & 0 & 0 & 0 \\
\hline Attenella & 0 & 0 & 0 & 0 & 0 & 0 & 0 & 0 & 0 & 0 & 0 & 0 & 0 \\
\hline Siphlonuridae & 0 & 0 & 0 & 0 & 0 & 0 & 0 & 0 & 0 & 0 & 0 & 0 & 0 \\
\hline Tricorythodes & 0 & 0 & 0 & 0 & 0 & 0 & 0 & 0 & 0 & 0 & 0 & 0 & 0 \\
\hline Ephemera & 0 & 0 & 0 & 0 & 0 & 0 & 0 & 0 & 0 & 0 & 0 & 0 & 0 \\
\hline
\end{tabular}




\begin{tabular}{|c|c|c|c|c|c|c|c|c|c|c|c|c|c|}
\hline Hexagenia & 0 & 0 & 0 & 0 & 0 & 0 & 0 & 0 & 0 & 0 & 0 & 0 & 0 \\
\hline Ameletus & 0 & 0 & 0 & 0 & 0 & 0 & 0 & 0 & 0 & 0 & 0 & 0 & 0 \\
\hline Neoephemeridae & 0 & 0 & 0 & 0 & 0 & 0 & 0 & 0 & 0 & 0 & 0 & 0 & 0 \\
\hline Oligoneuriidae & 0 & 0 & 0 & 0 & 0 & 0 & 0 & 0 & 0 & 0 & 0 & 0 & 0 \\
\hline Baetisca & 0 & 0 & 0 & 0 & 0 & 0 & 0 & 0 & 0 & 0 & 0 & 0 & 0 \\
\hline Unknown Mayfly & 0 & 0 & 0 & 0 & 0 & 0 & 0 & 0 & 0 & 0 & 0 & 0 & 0 \\
\hline Hydropsychidae(UNK) & 0 & 0 & 0 & 0 & 0 & 0 & 0 & 0 & 0 & 0 & 0 & 0 & 0 \\
\hline Parapsyche & 0 & 0 & 0 & 0 & 0 & 0 & 0 & 0 & 0 & 0 & 0 & 0 & 0 \\
\hline Hydropsyche & 0 & 0 & 0 & 1 & 0 & 0 & 0 & 0 & 0 & 0 & 3 & 1 & 0 \\
\hline Diplectrona & 0 & 0 & 0 & 1 & 0 & 0 & 0 & 0 & 0 & 0 & 0 & 0 & 0 \\
\hline Ceratopsyche & 0 & 0 & 0 & 0 & 0 & 0 & 0 & 0 & 1 & 0 & 0 & 0 & 0 \\
\hline Cheumatopsyche & 0 & 0 & 0 & 0 & 0 & 0 & 0 & 0 & 3 & 0 & 0 & 5 & 0 \\
\hline Philopotamidae(UNK) & 0 & 0 & 0 & 0 & 0 & 0 & 0 & 0 & 0 & 0 & 0 & 0 & 0 \\
\hline Wormaldia & 0 & 0 & 0 & 0 & 0 & 0 & 0 & 0 & 0 & 1 & 0 & 0 & 0 \\
\hline Chimarra & 0 & 0 & 0 & 0 & 0 & 0 & 0 & 0 & 0 & 0 & 0 & 0 & 0 \\
\hline Dolophilodes & 0 & 0 & 0 & 0 & 0 & 0 & 1 & 0 & 5 & 28 & 0 & 24 & 0 \\
\hline Rhyacophilla & 0 & 0 & 0 & 0 & 0 & 0 & 0 & 0 & 0 & 0 & 0 & 0 & 0 \\
\hline UNK (Polycentropodidae) & 0 & 0 & 1 & 0 & 0 & 1 & 0 & 0 & 1 & 1 & 1 & 0 & 0 \\
\hline Polycentropus & 0 & 0 & 0 & 0 & 0 & 0 & 0 & 0 & 0 & 0 & 0 & 0 & 0 \\
\hline Cernotina & 0 & 0 & 0 & 0 & 0 & 0 & 0 & 0 & 0 & 0 & 1 & 0 & 0 \\
\hline Cyrnellus & 0 & 0 & 0 & 0 & 0 & 0 & 0 & 0 & 0 & 0 & 0 & 0 & 0 \\
\hline Lepidostoma & 0 & 0 & 0 & 0 & 0 & 0 & 0 & 0 & 0 & 0 & 0 & 0 & 0 \\
\hline Limnephilidae(UNK) & 0 & 0 & 0 & 0 & 0 & 0 & 0 & 0 & 0 & 0 & 0 & 0 & 0 \\
\hline Pseudostenophylax & 0 & 0 & 0 & 0 & 0 & 0 & 0 & 0 & 0 & 0 & 0 & 0 & 0 \\
\hline Ironoquia & 0 & 0 & 0 & 0 & 0 & 0 & 0 & 0 & 0 & 0 & 0 & 0 & 0 \\
\hline Apatania & 0 & 0 & 0 & 0 & 0 & 0 & 0 & 0 & 0 & 0 & 0 & 0 & 0 \\
\hline Pycnopsyche & 0 & 0 & 0 & 0 & 0 & 0 & 0 & 0 & 0 & 0 & 0 & 0 & 0 \\
\hline Hydatophylax & 0 & 0 & 0 & 0 & 0 & 0 & 0 & 0 & 0 & 0 & 0 & 0 & 0 \\
\hline Goera & 0 & 0 & 0 & 0 & 0 & 0 & 0 & 0 & 0 & 0 & 0 & 0 & 0 \\
\hline Leptoceridae(UNK) & 0 & 0 & 0 & 0 & 0 & 0 & 0 & 0 & 0 & 0 & 0 & 0 & 0 \\
\hline Ceraclea & 0 & 0 & 0 & 0 & 0 & 0 & 0 & 0 & 0 & 0 & 0 & 0 & 0 \\
\hline Oecetis & 0 & 0 & 0 & 0 & 0 & 0 & 0 & 0 & 0 & 0 & 0 & 0 & 0 \\
\hline Odontoceridae & 0 & 0 & 0 & 0 & 0 & 0 & 0 & 0 & 0 & 0 & 0 & 0 & 0 \\
\hline
\end{tabular}




\begin{tabular}{|c|c|c|c|c|c|c|c|c|c|c|c|c|c|}
\hline Hydroptilidae (UNK) & 0 & 0 & 0 & 0 & 0 & 0 & 0 & 0 & 0 & 0 & 0 & 0 & 0 \\
\hline Hydroptila & 0 & 0 & 0 & 0 & 0 & 0 & 0 & 0 & 0 & 0 & 0 & 0 & 0 \\
\hline Orthotrichia & 0 & 0 & 0 & 0 & 0 & 0 & 0 & 0 & 0 & 0 & 0 & 0 & 0 \\
\hline Ochrotrichia & 0 & 0 & 0 & 0 & 0 & 0 & 0 & 0 & 0 & 0 & 0 & 0 & 0 \\
\hline Palaeagapetus & 0 & 0 & 0 & 0 & 0 & 0 & 0 & 0 & 0 & 0 & 0 & 0 & 0 \\
\hline Stactobiella & 0 & 0 & 0 & 0 & 0 & 0 & 0 & 0 & 1 & 0 & 0 & 4 & 0 \\
\hline Leucotrichia & 0 & 0 & 0 & 0 & 0 & 0 & 0 & 0 & 0 & 0 & 0 & 0 & 0 \\
\hline Oxyethira & 0 & 0 & 0 & 0 & 0 & 0 & 0 & 0 & 0 & 0 & 0 & 0 & 0 \\
\hline Agapetus & 0 & 0 & 0 & 0 & 0 & 0 & 0 & 0 & 0 & 0 & 0 & 0 & 0 \\
\hline Glossosoma & 0 & 0 & 0 & 0 & 0 & 0 & 0 & 0 & 0 & 1 & 0 & 0 & 0 \\
\hline Brachycentrus & 0 & 0 & 0 & 0 & 0 & 0 & 0 & 0 & 0 & 0 & 0 & 0 & 0 \\
\hline Helicopsychidae & 0 & 0 & 0 & 0 & 0 & 0 & 0 & 0 & 0 & 0 & 0 & 0 & 0 \\
\hline Lype & 0 & 0 & 0 & 0 & 0 & 0 & 0 & 0 & 0 & 0 & 0 & 0 & 0 \\
\hline Psychomyia & 0 & 0 & 0 & 0 & 0 & 0 & 0 & 0 & 0 & 0 & 0 & 0 & 0 \\
\hline Neophylax & 0 & 0 & 0 & 0 & 0 & 0 & 0 & 0 & 0 & 0 & 0 & 0 & 0 \\
\hline Molanna & 0 & 0 & 0 & 0 & 0 & 0 & 0 & 0 & 0 & 0 & 0 & 0 & 0 \\
\hline Phryganeidae(UNK) & 0 & 0 & 0 & 0 & 0 & 0 & 0 & 0 & 0 & 0 & 0 & 0 & 0 \\
\hline Unkown Caddisfly & 0 & 0 & 0 & 0 & 0 & 0 & 0 & 0 & 0 & 1 & 0 & 0 & 0 \\
\hline Chloroperlidae(UNK) & 0 & 0 & 0 & 0 & 0 & 0 & 0 & 0 & 0 & 0 & 0 & 0 & 0 \\
\hline Haploperla & 0 & 0 & 0 & 0 & 0 & 0 & 0 & 0 & 0 & 3 & 0 & 0 & 0 \\
\hline Utaperla & 0 & 0 & 0 & 0 & 0 & 0 & 0 & 0 & 0 & 0 & 0 & 0 & 0 \\
\hline Sweltsa & 0 & 0 & 0 & 0 & 0 & 0 & 0 & 0 & 0 & 0 & 0 & 0 & 0 \\
\hline Suwallia & 0 & 0 & 0 & 0 & 0 & 0 & 0 & 0 & 0 & 0 & 0 & 0 & 0 \\
\hline Alloperla & 0 & 0 & 0 & 0 & 0 & 0 & 0 & 0 & 3 & 0 & 0 & 0 & 0 \\
\hline Capniidae(UNK) & 0 & 0 & 0 & 0 & 0 & 0 & 0 & 0 & 0 & 0 & 0 & 0 & 0 \\
\hline Paracapnia & 0 & 0 & 0 & 0 & 0 & 0 & 0 & 0 & 0 & 0 & 0 & 0 & 0 \\
\hline Capnia & 0 & 0 & 0 & 0 & 0 & 0 & 0 & 0 & 0 & 0 & 0 & 0 & 0 \\
\hline Allocapnia & 0 & 0 & 0 & 0 & 0 & 0 & 0 & 0 & 0 & 0 & 0 & 0 & 0 \\
\hline Leuctridae(UNK) & 0 & 0 & 0 & 0 & 0 & 0 & 0 & 0 & 0 & 0 & 0 & 0 & 0 \\
\hline Paraleuctra & 0 & 0 & 0 & 0 & 0 & 0 & 0 & 0 & 0 & 0 & 0 & 0 & 0 \\
\hline Leuctra & 0 & 2 & 0 & 2 & 0 & 1 & 3 & 11 & 10 & 13 & 12 & 18 & 0 \\
\hline Zealeuctra & 0 & 0 & 0 & 0 & 0 & 0 & 0 & 0 & 0 & 0 & 0 & 0 & 0 \\
\hline Perlidae(UNK) & 0 & 0 & 0 & 0 & 0 & 0 & 0 & 0 & 0 & 0 & 0 & 0 & 0 \\
\hline
\end{tabular}




\begin{tabular}{|c|c|c|c|c|c|c|c|c|c|c|c|c|c|}
\hline Acroneuria & 0 & 0 & 0 & 0 & 0 & 0 & 0 & 0 & 3 & 4 & 0 & 0 & 0 \\
\hline Agnetina & 0 & 0 & 0 & 0 & 0 & 0 & 0 & 0 & 0 & 0 & 0 & 0 & 0 \\
\hline Eccoptura & 0 & 0 & 0 & 0 & 0 & 0 & 0 & 0 & 0 & 0 & 0 & 0 & 0 \\
\hline Beloneuria & 0 & 0 & 0 & 0 & 0 & 0 & 0 & 0 & 0 & 0 & 0 & 0 & 0 \\
\hline Hansonoperla & 0 & 0 & 0 & 0 & 0 & 0 & 0 & 0 & 0 & 0 & 0 & 0 & 0 \\
\hline Claassenia & 0 & 0 & 0 & 0 & 0 & 0 & 0 & 0 & 0 & 0 & 0 & 0 & 0 \\
\hline Neoperla & 0 & 0 & 0 & 0 & 0 & 0 & 0 & 0 & 0 & 0 & 0 & 0 & 0 \\
\hline Paragnetina & 0 & 0 & 0 & 0 & 0 & 0 & 0 & 0 & 0 & 0 & 0 & 0 & 0 \\
\hline Attaneuria & 0 & 0 & 0 & 0 & 0 & 0 & 0 & 0 & 0 & 0 & 0 & 0 & 0 \\
\hline Perlesta & 0 & 0 & 0 & 0 & 0 & 0 & 0 & 0 & 0 & 0 & 0 & 0 & 0 \\
\hline Pteronarcys & 0 & 0 & 0 & 0 & 0 & 0 & 0 & 0 & 0 & 0 & 0 & 0 & 0 \\
\hline Perlodidae(UNK) & 0 & 0 & 0 & 0 & 0 & 0 & 0 & 0 & 0 & 0 & 0 & 0 & 0 \\
\hline Isoperla & 0 & 0 & 0 & 0 & 0 & 0 & 0 & 0 & 0 & 1 & 0 & 0 & 0 \\
\hline Diura & 0 & 0 & 0 & 0 & 0 & 0 & 0 & 0 & 0 & 0 & 0 & 0 & 0 \\
\hline Cultus & 0 & 0 & 0 & 0 & 0 & 0 & 0 & 0 & 0 & 0 & 0 & 0 & 0 \\
\hline Remenus & 0 & 0 & 0 & 0 & 0 & 0 & 0 & 0 & 0 & 0 & 0 & 0 & 0 \\
\hline Malirekus & 0 & 0 & 0 & 0 & 0 & 0 & 0 & 0 & 0 & 0 & 0 & 0 & 0 \\
\hline Diploperla & 0 & 0 & 0 & 0 & 0 & 0 & 0 & 0 & 0 & 0 & 0 & 0 & 0 \\
\hline Yugus & 0 & 0 & 0 & 0 & 0 & 0 & 0 & 0 & 0 & 0 & 0 & 0 & 0 \\
\hline Tallaperla & 0 & 0 & 0 & 0 & 1 & 1 & 0 & 0 & 0 & 0 & 0 & 0 & 0 \\
\hline Peltoperla & 0 & 1 & 0 & 0 & 0 & 0 & 0 & 0 & 0 & 0 & 0 & 0 & 0 \\
\hline Viehoperla & 0 & 0 & 0 & 0 & 0 & 0 & 0 & 0 & 0 & 0 & 0 & 0 & 0 \\
\hline Soyedina & 0 & 0 & 0 & 0 & 0 & 0 & 0 & 0 & 0 & 0 & 0 & 0 & 0 \\
\hline Amphinemuera & 0 & 1 & 0 & 0 & 0 & 0 & 1 & 0 & 4 & 0 & 0 & 3 & 1 \\
\hline Ostrocerca & 0 & 0 & 0 & 0 & 0 & 0 & 0 & 0 & 0 & 0 & 0 & 0 & 0 \\
\hline Zapada & 0 & 0 & 0 & 0 & 0 & 0 & 0 & 0 & 0 & 0 & 0 & 0 & 0 \\
\hline Paranemoura & 0 & 0 & 0 & 0 & 0 & 0 & 0 & 0 & 0 & 0 & 0 & 0 & 0 \\
\hline Shipsa & 0 & 0 & 0 & 0 & 0 & 0 & 0 & 0 & 0 & 0 & 0 & 0 & 0 \\
\hline Taeniopteryx & 0 & 0 & 0 & 0 & 0 & 0 & 0 & 0 & 0 & 0 & 0 & 0 & 0 \\
\hline Taeniopterygidae(UNK) & 0 & 0 & 0 & 0 & 0 & 0 & 0 & 0 & 0 & 0 & 0 & 0 & 0 \\
\hline Unknown Stonefly & 0 & 1 & 0 & 0 & 0 & 0 & 0 & 0 & 0 & 0 & 0 & 0 & 0 \\
\hline Gomphidae(UNK) & 0 & 0 & 0 & 0 & 0 & 0 & 0 & 0 & 0 & 0 & 0 & 0 & 0 \\
\hline Gomphus & 0 & 0 & 0 & 0 & 0 & 0 & 0 & 0 & 0 & 0 & 0 & 0 & 0 \\
\hline
\end{tabular}




\begin{tabular}{|c|c|c|c|c|c|c|c|c|c|c|c|c|c|}
\hline Lanthus & 0 & 0 & 0 & 0 & 0 & 0 & 0 & 0 & 0 & 0 & 0 & 0 & 0 \\
\hline Progomphus & 0 & 0 & 0 & 0 & 0 & 0 & 0 & 0 & 0 & 0 & 0 & 0 & 0 \\
\hline Stylogomphus & 0 & 0 & 0 & 0 & 0 & 0 & 0 & 0 & 0 & 0 & 0 & 0 & 0 \\
\hline Dromogomphus & 0 & 0 & 0 & 0 & 0 & 0 & 0 & 0 & 0 & 0 & 0 & 0 & 0 \\
\hline Arigomphus & 0 & 0 & 0 & 0 & 0 & 0 & 0 & 0 & 0 & 0 & 0 & 0 & 0 \\
\hline Cordulegaster & 0 & 0 & 0 & 0 & 0 & 0 & 0 & 0 & 0 & 0 & 0 & 0 & 0 \\
\hline Aeshnidae (UNK) & 0 & 0 & 0 & 0 & 0 & 0 & 0 & 0 & 0 & 0 & 0 & 0 & 0 \\
\hline Aeshna & 0 & 0 & 0 & 0 & 0 & 0 & 0 & 0 & 0 & 0 & 0 & 0 & 0 \\
\hline Boyeria & 0 & 0 & 0 & 0 & 0 & 0 & 0 & 0 & 0 & 0 & 0 & 0 & 0 \\
\hline Epiaeschna & 0 & 0 & 0 & 0 & 0 & 0 & 0 & 0 & 0 & 0 & 0 & 0 & 0 \\
\hline Calopteryx & 0 & 0 & 0 & 0 & 0 & 0 & 0 & 0 & 0 & 0 & 0 & 0 & 0 \\
\hline Calopterygidae(UNK) & 0 & 0 & 0 & 0 & 0 & 0 & 0 & 0 & 0 & 0 & 0 & 0 & 0 \\
\hline Libellulidae & 0 & 0 & 0 & 0 & 0 & 0 & 0 & 0 & 0 & 0 & 0 & 0 & 0 \\
\hline Cornagrion & 0 & 0 & 0 & 0 & 0 & 0 & 0 & 0 & 0 & 0 & 0 & 0 & 0 \\
\hline Argia & 0 & 0 & 0 & 0 & 0 & 0 & 0 & 0 & 0 & 0 & 0 & 0 & 0 \\
\hline Coenagrionidae(UNK) & 0 & 0 & 0 & 0 & 0 & 0 & 0 & 0 & 0 & 0 & 0 & 0 & 0 \\
\hline Lestes & 0 & 0 & 0 & 0 & 0 & 0 & 0 & 0 & 0 & 0 & 0 & 0 & 0 \\
\hline Unkown Dragonfly & 0 & 0 & 0 & 1 & 0 & 1 & 0 & 0 & 0 & 0 & 0 & 0 & 0 \\
\hline Elmidae(UNK) & 0 & 0 & 0 & 0 & 0 & 0 & 0 & 0 & 0 & 0 & 0 & 0 & 0 \\
\hline Optioservus & 1 & 3 & 2 & 0 & 0 & 1 & 0 & 0 & 11 & 9 & 0 & 3 & 1 \\
\hline Promoresia & 0 & 0 & 0 & 0 & 0 & 0 & 0 & 0 & 0 & 1 & 0 & 0 & 0 \\
\hline Gonielmis & 0 & 0 & 0 & 0 & 0 & 0 & 0 & 0 & 0 & 0 & 0 & 0 & 0 \\
\hline Oulimnius & 0 & 1 & 0 & 1 & 0 & 0 & 1 & 0 & 1 & 3 & 0 & 0 & 0 \\
\hline Ancyronyx & 0 & 0 & 0 & 0 & 0 & 0 & 0 & 0 & 0 & 0 & 0 & 0 & 0 \\
\hline Microcylloepus & 0 & 0 & 0 & 0 & 0 & 0 & 0 & 0 & 0 & 0 & 0 & 0 & 0 \\
\hline Macronychus & 0 & 0 & 0 & 0 & 0 & 0 & 0 & 0 & 0 & 0 & 0 & 0 & 0 \\
\hline Stenelmis & 0 & 1 & 0 & 0 & 0 & 0 & 0 & 0 & 2 & 0 & 0 & 0 & 0 \\
\hline Dubiraphia & 0 & 0 & 0 & 0 & 0 & 0 & 0 & 0 & 0 & 0 & 0 & 0 & 0 \\
\hline Psephenidae(UNK) & 0 & 0 & 0 & 0 & 0 & 0 & 0 & 0 & 0 & 0 & 0 & 0 & 0 \\
\hline Ectopria & 0 & 1 & 0 & 0 & 0 & 0 & 0 & 0 & 0 & 1 & 0 & 0 & 0 \\
\hline Psephenus & 0 & 1 & 0 & 0 & 0 & 0 & 0 & 0 & 1 & 0 & 0 & 0 & 0 \\
\hline Dicranopselaphus & 0 & 0 & 0 & 0 & 0 & 0 & 0 & 0 & 0 & 0 & 0 & 0 & 0 \\
\hline Donacia & 0 & 0 & 0 & 0 & 0 & 0 & 0 & 0 & 0 & 0 & 0 & 0 & 0 \\
\hline
\end{tabular}




\begin{tabular}{|c|c|c|c|c|c|c|c|c|c|c|c|c|c|}
\hline Pyrrhalta & 0 & 0 & 0 & 0 & 0 & 0 & 0 & 0 & 0 & 0 & 0 & 0 & 0 \\
\hline Hydrothassa & 0 & 0 & 0 & 0 & 0 & 0 & 0 & 0 & 0 & 0 & 0 & 0 & 0 \\
\hline Disonycha & 0 & 0 & 0 & 0 & 0 & 0 & 0 & 0 & 0 & 0 & 0 & 0 & 0 \\
\hline Anchytarsus & 0 & 0 & 0 & 0 & 0 & 0 & 0 & 0 & 0 & 0 & 0 & 0 & 0 \\
\hline Curculionidae(UNK) & 0 & 0 & 0 & 0 & 0 & 0 & 0 & 0 & 0 & 0 & 0 & 0 & 0 \\
\hline Steremnius & 0 & 0 & 0 & 0 & 0 & 0 & 0 & 0 & 0 & 0 & 0 & 0 & 0 \\
\hline Dytiscidae(UNK) & 0 & 0 & 0 & 0 & 0 & 0 & 0 & 0 & 0 & 0 & 0 & 0 & 0 \\
\hline Celina & 0 & 0 & 0 & 0 & 0 & 0 & 0 & 0 & 0 & 0 & 0 & 0 & 0 \\
\hline Agabus & 0 & 0 & 0 & 0 & 0 & 0 & 0 & 0 & 0 & 0 & 0 & 0 & 0 \\
\hline Hydrovatus & 0 & 0 & 0 & 0 & 0 & 0 & 0 & 0 & 0 & 0 & 0 & 0 & 0 \\
\hline Staphylinidae(UNK) & 0 & 0 & 0 & 0 & 0 & 0 & 0 & 0 & 0 & 0 & 0 & 0 & 0 \\
\hline Peltodytes & 0 & 0 & 0 & 0 & 0 & 0 & 0 & 0 & 0 & 0 & 0 & 0 & 0 \\
\hline Carabidae(UNK) & 0 & 0 & 0 & 0 & 0 & 0 & 0 & 0 & 0 & 0 & 0 & 0 & 0 \\
\hline Hydrophilidae(UNK) & 0 & 0 & 0 & 0 & 0 & 0 & 0 & 0 & 0 & 0 & 0 & 0 & 0 \\
\hline Hydrochus & 0 & 0 & 0 & 0 & 0 & 0 & 0 & 0 & 0 & 0 & 0 & 0 & 0 \\
\hline Hydrophilus & 0 & 0 & 0 & 0 & 0 & 0 & 0 & 0 & 0 & 0 & 0 & 0 & 0 \\
\hline Crenitis & 0 & 0 & 0 & 0 & 0 & 0 & 0 & 0 & 0 & 0 & 0 & 0 & 0 \\
\hline Tropisternus & 0 & 0 & 0 & 0 & 0 & 0 & 0 & 0 & 0 & 0 & 0 & 0 & 0 \\
\hline Hydrobius & 0 & 0 & 0 & 0 & 0 & 0 & 0 & 0 & 0 & 0 & 0 & 0 & 0 \\
\hline Laccobius & 0 & 0 & 0 & 0 & 0 & 0 & 0 & 0 & 0 & 0 & 0 & 0 & 0 \\
\hline Berosus & 0 & 0 & 0 & 0 & 0 & 0 & 0 & 0 & 0 & 0 & 0 & 0 & 0 \\
\hline Georyssidae & 0 & 0 & 0 & 0 & 0 & 0 & 0 & 0 & 0 & 0 & 0 & 0 & 0 \\
\hline Helichus & 0 & 0 & 0 & 0 & 0 & 0 & 0 & 0 & 0 & 0 & 0 & 0 & 0 \\
\hline Dineutus & 0 & 0 & 0 & 0 & 0 & 0 & 0 & 0 & 0 & 0 & 0 & 0 & 0 \\
\hline Tenebrionidae & 0 & 0 & 0 & 0 & 0 & 0 & 0 & 0 & 0 & 0 & 0 & 0 & 0 \\
\hline Helophoridae & 0 & 0 & 0 & 0 & 0 & 0 & 0 & 0 & 0 & 0 & 0 & 0 & 0 \\
\hline Noteridae(UNK) & 0 & 0 & 0 & 0 & 0 & 0 & 0 & 0 & 0 & 0 & 0 & 0 & 0 \\
\hline Lutrochus & 0 & 0 & 0 & 0 & 0 & 0 & 0 & 0 & 0 & 0 & 0 & 0 & 0 \\
\hline Unknown Beetle & 0 & 0 & 0 & 0 & 0 & 0 & 0 & 0 & 0 & 0 & 0 & 0 & 0 \\
\hline Nigronia & 0 & 1 & 0 & 0 & 0 & 0 & 0 & 3 & 0 & 0 & 0 & 1 & 0 \\
\hline Corydalus & 0 & 0 & 0 & 0 & 0 & 0 & 0 & 0 & 0 & 0 & 0 & 0 & 0 \\
\hline Sialis & 0 & 0 & 0 & 0 & 1 & 0 & 0 & 0 & 0 & 0 & 0 & 0 & 0 \\
\hline Crambus & 0 & 0 & 0 & 0 & 0 & 0 & 0 & 0 & 0 & 0 & 0 & 0 & 0 \\
\hline
\end{tabular}




\begin{tabular}{|c|c|c|c|c|c|c|c|c|c|c|c|c|c|c|}
\hline Pyralidae(UNK) & 0 & 0 & 0 & 0 & 0 & 0 & 0 & 0 & 0 & 0 & 0 & 0 & 0 & 0 \\
\hline Cossidae & 0 & 0 & 0 & 0 & 0 & 0 & 0 & 0 & 0 & 0 & 0 & 0 & 0 & 0 \\
\hline Simyra & 0 & 0 & 0 & 0 & 0 & 0 & 0 & 0 & 0 & 0 & 0 & 0 & 0 & 0 \\
\hline Tortricidae(UNK) & 0 & 0 & 0 & 0 & 0 & 0 & 0 & 0 & 0 & 0 & 0 & 0 & 0 & 0 \\
\hline UNK & 0 & 0 & 0 & 0 & 0 & 0 & 0 & 0 & 0 & 0 & 0 & 0 & 0 & 0 \\
\hline Hemiptera (UNK) & 0 & 0 & 0 & 0 & 0 & 0 & 0 & 0 & 0 & 0 & 0 & 0 & 0 & 0 \\
\hline Corixidae & 0 & 0 & 0 & 0 & 0 & 0 & 0 & 0 & 0 & 0 & 0 & 0 & 0 & 0 \\
\hline UNK (Gerridae) & 0 & 0 & 0 & 0 & 0 & 0 & 0 & 0 & 0 & 0 & 0 & 0 & 0 & 0 \\
\hline Trepobates & 0 & 0 & 0 & 0 & 0 & 0 & 0 & 0 & 0 & 0 & 0 & 0 & 0 & 0 \\
\hline Saldidae & 0 & 0 & 0 & 1 & 0 & 0 & 0 & 0 & 0 & 0 & 0 & 0 & 0 & 0 \\
\hline Veliidae (UNK) & 0 & 0 & 0 & 0 & 0 & 0 & 0 & 0 & 0 & 0 & 0 & 0 & 0 & 0 \\
\hline Rhagovelia & 0 & 0 & 0 & 0 & 0 & 0 & 0 & 0 & 0 & 0 & 0 & 0 & 0 & 0 \\
\hline Microvelia & 0 & 0 & 0 & 0 & 0 & 0 & 0 & 0 & 0 & 0 & 0 & 0 & 0 & 0 \\
\hline Mesovelia & 0 & 0 & 0 & 0 & 0 & 0 & 0 & 0 & 0 & 0 & 0 & 0 & 0 & 0 \\
\hline Hebrus & 0 & 0 & 0 & 0 & 0 & 0 & 0 & 0 & 0 & 0 & 0 & 0 & 0 & 0 \\
\hline Merragata & 0 & 0 & 0 & 0 & 0 & 0 & 0 & 0 & 0 & 0 & 0 & 0 & 0 & 0 \\
\hline Chironomidae & 2 & 181 & 1 & 60 & 4 & 62 & 185 & 174 & 52 & 61 & 14 & 34 & 178 & 34 \\
\hline Tipulidae(UNK) & 0 & 1 & 0 & 0 & 0 & 0 & 0 & 0 & 0 & 0 & 0 & 0 & 0 & 0 \\
\hline Antocha & 0 & 0 & 0 & 0 & 0 & 0 & 0 & 0 & 0 & 0 & 0 & 0 & 0 & 0 \\
\hline Prionocera & 0 & 0 & 0 & 0 & 0 & 0 & 0 & 0 & 0 & 0 & 0 & 0 & 0 & 0 \\
\hline Tipula & 0 & 0 & 0 & 0 & 0 & 0 & 0 & 0 & 0 & 0 & 1 & 0 & 0 & 0 \\
\hline Hexatoma & 0 & 0 & 0 & 0 & 0 & 0 & 0 & 0 & 0 & 1 & 0 & 0 & 0 & 0 \\
\hline Dicranota & 0 & 0 & 0 & 0 & 0 & 0 & 0 & 0 & 2 & 0 & 0 & 0 & 0 & 0 \\
\hline Rhabdomastix & 0 & 0 & 0 & 0 & 0 & 0 & 0 & 0 & 0 & 0 & 0 & 0 & 0 & 0 \\
\hline Molophilus & 0 & 0 & 0 & 0 & 0 & 0 & 0 & 0 & 0 & 0 & 0 & 0 & 0 & 0 \\
\hline Limnophila & 0 & 1 & 0 & 0 & 0 & 0 & 0 & 0 & 2 & 0 & 0 & 3 & 0 & 0 \\
\hline Pilaria & 0 & 0 & 0 & 0 & 0 & 0 & 0 & 0 & 0 & 0 & 0 & 0 & 0 & 0 \\
\hline Leptotarsus & 0 & 0 & 0 & 0 & 0 & 0 & 0 & 0 & 0 & 0 & 0 & 0 & 0 & 0 \\
\hline Cryptolabis & 0 & 0 & 0 & 0 & 0 & 0 & 0 & 0 & 0 & 0 & 0 & 0 & 0 & 0 \\
\hline Pseudolimnophila & 0 & 0 & 0 & 0 & 0 & 0 & 0 & 0 & 0 & 0 & 0 & 0 & 0 & 0 \\
\hline Pedicia & 0 & 0 & 0 & 0 & 0 & 0 & 0 & 0 & 0 & 0 & 0 & 0 & 0 & 0 \\
\hline Brachypremna & 0 & 0 & 0 & 0 & 0 & 0 & 0 & 0 & 0 & 0 & 0 & 0 & 0 & 0 \\
\hline Erioptera & 0 & 0 & 0 & 0 & 0 & 0 & 0 & 0 & 0 & 0 & 0 & 0 & 0 & 0 \\
\hline
\end{tabular}




\begin{tabular}{|c|c|c|c|c|c|c|c|c|c|c|c|c|c|}
\hline Limonia & 0 & 0 & 0 & 0 & 0 & 0 & 0 & 0 & 0 & 0 & 0 & 0 & 0 \\
\hline Tabanus & 0 & 0 & 0 & 0 & 0 & 0 & 0 & 0 & 0 & 0 & 0 & 0 & 0 \\
\hline Chrysops & 0 & 0 & 0 & 0 & 0 & 0 & 0 & 0 & 0 & 0 & 0 & 0 & 0 \\
\hline Dolichopodidae(UNK) & 0 & 0 & 0 & 0 & 0 & 0 & 0 & 0 & 0 & 0 & 0 & 0 & 0 \\
\hline Simuliidae(UNK) & 0 & 4 & 0 & 0 & 0 & 0 & 0 & 0 & 2 & 3 & 8 & 6 & 0 \\
\hline Simulium & 0 & 0 & 0 & 0 & 0 & 0 & 0 & 0 & 0 & 0 & 0 & 0 & 0 \\
\hline Prosimulium & 0 & 0 & 0 & 0 & 0 & 0 & 0 & 0 & 0 & 0 & 0 & 0 & 0 \\
\hline Cnephia & 0 & 0 & 0 & 0 & 0 & 0 & 0 & 0 & 0 & 0 & 0 & 0 & 0 \\
\hline Greniera & 0 & 0 & 0 & 0 & 0 & 0 & 0 & 0 & 0 & 0 & 0 & 0 & 0 \\
\hline Atherix & 0 & 0 & 0 & 0 & 0 & 0 & 0 & 0 & 0 & 0 & 0 & 0 & 0 \\
\hline Empididae(UNK) & 0 & 0 & 0 & 0 & 0 & 0 & 0 & 0 & 0 & 0 & 0 & 0 & 0 \\
\hline Chelifera & 0 & 0 & 0 & 0 & 0 & 0 & 0 & 0 & 0 & 0 & 0 & 0 & 0 \\
\hline Clinocera & 0 & 0 & 0 & 0 & 0 & 0 & 0 & 0 & 0 & 0 & 0 & 0 & 1 \\
\hline Hemerodromia & 0 & 1 & 0 & 2 & 0 & 2 & 2 & 2 & 1 & 2 & 4 & 1 & 1 \\
\hline Wiedemannia & 0 & 0 & 0 & 0 & 0 & 0 & 0 & 0 & 0 & 0 & 0 & 0 & 0 \\
\hline Ceratopogonidae(UNK) & 0 & 10 & 0 & 7 & 0 & 0 & 0 & 0 & 0 & 1 & 1 & 0 & 0 \\
\hline Bezzia & 0 & 0 & 0 & 0 & 0 & 0 & 0 & 0 & 0 & 0 & 0 & 0 & 0 \\
\hline Dasyhelea & 0 & 0 & 0 & 0 & 0 & 0 & 0 & 0 & 0 & 0 & 0 & 0 & 0 \\
\hline Culicoides & 0 & 0 & 0 & 0 & 0 & 0 & 0 & 0 & 0 & 0 & 0 & 0 & 0 \\
\hline Atrichopogon & 0 & 0 & 0 & 0 & 0 & 0 & 0 & 0 & 0 & 0 & 0 & 0 & 0 \\
\hline Forcipomyia & 0 & 0 & 0 & 0 & 0 & 0 & 0 & 0 & 0 & 0 & 0 & 0 & 0 \\
\hline Probezzia & 0 & 0 & 0 & 0 & 0 & 0 & 0 & 0 & 0 & 0 & 0 & 0 & 0 \\
\hline Serromyia & 0 & 0 & 0 & 0 & 0 & 0 & 0 & 0 & 0 & 0 & 0 & 0 & 0 \\
\hline Monohelea & 0 & 0 & 0 & 0 & 0 & 0 & 0 & 0 & 0 & 0 & 0 & 0 & 0 \\
\hline Ceratopogon & 0 & 0 & 0 & 0 & 0 & 0 & 0 & 0 & 0 & 0 & 0 & 0 & 0 \\
\hline Blephariceridae(UNK) & 0 & 0 & 0 & 0 & 0 & 0 & 0 & 0 & 0 & 0 & 0 & 0 & 0 \\
\hline Blepharicera & 0 & 0 & 0 & 0 & 0 & 0 & 0 & 0 & 0 & 0 & 0 & 0 & 0 \\
\hline Sciomyzidae & 0 & 0 & 0 & 0 & 0 & 0 & 0 & 0 & 0 & 0 & 0 & 0 & 0 \\
\hline Dixa & 0 & 0 & 0 & 0 & 0 & 0 & 0 & 0 & 0 & 0 & 0 & 0 & 0 \\
\hline Stratiomyidae (UNK) & 0 & 0 & 0 & 0 & 0 & 0 & 0 & 0 & 0 & 0 & 0 & 0 & 0 \\
\hline Stratiomys & 0 & 0 & 0 & 0 & 0 & 0 & 0 & 0 & 0 & 0 & 0 & 0 & 0 \\
\hline Euparyphus & 0 & 0 & 0 & 0 & 0 & 0 & 0 & 0 & 0 & 0 & 0 & 0 & 0 \\
\hline Odontomyia & 0 & 0 & 0 & 0 & 0 & 0 & 0 & 0 & 0 & 0 & 0 & 0 & 0 \\
\hline
\end{tabular}




\begin{tabular}{|c|c|c|c|c|c|c|c|c|c|c|c|c|c|}
\hline Nemotelus & 0 & 0 & 0 & 0 & 0 & 0 & 0 & 0 & 0 & 0 & 0 & 0 & 0 \\
\hline Caloparyphus & 0 & 0 & 0 & 0 & 0 & 0 & 0 & 0 & 0 & 0 & 0 & 0 & 0 \\
\hline Protoplasa & 0 & 0 & 0 & 0 & 0 & 0 & 0 & 0 & 0 & 0 & 0 & 0 & 0 \\
\hline Muscidae(UNK) & 0 & 0 & 0 & 0 & 0 & 0 & 0 & 0 & 0 & 0 & 0 & 0 & 0 \\
\hline Limnophora & 0 & 0 & 0 & 0 & 0 & 0 & 0 & 0 & 0 & 0 & 0 & 0 & 0 \\
\hline Ephydridae(UNK) & 0 & 0 & 0 & 0 & 0 & 0 & 0 & 0 & 0 & 0 & 0 & 0 & 0 \\
\hline Parydra & 0 & 0 & 0 & 0 & 0 & 0 & 0 & 0 & 0 & 0 & 0 & 0 & 0 \\
\hline Thaumaleidae(UNK) & 0 & 0 & 0 & 0 & 0 & 0 & 0 & 0 & 0 & 0 & 0 & 0 & 0 \\
\hline Psychodidae(UNK) & 0 & 0 & 0 & 0 & 0 & 0 & 0 & 0 & 0 & 0 & 0 & 0 & 0 \\
\hline Pericoma & 0 & 0 & 0 & 0 & 0 & 0 & 0 & 0 & 0 & 0 & 0 & 0 & 0 \\
\hline Psychoda & 0 & 0 & 0 & 0 & 0 & 0 & 0 & 0 & 0 & 0 & 0 & 0 & 0 \\
\hline Anopheles & 0 & 0 & 0 & 0 & 0 & 0 & 0 & 0 & 0 & 0 & 0 & 0 & 0 \\
\hline Unknown Diptera & 0 & 0 & 0 & 1 & 0 & 0 & 0 & 0 & 0 & 0 & 0 & 0 & 0 \\
\hline Hydracarina & 0 & 0 & 0 & 0 & 0 & 0 & 0 & 0 & 0 & 0 & 0 & 0 & 0 \\
\hline Hygrobatoidea & 0 & 0 & 0 & 0 & 0 & 0 & 0 & 0 & 0 & 0 & 0 & 0 & 0 \\
\hline Pisauridae & 0 & 0 & 0 & 0 & 0 & 0 & 0 & 0 & 0 & 0 & 0 & 0 & 0 \\
\hline Lycosidae & 0 & 0 & 0 & 0 & 0 & 0 & 0 & 0 & 0 & 0 & 0 & 0 & 0 \\
\hline Collembola (UNK) & 0 & 1 & 0 & 0 & 0 & 0 & 0 & 0 & 0 & 0 & 1 & 0 & 0 \\
\hline Sminthuridae(UNK) & 0 & 0 & 0 & 0 & 0 & 0 & 0 & 0 & 0 & 0 & 0 & 0 & 0 \\
\hline Bourletiella & 0 & 0 & 0 & 0 & 0 & 0 & 0 & 0 & 0 & 0 & 0 & 0 & 0 \\
\hline Sminthurides & 0 & 0 & 0 & 0 & 0 & 0 & 0 & 0 & 0 & 0 & 0 & 0 & 0 \\
\hline Agrenia bidenticulata & 0 & 0 & 0 & 0 & 0 & 0 & 0 & 0 & 0 & 0 & 0 & 0 & 0 \\
\hline Hydroisotoma & 0 & 0 & 0 & 0 & 0 & 0 & 0 & 0 & 0 & 0 & 0 & 0 & 0 \\
\hline Isotomorus & 0 & 0 & 0 & 0 & 0 & 0 & 0 & 0 & 0 & 0 & 0 & 0 & 0 \\
\hline Isotomidae(UNK) & 0 & 0 & 0 & 0 & 0 & 0 & 0 & 0 & 0 & 0 & 0 & 0 & 0 \\
\hline Neanuridae & 0 & 0 & 0 & 0 & 0 & 0 & 0 & 0 & 0 & 0 & 0 & 0 & 0 \\
\hline Podura & 0 & 0 & 0 & 0 & 0 & 0 & 0 & 0 & 0 & 0 & 0 & 0 & 0 \\
\hline Poduridae(UNK) & 0 & 0 & 0 & 0 & 0 & 0 & 0 & 0 & 0 & 0 & 0 & 0 & 0 \\
\hline UNK (Copepoda) & 0 & 0 & 0 & 0 & 0 & 0 & 0 & 0 & 0 & 0 & 0 & 0 & 0 \\
\hline Cyclopoida & 0 & 0 & 0 & 0 & 0 & 0 & 0 & 0 & 0 & 0 & 0 & 0 & 0 \\
\hline Daphnia & 0 & 0 & 0 & 0 & 0 & 0 & 0 & 0 & 0 & 0 & 0 & 0 & 0 \\
\hline
\end{tabular}

Appendix 7. Benthic macroinvertebrate data for Three Forks Creek by sample location in 2017. With the exception of Chironomidae, macroinvertebrates were identified to genus if possible. UNK=unknown. 


\begin{tabular}{|c|c|c|c|c|c|c|c|c|c|c|c|c|c|c|c|c|c|c|c|c|}
\hline Site & 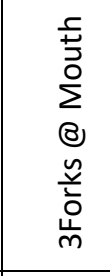 & 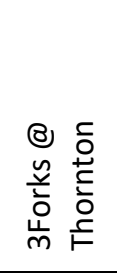 & 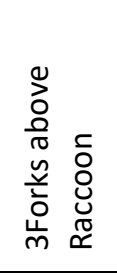 & 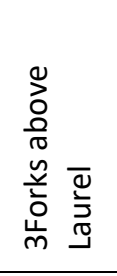 & 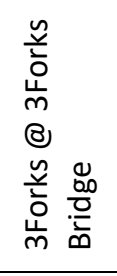 & 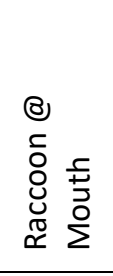 & $\begin{array}{l}\stackrel{\tilde{u}}{\tilde{J}} \\
\stackrel{\tilde{n}}{ }\end{array}$ & 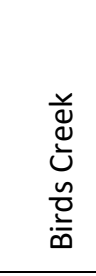 & 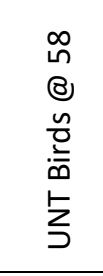 & 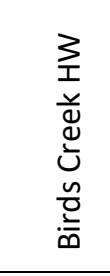 & 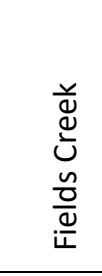 & 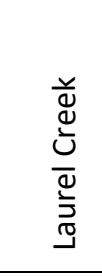 & 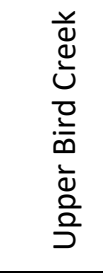 & 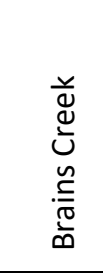 & 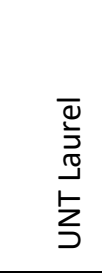 & $\begin{array}{l}\text { Dे } \\
\text { Oे }\end{array}$ & 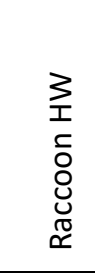 & 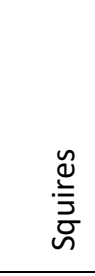 & 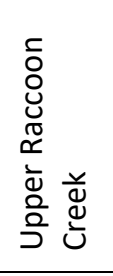 & $\frac{\tilde{v}}{0}$ \\
\hline Year & 2017 & 2017 & 2017 & 2017 & 2017 & 2017 & 2017 & 2017 & 2017 & 2017 & 2017 & 2017 & 2017 & 2017 & 2017 & 2017 & 2017 & 2017 & 2017 & 2017 \\
\hline Turbellaria & 0 & 0 & 0 & 0 & 0 & 0 & 0 & 0 & 0 & 0 & 0 & 0 & 0 & 0 & 0 & 0 & 0 & 0 & 0 & 0 \\
\hline Oligochaeta & 0 & 0 & 0 & 0 & 0 & 0 & 0 & 0 & 0 & 0 & 0 & 0 & 0 & 0 & 0 & 0 & 0 & 0 & 0 & 0 \\
\hline Aeolosomatidae & 0 & 0 & 0 & 0 & 0 & 0 & 0 & 0 & 0 & 0 & 0 & 0 & 0 & 0 & 0 & 0 & 0 & 0 & 0 & 0 \\
\hline Nematoda & 0 & 0 & 0 & 0 & 0 & 0 & 0 & 0 & 0 & 0 & 0 & 0 & 0 & 0 & 0 & 0 & 0 & 0 & 0 & 0 \\
\hline Nemertea & 0 & 0 & 0 & 0 & 0 & 0 & 0 & 0 & 0 & 0 & 0 & 0 & 0 & 0 & 0 & 0 & 0 & 0 & 0 & 0 \\
\hline Hirudinea & 0 & 0 & 0 & 0 & 0 & 0 & 0 & 0 & 0 & 0 & 0 & 0 & 0 & 0 & 0 & 0 & 0 & 0 & 0 & 0 \\
\hline Corbiculidae & 0 & 0 & 0 & 0 & 0 & 0 & 0 & 0 & 0 & 0 & 0 & 0 & 0 & 0 & 0 & 0 & 0 & 0 & 0 & 0 \\
\hline Sphaeriidae & 0 & 0 & 0 & 0 & 0 & 0 & 0 & 0 & 0 & 0 & 0 & 0 & 0 & 0 & 0 & 0 & 0 & 0 & 0 & 0 \\
\hline Unionidae & 0 & 0 & 0 & 0 & 0 & 0 & 0 & 0 & 0 & 0 & 0 & 0 & 0 & 0 & 0 & 0 & 0 & 0 & 0 & 0 \\
\hline Clams & 0 & 0 & 0 & 0 & 0 & 0 & 0 & 0 & 0 & 0 & 0 & 0 & 0 & 0 & 0 & 0 & 0 & 0 & 0 & 0 \\
\hline Ancylidae & 0 & 0 & 0 & 0 & 0 & 0 & 0 & 0 & 0 & 0 & 0 & 0 & 0 & 0 & 0 & 0 & 0 & 0 & 0 & 0 \\
\hline Planorbidae & 0 & 0 & 0 & 0 & 0 & 0 & 0 & 0 & 0 & 0 & 0 & 0 & 0 & 0 & 0 & 0 & 0 & 0 & 0 & 0 \\
\hline Physidae & 0 & 0 & 0 & 0 & 0 & 0 & 0 & 0 & 0 & 0 & 0 & 0 & 0 & 0 & 0 & 0 & 0 & 0 & 0 & 0 \\
\hline Lymnaeidae & 0 & 0 & 0 & 0 & 0 & 0 & 0 & 0 & 0 & 0 & 0 & 0 & 0 & 0 & 0 & 0 & 0 & 0 & 0 & 0 \\
\hline Snails(UNK) & 0 & 0 & 0 & 0 & 0 & 0 & 0 & 0 & 0 & 0 & 0 & 0 & 0 & 0 & 0 & 0 & 0 & 0 & 0 & 0 \\
\hline Cambarus & 0 & 0 & 0 & 0 & 0 & 0 & 0 & 0 & 0 & 0 & 0 & 0 & 0 & 0 & 0 & 0 & 0 & 0 & 0 & 0 \\
\hline Orconectes & 0 & 0 & 0 & 0 & 0 & 0 & 0 & 0 & 0 & 0 & 0 & 0 & 0 & 0 & 0 & 0 & 0 & 0 & 0 & 0 \\
\hline Gammarus & 0 & 0 & 0 & 0 & 0 & 0 & 0 & 0 & 0 & 0 & 0 & 0 & 0 & 0 & 0 & 0 & 0 & 0 & 0 & 0 \\
\hline Hyalella & 0 & 0 & 0 & 0 & 0 & 0 & 0 & 0 & 0 & 0 & 0 & 0 & 0 & 0 & 0 & 0 & 0 & 0 & 0 & 0 \\
\hline Crangonyx & 0 & 0 & 0 & 0 & 0 & 0 & 0 & 0 & 0 & 0 & 0 & 0 & 0 & 0 & 0 & 0 & 0 & 0 & 0 & 0 \\
\hline Stygobromus & 0 & 0 & 0 & 0 & 0 & 0 & 0 & 0 & 0 & 0 & 0 & 0 & 0 & 0 & 0 & 0 & 0 & 0 & 0 & 0 \\
\hline Asellidae(UNK) & 0 & 0 & 0 & 0 & 0 & 0 & 0 & 0 & 0 & 0 & 0 & 0 & 0 & 0 & 0 & 0 & 0 & 0 & 0 & 0 \\
\hline Caecidotea & 0 & 0 & 0 & 0 & 0 & 0 & 0 & 0 & 0 & 0 & 0 & 0 & 0 & 0 & 0 & 0 & 0 & 0 & 0 & 0 \\
\hline Lirceus & 0 & 0 & 0 & 0 & 0 & 0 & 0 & 0 & 0 & 0 & 0 & 0 & 0 & 0 & 0 & 0 & 0 & 0 & 0 & 0 \\
\hline Baetidae(UNK) & 0 & 0 & 0 & 0 & 0 & 0 & 0 & 0 & 0 & 0 & 0 & 0 & 0 & 0 & 0 & 0 & 0 & 0 & 0 & 0 \\
\hline Accentrella & 20 & 37 & 49 & 3 & 1 & 35 & 2 & 0 & 0 & 0 & 7 & 12 & 1 & 16 & 9 & 26 & 0 & 0 & 2 & 17 \\
\hline
\end{tabular}




\begin{tabular}{|c|c|c|c|c|c|c|c|c|c|c|c|c|c|c|c|c|c|c|c|c|}
\hline Baetis & 38 & 41 & 21 & 10 & 0 & 10 & 38 & 2 & 0 & 0 & 19 & 11 & 0 & 6 & 47 & 6 & 0 & 1 & 3 & 36 \\
\hline Plauditus & 21 & 14 & 27 & 2 & 3 & 12 & 1 & 0 & 0 & 0 & 9 & 26 & 0 & 9 & 4 & 25 & 0 & 0 & 0 & 4 \\
\hline Procloeon & 0 & 0 & 0 & 0 & 0 & 0 & 0 & 0 & 0 & 0 & 0 & 0 & 0 & 0 & 0 & 0 & 0 & 0 & 0 & 0 \\
\hline Acerpenna & 0 & 0 & 0 & 0 & 0 & 0 & 0 & 0 & 0 & 0 & 0 & 0 & 0 & 0 & 0 & 0 & 0 & 0 & 0 & 0 \\
\hline Diphetor & 0 & 0 & 0 & 0 & 0 & 0 & 0 & 0 & 0 & 0 & 0 & 0 & 0 & 0 & 0 & 0 & 0 & 0 & 0 & 0 \\
\hline Heterocloeon & 1 & 0 & 0 & 0 & 0 & 0 & 0 & 0 & 0 & 0 & 0 & 0 & 0 & 2 & 1 & 0 & 0 & 0 & 0 & 0 \\
\hline Centroptilum & 0 & 0 & 0 & 0 & 0 & 0 & 0 & 0 & 0 & 0 & 0 & 0 & 0 & 0 & 0 & 0 & 0 & 0 & 0 & 1 \\
\hline Caenis & 0 & 0 & 0 & 0 & 0 & 0 & 0 & 0 & 0 & 0 & 0 & 0 & 0 & 0 & 0 & 0 & 0 & 0 & 0 & 0 \\
\hline Heptageniidae(UNK) & 0 & 0 & 0 & 0 & 0 & 0 & 0 & 0 & 0 & 0 & 0 & 0 & 0 & 0 & 0 & 0 & 0 & 0 & 0 & 0 \\
\hline Epeorus & 0 & 1 & 0 & 0 & 0 & 0 & 0 & 0 & 0 & 0 & 1 & 0 & 0 & 0 & 0 & 0 & 0 & 0 & 0 & 6 \\
\hline Heptagenia & 0 & 0 & 0 & 0 & 0 & 0 & 0 & 0 & 0 & 0 & 0 & 0 & 0 & 0 & 0 & 0 & 0 & 0 & 0 & 0 \\
\hline Stenonema/Maccaffertium & 0 & 0 & 1 & 0 & 0 & 0 & 0 & 0 & 0 & 0 & 2 & 1 & 0 & 0 & 0 & 8 & 0 & 0 & 0 & 2 \\
\hline Cinygmula & 0 & 0 & 0 & 0 & 0 & 0 & 0 & 0 & 0 & 0 & 0 & 0 & 0 & 0 & 0 & 0 & 0 & 0 & 0 & 0 \\
\hline Stenacron & 0 & 0 & 0 & 0 & 0 & 0 & 4 & 0 & 0 & 0 & 0 & 0 & 0 & 2 & 3 & 5 & 0 & 0 & 0 & 3 \\
\hline Leucrocuta & 0 & 0 & 0 & 0 & 0 & 0 & 0 & 0 & 0 & 0 & 0 & 0 & 0 & 0 & 0 & 0 & 0 & 0 & 0 & 0 \\
\hline Isonychia & 0 & 0 & 0 & 0 & 0 & 0 & 0 & 0 & 0 & 0 & 0 & 0 & 0 & 0 & 0 & 0 & 0 & 0 & 0 & 0 \\
\hline Leptophelbiidae(UNK) & 0 & 0 & 0 & 0 & 0 & 0 & 0 & 0 & 0 & 0 & 0 & 0 & 0 & 0 & 0 & 0 & 0 & 0 & 0 & 0 \\
\hline Paraleptophlebia & 0 & 0 & 0 & 0 & 0 & 0 & 3 & 1 & 0 & 0 & 12 & 2 & 0 & 0 & 2 & 0 & 0 & 0 & 2 & 5 \\
\hline Leptophlebia & 0 & 0 & 0 & 0 & 0 & 0 & 0 & 0 & 0 & 0 & 0 & 0 & 0 & 0 & 0 & 0 & 0 & 0 & 0 & 0 \\
\hline Habrophlebiodes & 0 & 0 & 0 & 0 & 0 & 0 & 0 & 0 & 0 & 0 & 0 & 0 & 0 & 0 & 0 & 0 & 0 & 0 & 0 & 0 \\
\hline Ephemerellidae(UNK) & 0 & 0 & 0 & 0 & 0 & 0 & 0 & 0 & 0 & 0 & 0 & 0 & 0 & 0 & 0 & 0 & 0 & 0 & 0 & 0 \\
\hline Ephemerella & 1 & 0 & 1 & 0 & 0 & 0 & 0 & 0 & 0 & 0 & 1 & 4 & 0 & 0 & 6 & 1 & 0 & 0 & 0 & 8 \\
\hline Serratella & 0 & 0 & 0 & 0 & 0 & 0 & 0 & 0 & 0 & 0 & 0 & 0 & 0 & 0 & 0 & 0 & 0 & 0 & 0 & 0 \\
\hline Drunella & 0 & 0 & 0 & 0 & 0 & 0 & 2 & 0 & 0 & 0 & 3 & 1 & 0 & 0 & 7 & 0 & 0 & 0 & 0 & 0 \\
\hline Dannella & 0 & 0 & 0 & 0 & 0 & 0 & 0 & 0 & 0 & 0 & 0 & 0 & 0 & 0 & 0 & 0 & 0 & 0 & 0 & 0 \\
\hline Eurylophella & 0 & 0 & 0 & 0 & 0 & 0 & 0 & 0 & 0 & 0 & 0 & 0 & 0 & 0 & 0 & 1 & 0 & 0 & 0 & 0 \\
\hline Attenella & 0 & 0 & 0 & 0 & 0 & 0 & 0 & 0 & 0 & 0 & 0 & 0 & 0 & 0 & 0 & 0 & 0 & 0 & 0 & 0 \\
\hline Siphlonuridae & 0 & 0 & 0 & 0 & 0 & 0 & 0 & 0 & 0 & 0 & 0 & 0 & 0 & 0 & 0 & 0 & 0 & 0 & 0 & 0 \\
\hline Tricorythodes & 0 & 0 & 0 & 0 & 0 & 0 & 0 & 0 & 0 & 0 & 0 & 0 & 0 & 0 & 0 & 0 & 0 & 0 & 0 & 0 \\
\hline Ephemera & 0 & 0 & 0 & 0 & 0 & 0 & 0 & 0 & 0 & 0 & 0 & 0 & 0 & 0 & 0 & 0 & 0 & 0 & 0 & 0 \\
\hline Hexagenia & 0 & 0 & 0 & 0 & 0 & 0 & 0 & 0 & 0 & 0 & 0 & 0 & 0 & 0 & 0 & 0 & 0 & 0 & 0 & 0 \\
\hline Ameletus & 0 & 0 & 0 & 0 & 0 & 0 & 0 & 0 & 0 & 0 & 0 & 0 & 0 & 0 & 0 & 0 & 0 & 1 & 0 & 0 \\
\hline Neoephemeridae & 0 & 0 & 0 & 0 & 0 & 0 & 0 & 0 & 0 & 0 & 0 & 0 & 0 & 0 & 0 & 0 & 0 & 0 & $\begin{array}{c}0 \\
10\end{array}$ & 0 \\
\hline
\end{tabular}




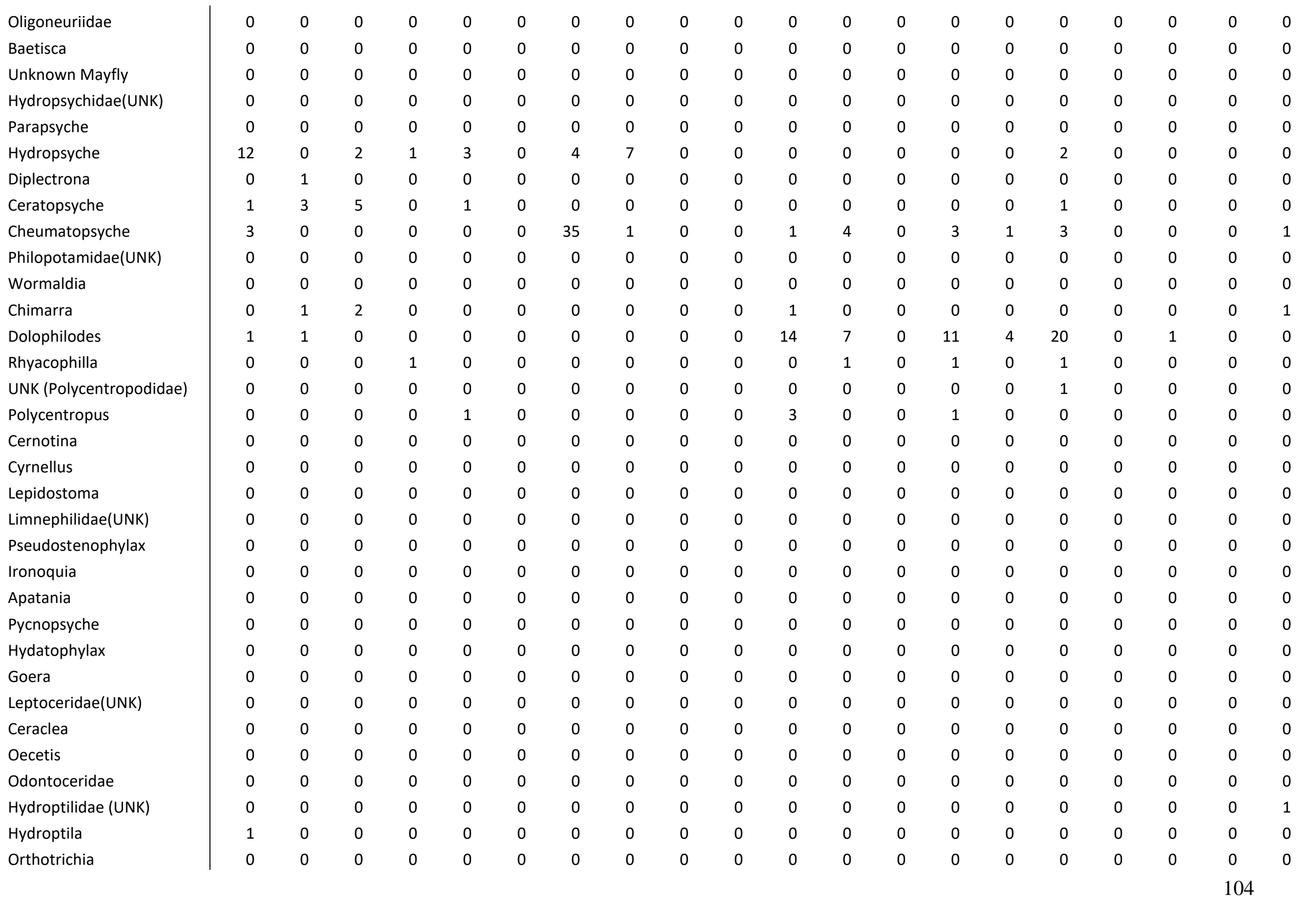




\begin{tabular}{|c|c|c|c|c|c|c|c|c|c|c|c|c|c|c|c|c|c|c|c|c|}
\hline Ochrotrichia & 0 & 0 & 0 & 0 & 0 & 0 & 0 & 0 & 0 & 0 & 0 & 0 & 0 & 0 & 0 & 0 & 0 & 0 & 0 & 0 \\
\hline Palaeagapetus & 0 & 0 & 0 & 0 & 0 & 0 & 0 & 0 & 0 & 0 & 0 & 0 & 0 & 0 & 0 & 0 & 0 & 0 & 0 & 0 \\
\hline Stactobiella & 0 & 0 & 0 & 0 & 0 & 0 & 0 & 0 & 0 & 0 & 0 & 0 & 0 & 0 & 0 & 0 & 0 & 0 & 0 & 1 \\
\hline Leucotrichia & 0 & 0 & 0 & 0 & 0 & 0 & 0 & 0 & 0 & 0 & 0 & 0 & 0 & 0 & 0 & 0 & 0 & 0 & 0 & 0 \\
\hline Oxyethira & 0 & 0 & 0 & 0 & 0 & 0 & 0 & 0 & 0 & 0 & 0 & 0 & 0 & 0 & 0 & 0 & 0 & 0 & 0 & 0 \\
\hline Agapetus & 0 & 0 & 0 & 0 & 0 & 0 & 0 & 0 & 0 & 0 & 0 & 1 & 0 & 0 & 0 & 0 & 0 & 0 & 0 & 0 \\
\hline Glossosoma & 0 & 0 & 0 & 0 & 0 & 0 & 0 & 0 & 0 & 0 & 1 & 0 & 0 & 0 & 0 & 0 & 0 & 0 & 0 & 0 \\
\hline Brachycentrus & 0 & 0 & 0 & 0 & 0 & 0 & 0 & 0 & 0 & 0 & 0 & 0 & 0 & 0 & 0 & 0 & 0 & 0 & 0 & 0 \\
\hline Helicopsychidae & 0 & 0 & 0 & 0 & 0 & 0 & 0 & 0 & 0 & 0 & 0 & 0 & 0 & 0 & 0 & 0 & 0 & 0 & 0 & 0 \\
\hline Lype & 0 & 0 & 0 & 0 & 0 & 0 & 0 & 0 & 0 & 0 & 0 & 0 & 0 & 0 & 0 & 0 & 0 & 0 & 0 & 0 \\
\hline Psychomyia & 0 & 0 & 0 & 0 & 0 & 0 & 0 & 0 & 0 & 0 & 0 & 0 & 0 & 0 & 0 & 0 & 0 & 0 & 0 & 0 \\
\hline Neophylax & 0 & 0 & 0 & 0 & 0 & 0 & 0 & 0 & 0 & 0 & 0 & 0 & 0 & 0 & 0 & 0 & 0 & 0 & 0 & 0 \\
\hline Molanna & 0 & 0 & 0 & 0 & 0 & 0 & 0 & 0 & 0 & 0 & 0 & 0 & 0 & 0 & 0 & 0 & 0 & 0 & 0 & 0 \\
\hline Phryganeidae(UNK) & 0 & 0 & 0 & 0 & 0 & 0 & 0 & 0 & 0 & 0 & 0 & 0 & 0 & 0 & 0 & 0 & 0 & 0 & 0 & 0 \\
\hline Unkown Caddisfly & 0 & 0 & 0 & 0 & 0 & 0 & 0 & 0 & 0 & 0 & 0 & 0 & 0 & 0 & 0 & 0 & 0 & 0 & 0 & 0 \\
\hline Chloroperlidae(UNK) & 0 & 0 & 0 & 0 & 0 & 0 & 0 & 0 & 0 & 0 & 0 & 0 & 0 & 0 & 0 & 0 & 0 & 0 & 0 & 0 \\
\hline Haploperla & 0 & 0 & 0 & 0 & 0 & 0 & 0 & 0 & 0 & 0 & 0 & 0 & 0 & 0 & 0 & 1 & 0 & 0 & 0 & 1 \\
\hline Utaperla & 0 & 0 & 0 & 0 & 0 & 0 & 0 & 0 & 0 & 0 & 0 & 0 & 0 & 0 & 0 & 0 & 0 & 0 & 0 & 0 \\
\hline Sweltsa & 0 & 0 & 0 & 0 & 0 & 0 & 0 & 0 & 0 & 0 & 0 & 0 & 0 & 0 & 0 & 0 & 0 & 0 & 0 & 0 \\
\hline Suwallia & 0 & 0 & 0 & 0 & 0 & 0 & 0 & 0 & 0 & 0 & 0 & 0 & 0 & 0 & 0 & 0 & 0 & 0 & 0 & 0 \\
\hline Alloperla & 0 & 0 & 0 & 0 & 1 & 1 & 0 & 0 & 0 & 0 & 0 & 0 & 0 & 0 & 0 & 0 & 0 & 0 & 0 & 0 \\
\hline Capniidae(UNK) & 0 & 0 & 0 & 0 & 0 & 0 & 0 & 0 & 0 & 0 & 0 & 0 & 0 & 0 & 0 & 0 & 0 & 0 & 0 & 0 \\
\hline Paracapnia & 0 & 0 & 0 & 0 & 0 & 0 & 0 & 0 & 0 & 0 & 0 & 0 & 0 & 0 & 0 & 0 & 0 & 0 & 0 & 0 \\
\hline Capnia & 0 & 0 & 0 & 0 & 0 & 0 & 0 & 0 & 0 & 0 & 0 & 0 & 0 & 0 & 0 & 0 & 0 & 0 & 0 & 0 \\
\hline Allocapnia & 0 & 0 & 0 & 0 & 0 & 0 & 0 & 0 & 0 & 0 & 0 & 0 & 0 & 0 & 0 & 0 & 0 & 0 & 0 & 0 \\
\hline Leuctridae(UNK) & 0 & 0 & 0 & 0 & 0 & 0 & 0 & 0 & 0 & 0 & 0 & 0 & 0 & 0 & 0 & 0 & 0 & 0 & 0 & 0 \\
\hline Paraleuctra & 0 & 0 & 0 & 0 & 0 & 0 & 0 & 0 & 0 & 0 & 0 & 0 & 0 & 0 & 0 & 0 & 0 & 0 & 0 & 0 \\
\hline Leuctra & 4 & 3 & 0 & 2 & 0 & 10 & 5 & 5 & 12 & 163 & 10 & 11 & 36 & 47 & 11 & 5 & 1 & 1 & 7 & 17 \\
\hline Zealeuctra & 0 & 0 & 0 & 0 & 0 & 0 & 0 & 0 & 0 & 0 & 0 & 0 & 0 & 0 & 0 & 0 & 0 & 0 & 0 & 0 \\
\hline Perlidae(UNK) & 0 & 0 & 0 & 0 & 0 & 0 & 0 & 0 & 0 & 0 & 0 & 0 & 0 & 0 & 0 & 0 & 0 & 0 & 0 & 0 \\
\hline Acroneuria & 0 & 0 & 2 & 1 & 2 & 0 & 0 & 0 & 0 & 0 & 1 & 1 & 0 & 1 & 1 & 1 & 0 & 0 & 0 & 0 \\
\hline Agnetina & 0 & 0 & 0 & 0 & 0 & 0 & 0 & 0 & 0 & 0 & 0 & 0 & 0 & 0 & 0 & 0 & 0 & 0 & 0 & 0 \\
\hline Eccoptura & 0 & 0 & 0 & 0 & 0 & 0 & 1 & 0 & 0 & 0 & 0 & 0 & 0 & 0 & 0 & 0 & 0 & 0 & 0 & 0 \\
\hline
\end{tabular}




\begin{tabular}{|c|c|c|c|c|c|c|c|c|c|c|c|c|c|c|c|c|c|c|c|c|}
\hline Beloneuria & 0 & 0 & 0 & 0 & 0 & 0 & 0 & 0 & 0 & 0 & 0 & 0 & 0 & 0 & 0 & 0 & 0 & 0 & 0 & 0 \\
\hline Hansonoperla & 0 & 0 & 0 & 0 & 0 & 0 & 0 & 0 & 0 & 0 & 0 & 0 & 0 & 0 & 0 & 0 & 0 & 0 & 0 & 0 \\
\hline Claassenia & 0 & 0 & 0 & 0 & 0 & 0 & 0 & 0 & 0 & 0 & 0 & 0 & 0 & 0 & 0 & 0 & 0 & 0 & 0 & 0 \\
\hline Neoperla & 0 & 1 & 0 & 0 & 0 & 0 & 0 & 0 & 0 & 0 & 0 & 0 & 0 & 0 & 0 & 0 & 0 & 0 & 0 & 0 \\
\hline Paragnetina & 0 & 0 & 0 & 0 & 0 & 0 & 0 & 0 & 0 & 0 & 0 & 0 & 0 & 0 & 0 & 0 & 0 & 0 & 0 & 0 \\
\hline Attaneuria & 0 & 0 & 0 & 0 & 0 & 0 & 0 & 0 & 0 & 0 & 0 & 0 & 0 & 0 & 0 & 0 & 0 & 0 & 0 & 0 \\
\hline Perlesta & 0 & 0 & 0 & 0 & 0 & 0 & 0 & 0 & 0 & 0 & 0 & 0 & 0 & 0 & 0 & 0 & 0 & 0 & 0 & 0 \\
\hline Pteronarcys & 0 & 0 & 0 & 0 & 0 & 0 & 0 & 0 & 0 & 0 & 0 & 0 & 0 & 0 & 0 & 0 & 0 & 0 & 0 & 0 \\
\hline Perlodidae(UNK) & 0 & 0 & 0 & 0 & 0 & 0 & 0 & 0 & 0 & 0 & 0 & 0 & 0 & 0 & 0 & 0 & 0 & 0 & 0 & 1 \\
\hline Isoperla & 3 & 0 & 0 & 0 & 0 & 1 & 0 & 0 & 0 & 0 & 0 & 1 & 0 & 10 & 1 & 0 & 0 & 0 & 1 & 0 \\
\hline Diura & 0 & 0 & 0 & 0 & 0 & 0 & 0 & 0 & 0 & 0 & 0 & 0 & 0 & 0 & 0 & 0 & 0 & 0 & 0 & 0 \\
\hline Cultus & 0 & 0 & 0 & 0 & 0 & 0 & 0 & 0 & 0 & 0 & 0 & 0 & 0 & 0 & 0 & 0 & 0 & 0 & 0 & 0 \\
\hline Remenus & 0 & 0 & 0 & 0 & 0 & 0 & 0 & 0 & 0 & 0 & 0 & 0 & 0 & 0 & 0 & 0 & 0 & 0 & 0 & 0 \\
\hline Malirekus & 0 & 0 & 0 & 0 & 0 & 0 & 0 & 0 & 0 & 0 & 0 & 0 & 0 & 0 & 0 & 0 & 0 & 0 & 0 & 0 \\
\hline Diploperla & 0 & 0 & 0 & 0 & 0 & 0 & 0 & 0 & 0 & 0 & 0 & 0 & 0 & 0 & 0 & 0 & 0 & 0 & 0 & 0 \\
\hline Yugus & 0 & 0 & 0 & 0 & 0 & 0 & 0 & 0 & 0 & 0 & 0 & 0 & 0 & 0 & 0 & 0 & 0 & 0 & 0 & 0 \\
\hline Tallaperla & 0 & 0 & 0 & 1 & 0 & 0 & 0 & 0 & 1 & 0 & 0 & 0 & 0 & 0 & 0 & 0 & 0 & 0 & 0 & 0 \\
\hline Peltoperla & 0 & 0 & 0 & 0 & 0 & 0 & 0 & 0 & 0 & 0 & 0 & 0 & 0 & 0 & 0 & 0 & 0 & 0 & 0 & 0 \\
\hline Viehoperla & 0 & 0 & 0 & 0 & 0 & 0 & 0 & 0 & 0 & 0 & 0 & 0 & 0 & 0 & 0 & 0 & 0 & 0 & 0 & 0 \\
\hline Soyedina & 0 & 0 & 0 & 0 & 0 & 0 & 0 & 0 & 0 & 0 & 0 & 0 & 0 & 0 & 0 & 0 & 0 & 0 & 0 & 0 \\
\hline Amphinemuera & 0 & 1 & 0 & 3 & 0 & 3 & 0 & 3 & 2 & 0 & 0 & 0 & 0 & 0 & 2 & 0 & 0 & 0 & 4 & 1 \\
\hline Ostrocerca & 0 & 0 & 0 & 0 & 0 & 0 & 0 & 0 & 0 & 0 & 0 & 0 & 0 & 0 & 0 & 0 & 0 & 0 & 0 & 0 \\
\hline Zapada & 0 & 0 & 0 & 0 & 0 & 0 & 0 & 0 & 0 & 0 & 0 & 0 & 0 & 0 & 0 & 0 & 0 & 0 & 0 & 0 \\
\hline Paranemoura & 0 & 0 & 0 & 0 & 0 & 0 & 0 & 0 & 0 & 0 & 0 & 0 & 0 & 0 & 0 & 0 & 0 & 0 & 0 & 0 \\
\hline Shipsa & 0 & 0 & 0 & 0 & 0 & 0 & 0 & 0 & 0 & 0 & 0 & 0 & 0 & 0 & 0 & 0 & 0 & 0 & 0 & 0 \\
\hline Taeniopteryx & 0 & 0 & 0 & 0 & 0 & 0 & 0 & 0 & 0 & 0 & 0 & 0 & 0 & 0 & 0 & 0 & 0 & 0 & 0 & 0 \\
\hline Taeniopterygidae(UNK) & 0 & 0 & 0 & 0 & 0 & 0 & 0 & 0 & 0 & 0 & 0 & 0 & 0 & 0 & 0 & 0 & 0 & 0 & 0 & 0 \\
\hline Unknown Stonefly & 0 & 0 & 0 & 0 & 0 & 0 & 0 & 0 & 0 & 0 & 0 & 0 & 0 & 0 & 2 & 0 & 0 & 0 & 0 & 0 \\
\hline Gomphidae(UNK) & 0 & 0 & 0 & 0 & 0 & 0 & 0 & 0 & 0 & 0 & 0 & 0 & 0 & 0 & 0 & 0 & 0 & 0 & 0 & 0 \\
\hline Gomphus & 0 & 0 & 0 & 0 & 0 & 0 & 0 & 0 & 0 & 0 & 0 & 0 & 0 & 0 & 0 & 0 & 0 & 0 & 0 & 0 \\
\hline Lanthus & 0 & 0 & 0 & 0 & 0 & 0 & 0 & 0 & 0 & 0 & 0 & 0 & 0 & 0 & 0 & 0 & 0 & 0 & 0 & 0 \\
\hline Progomphus & 0 & 0 & 0 & 0 & 0 & 0 & 0 & 0 & 0 & 0 & 0 & 0 & 0 & 0 & 0 & 0 & 0 & 0 & 0 & 0 \\
\hline Stylogomphus & 0 & 0 & 0 & 0 & 0 & 0 & 0 & 0 & 0 & 0 & 0 & 0 & 0 & 0 & 0 & 0 & 0 & 0 & 0 & 0 \\
\hline
\end{tabular}




\begin{tabular}{|c|c|c|c|c|c|c|c|c|c|c|c|c|c|c|c|c|c|c|c|c|}
\hline Dromogomphus & 0 & 0 & 0 & 0 & 0 & 0 & 0 & 0 & 0 & 0 & 0 & 0 & 0 & 0 & 0 & 0 & 0 & 0 & 0 & 0 \\
\hline Arigomphus & 0 & 0 & 0 & 0 & 0 & 0 & 0 & 0 & 0 & 0 & 0 & 0 & 0 & 0 & 0 & 0 & 0 & 0 & 0 & 0 \\
\hline Cordulegaster & 0 & 0 & 0 & 0 & 0 & 0 & 0 & 0 & 0 & 0 & 0 & 0 & 0 & 0 & 0 & 0 & 0 & 0 & 0 & 0 \\
\hline Aeshnidae (UNK) & 1 & 0 & 0 & 0 & 0 & 0 & 0 & 0 & 0 & 0 & 0 & 0 & 0 & 0 & 0 & 0 & 0 & 0 & 0 & 0 \\
\hline Aeshna & 0 & 0 & 0 & 0 & 0 & 0 & 0 & 0 & 0 & 0 & 0 & 0 & 0 & 0 & 0 & 0 & 0 & 0 & 0 & 0 \\
\hline Boyeria & 0 & 0 & 0 & 0 & 0 & 0 & 0 & 0 & 0 & 0 & 0 & 1 & 0 & 0 & 0 & 0 & 0 & 0 & 0 & 0 \\
\hline Epiaeschna & 0 & 0 & 0 & 0 & 0 & 0 & 0 & 0 & 0 & 0 & 0 & 0 & 0 & 0 & 0 & 0 & 0 & 0 & 0 & 0 \\
\hline Calopteryx & 0 & 0 & 0 & 0 & 0 & 0 & 0 & 0 & 0 & 0 & 0 & 0 & 0 & 0 & 0 & 0 & 0 & 0 & 0 & 0 \\
\hline Calopterygidae(UNK) & 0 & 0 & 0 & 0 & 0 & 0 & 0 & 0 & 0 & 0 & 0 & 0 & 0 & 0 & 0 & 0 & 0 & 0 & 0 & 0 \\
\hline Libellulidae & 0 & 0 & 0 & 0 & 0 & 0 & 0 & 0 & 0 & 0 & 0 & 0 & 0 & 0 & 0 & 0 & 0 & 0 & 0 & 0 \\
\hline Cornagrion & 0 & 0 & 0 & 0 & 0 & 0 & 0 & 0 & 0 & 0 & 0 & 0 & 0 & 0 & 0 & 0 & 0 & 0 & 0 & 0 \\
\hline Argia & 0 & 0 & 0 & 0 & 0 & 0 & 0 & 0 & 0 & 0 & 0 & 0 & 0 & 0 & 0 & 0 & 0 & 0 & 0 & 0 \\
\hline Coenagrionidae(UNK) & 0 & 0 & 0 & 0 & 0 & 0 & 0 & 0 & 0 & 0 & 0 & 0 & 0 & 0 & 0 & 0 & 0 & 0 & 0 & 0 \\
\hline Lestes & 0 & 0 & 0 & 0 & 0 & 0 & 0 & 0 & 0 & 0 & 0 & 0 & 0 & 0 & 0 & 0 & 0 & 0 & 0 & 0 \\
\hline Unkown Dragonfly & 0 & 0 & 0 & 1 & 0 & 0 & 0 & 0 & 0 & 0 & 0 & 0 & 0 & 0 & 0 & 0 & 0 & 0 & 1 & 0 \\
\hline Elmidae(UNK) & 0 & 0 & 0 & 0 & 0 & 0 & 0 & 0 & 0 & 0 & 0 & 0 & 0 & 0 & 0 & 0 & 0 & 0 & 0 & 0 \\
\hline Optioservus & 43 & 44 & 40 & 9 & 10 & 4 & 13 & 0 & 0 & 0 & 6 & 59 & 0 & 2 & 27 & 3 & 0 & 0 & 1 & 10 \\
\hline Promoresia & 0 & 0 & 0 & 0 & 0 & 0 & 0 & 0 & 0 & 0 & 0 & 0 & 0 & 0 & 0 & 0 & 0 & 0 & 0 & 0 \\
\hline Gonielmis & 0 & 0 & 1 & 0 & 0 & 0 & 0 & 0 & 0 & 0 & 0 & 0 & 0 & 0 & 0 & 0 & 0 & 0 & 0 & 0 \\
\hline Oulimnius & 0 & 1 & 1 & 0 & 0 & 1 & 2 & 0 & 0 & 0 & 0 & 4 & 0 & 0 & 4 & 0 & 0 & 0 & 2 & 2 \\
\hline Ancyronyx & 0 & 0 & 0 & 0 & 0 & 0 & 0 & 0 & 0 & 0 & 0 & 0 & 0 & 0 & 0 & 0 & 0 & 0 & 0 & 0 \\
\hline Microcylloepus & 0 & 0 & 0 & 0 & 0 & 0 & 0 & 0 & 0 & 0 & 0 & 0 & 0 & 0 & 0 & 0 & 0 & 0 & 0 & 0 \\
\hline Macronychus & 0 & 0 & 0 & 0 & 0 & 0 & 0 & 0 & 0 & 0 & 0 & 0 & 0 & 0 & 0 & 0 & 0 & 0 & 0 & 0 \\
\hline Stenelmis & 26 & 14 & 3 & 6 & 3 & 0 & 11 & 0 & 0 & 0 & 0 & 1 & 1 & 0 & 0 & 0 & 0 & 0 & 0 & 0 \\
\hline Dubiraphia & 0 & 0 & 0 & 0 & 0 & 0 & 0 & 0 & 0 & 0 & 0 & 0 & 0 & 0 & 0 & 0 & 0 & 0 & 0 & 0 \\
\hline Psephenidae(UNK) & 0 & 0 & 0 & 0 & 0 & 0 & 0 & 0 & 0 & 0 & 0 & 0 & 0 & 0 & 0 & 0 & 0 & 0 & 0 & 0 \\
\hline Ectopria & 0 & 0 & 0 & 0 & 0 & 0 & 0 & 0 & 0 & 0 & 0 & 0 & 0 & 0 & 2 & 0 & 0 & 0 & 0 & 0 \\
\hline Psephenus & 0 & 0 & 0 & 0 & 0 & 0 & 0 & 0 & 0 & 0 & 1 & 2 & 0 & 0 & 2 & 0 & 0 & 0 & 0 & 0 \\
\hline Dicranopselaphus & 0 & 0 & 0 & 0 & 0 & 0 & 0 & 0 & 0 & 0 & 0 & 0 & 0 & 0 & 0 & 0 & 0 & 0 & 0 & 0 \\
\hline Donacia & 0 & 0 & 0 & 0 & 0 & 0 & 0 & 0 & 0 & 0 & 0 & 0 & 0 & 0 & 0 & 0 & 0 & 0 & 0 & 0 \\
\hline Pyrrhalta & 0 & 0 & 0 & 0 & 0 & 0 & 0 & 0 & 0 & 0 & 0 & 0 & 0 & 0 & 0 & 0 & 0 & 0 & 0 & 0 \\
\hline Hydrothassa & 0 & 0 & 0 & 0 & 0 & 0 & 0 & 0 & 0 & 0 & 0 & 0 & 0 & 0 & 0 & 0 & 0 & 0 & 0 & 0 \\
\hline Disonycha & 0 & 0 & 0 & 0 & 0 & 0 & 0 & 0 & 0 & 0 & 0 & 0 & 0 & 0 & 0 & 0 & 0 & 0 & 0 & 0 \\
\hline
\end{tabular}




\begin{tabular}{|c|c|c|c|c|c|c|c|c|c|c|c|c|c|c|c|c|c|c|c|c|}
\hline Anchytarsus & 0 & 0 & 0 & 0 & 0 & 1 & 0 & 0 & 0 & 0 & 0 & 0 & 0 & 0 & 0 & 0 & 0 & 0 & 0 & 0 \\
\hline Curculionidae(UNK) & 0 & 0 & 0 & 0 & 0 & 0 & 0 & 0 & 0 & 0 & 0 & 0 & 0 & 0 & 0 & 0 & 0 & 0 & 0 & 0 \\
\hline Steremnius & 0 & 0 & 0 & 0 & 0 & 0 & 0 & 0 & 0 & 0 & 0 & 0 & 0 & 0 & 0 & 0 & 0 & 0 & 0 & 0 \\
\hline Dytiscidae(UNK) & 0 & 0 & 0 & 0 & 0 & 1 & 0 & 0 & 0 & 0 & 0 & 0 & 0 & 0 & 0 & 0 & 0 & 0 & 0 & 0 \\
\hline Celina & 0 & 0 & 0 & 0 & 0 & 0 & 0 & 0 & 0 & 0 & 0 & 0 & 0 & 0 & 0 & 0 & 0 & 0 & 0 & 0 \\
\hline Agabus & 0 & 0 & 0 & 0 & 0 & 0 & 0 & 0 & 0 & 0 & 0 & 0 & 0 & 0 & 0 & 0 & 0 & 0 & 0 & 0 \\
\hline Hydrovatus & 0 & 0 & 0 & 0 & 0 & 0 & 0 & 0 & 0 & 0 & 0 & 0 & 0 & 0 & 0 & 0 & 0 & 0 & 0 & 0 \\
\hline Staphylinidae(UNK) & 0 & 0 & 0 & 0 & 0 & 0 & 0 & 0 & 0 & 0 & 0 & 0 & 0 & 0 & 0 & 0 & 0 & 0 & 0 & 0 \\
\hline Peltodytes & 0 & 0 & 0 & 0 & 0 & 0 & 0 & 0 & 0 & 0 & 0 & 0 & 0 & 0 & 0 & 0 & 0 & 0 & 0 & 0 \\
\hline Carabidae(UNK) & 0 & 0 & 0 & 0 & 0 & 0 & 0 & 0 & 0 & 0 & 0 & 0 & 0 & 0 & 0 & 0 & 0 & 0 & 0 & 0 \\
\hline Hydrophilidae(UNK) & 0 & 0 & 0 & 0 & 0 & 0 & 0 & 0 & 0 & 0 & 0 & 0 & 0 & 0 & 0 & 0 & 0 & 0 & 0 & 0 \\
\hline Hydrochus & 0 & 0 & 0 & 0 & 0 & 0 & 0 & 0 & 0 & 0 & 0 & 0 & 0 & 0 & 0 & 0 & 0 & 0 & 0 & 0 \\
\hline Hydrophilus & 0 & 0 & 0 & 0 & 0 & 0 & 0 & 0 & 0 & 0 & 0 & 0 & 0 & 0 & 0 & 0 & 0 & 0 & 0 & 0 \\
\hline Crenitis & 0 & 0 & 0 & 0 & 0 & 0 & 0 & 0 & 0 & 0 & 0 & 0 & 0 & 0 & 0 & 0 & 0 & 0 & 0 & 0 \\
\hline Tropisternus & 0 & 0 & 0 & 0 & 0 & 0 & 0 & 0 & 0 & 0 & 0 & 0 & 0 & 0 & 0 & 0 & 0 & 0 & 0 & 0 \\
\hline Hydrobius & 0 & 0 & 0 & 0 & 0 & 0 & 0 & 0 & 0 & 0 & 0 & 0 & 0 & 0 & 0 & 0 & 0 & 0 & 0 & 0 \\
\hline Laccobius & 0 & 0 & 0 & 0 & 0 & 0 & 0 & 0 & 0 & 0 & 0 & 0 & 0 & 0 & 0 & 0 & 0 & 0 & 0 & 0 \\
\hline Berosus & 0 & 0 & 0 & 0 & 0 & 0 & 0 & 0 & 0 & 0 & 0 & 0 & 0 & 0 & 0 & 0 & 0 & 0 & 0 & 0 \\
\hline Georyssidae & 0 & 0 & 0 & 0 & 0 & 0 & 0 & 0 & 0 & 0 & 0 & 0 & 0 & 0 & 0 & 0 & 0 & 0 & 0 & 0 \\
\hline Helichus & 0 & 0 & 0 & 0 & 0 & 0 & 0 & 0 & 0 & 0 & 0 & 0 & 0 & 0 & 0 & 0 & 0 & 0 & 0 & 0 \\
\hline Dineutus & 0 & 0 & 0 & 0 & 0 & 0 & 0 & 0 & 0 & 0 & 0 & 0 & 0 & 0 & 0 & 0 & 0 & 0 & 0 & 0 \\
\hline Tenebrionidae & 0 & 0 & 0 & 0 & 0 & 0 & 0 & 0 & 0 & 0 & 0 & 0 & 0 & 0 & 0 & 0 & 0 & 0 & 0 & 0 \\
\hline Helophoridae & 0 & 0 & 0 & 0 & 0 & 0 & 0 & 0 & 0 & 0 & 0 & 0 & 0 & 0 & 0 & 0 & 0 & 0 & 0 & 0 \\
\hline Noteridae(UNK) & 0 & 0 & 0 & 0 & 0 & 0 & 0 & 0 & 0 & 0 & 0 & 0 & 0 & 0 & 0 & 0 & 0 & 0 & 0 & 0 \\
\hline Lutrochus & 0 & 0 & 0 & 0 & 0 & 0 & 0 & 0 & 0 & 0 & 0 & 0 & 0 & 0 & 0 & 0 & 0 & 0 & 0 & 0 \\
\hline Unknown Beetle & 0 & 0 & 0 & 0 & 0 & 0 & 0 & 0 & 0 & 0 & 0 & 0 & 0 & 0 & 0 & 0 & 0 & 0 & 0 & 0 \\
\hline Nigronia & 0 & 0 & 0 & 2 & 0 & 1 & 0 & 0 & 0 & 3 & 1 & 0 & 0 & 0 & 0 & 1 & 0 & 1 & 0 & 1 \\
\hline Corydalus & 0 & 0 & 0 & 0 & 0 & 0 & 0 & 0 & 0 & 0 & 0 & 0 & 0 & 0 & 0 & 0 & 0 & 0 & 0 & 0 \\
\hline Sialis & 0 & 0 & 0 & 0 & 0 & 0 & 0 & 3 & 3 & 0 & 1 & 0 & 0 & 0 & 0 & 0 & 0 & 0 & 1 & 0 \\
\hline Crambus & 0 & 0 & 0 & 0 & 0 & 0 & 0 & 0 & 0 & 0 & 0 & 0 & 0 & 0 & 0 & 0 & 0 & 0 & 0 & 0 \\
\hline Pyralidae(UNK) & 0 & 0 & 0 & 0 & 0 & 0 & 0 & 0 & 0 & 0 & 0 & 0 & 0 & 0 & 0 & 0 & 0 & 0 & 0 & 0 \\
\hline Cossidae & 0 & 0 & 0 & 0 & 0 & 0 & 0 & 0 & 0 & 0 & 0 & 0 & 0 & 0 & 0 & 0 & 0 & 0 & 0 & 0 \\
\hline Simyra & 0 & 0 & 0 & 0 & 0 & 0 & 0 & 0 & 0 & 0 & 0 & 0 & 0 & 0 & 0 & 0 & 0 & 0 & 0 & 0 \\
\hline
\end{tabular}




\begin{tabular}{|c|c|c|c|c|c|c|c|c|c|c|c|c|c|c|c|c|c|c|c|c|}
\hline Tortricidae(UNK) & 0 & 0 & 0 & 0 & 0 & 0 & 0 & 0 & 0 & 0 & 0 & 0 & 0 & 0 & 0 & 0 & 0 & 0 & 0 & 0 \\
\hline UNK & 0 & 0 & 0 & 0 & 0 & 0 & 0 & 0 & 0 & 0 & 0 & 0 & 0 & 0 & 0 & 0 & 0 & 0 & 0 & 0 \\
\hline Hemiptera (UNK) & 0 & 0 & 0 & 0 & 0 & 0 & 0 & 0 & 0 & 0 & 0 & 0 & 0 & 0 & 0 & 0 & 0 & 0 & 0 & 0 \\
\hline Corixidae & 0 & 0 & 0 & 0 & 0 & 0 & 0 & 0 & 0 & 0 & 0 & 0 & 0 & 0 & 0 & 0 & 0 & 0 & 0 & 0 \\
\hline UNK (Gerridae) & 0 & 0 & 0 & 0 & 0 & 0 & 0 & 0 & 0 & 0 & 0 & 0 & 1 & 0 & 0 & 0 & 0 & 0 & 0 & 0 \\
\hline Trepobates & 0 & 0 & 0 & 0 & 0 & 0 & 0 & 0 & 0 & 0 & 0 & 0 & 0 & 0 & 0 & 0 & 0 & 0 & 0 & 0 \\
\hline Saldidae & 0 & 0 & 0 & 0 & 0 & 0 & 0 & 0 & 0 & 0 & 0 & 0 & 0 & 0 & 0 & 0 & 0 & 0 & 0 & 0 \\
\hline Veliidae (UNK) & 0 & 0 & 0 & 0 & 0 & 0 & 0 & 0 & 0 & 0 & 0 & 0 & 0 & 0 & 0 & 0 & 0 & 0 & 0 & 0 \\
\hline Rhagovelia & 0 & 0 & 0 & 0 & 0 & 0 & 0 & 0 & 0 & 0 & 0 & 0 & 0 & 0 & 0 & 0 & 0 & 0 & 0 & 0 \\
\hline Microvelia & 0 & 0 & 0 & 0 & 0 & 0 & 0 & 0 & 0 & 0 & 0 & 0 & 0 & 0 & 0 & 0 & 0 & 0 & 0 & 0 \\
\hline Mesovelia & 0 & 0 & 0 & 0 & 0 & 0 & 0 & 0 & 0 & 0 & 0 & 0 & 0 & 0 & 0 & 0 & 0 & 0 & 0 & 0 \\
\hline Hebrus & 0 & 0 & 0 & 0 & 0 & 0 & 0 & 0 & 0 & 0 & 0 & 0 & 0 & 0 & 0 & 0 & 0 & 0 & 0 & 0 \\
\hline Merragata & 0 & 0 & 0 & 0 & 0 & 0 & 0 & 0 & 0 & 0 & 0 & 0 & 0 & 0 & 0 & 0 & 0 & 0 & 0 & 0 \\
\hline Chironomidae & 14 & 27 & 30 & 12 & 14 & 22 & 49 & 17 & 9 & 44 & 100 & 28 & 150 & 74 & 41 & 75 & 182 & 22 & 23 & 73 \\
\hline Tipulidae(UNK) & 0 & 0 & 0 & 0 & 0 & 0 & 0 & 0 & 0 & 0 & 0 & 0 & 0 & 0 & 0 & 0 & 0 & 0 & 0 & 0 \\
\hline Antocha & 0 & 0 & 0 & 0 & 0 & 0 & 10 & 0 & 0 & 0 & 0 & 0 & 0 & 0 & 0 & 0 & 0 & 0 & 0 & 0 \\
\hline Prionocera & 0 & 0 & 0 & 0 & 0 & 0 & 0 & 0 & 0 & 0 & 0 & 0 & 0 & 0 & 0 & 0 & 0 & 0 & 0 & 0 \\
\hline Tipula & 0 & 0 & 0 & 1 & 1 & 0 & 0 & 0 & 0 & 0 & 2 & 0 & 0 & 1 & 12 & 1 & 0 & 0 & 0 & 0 \\
\hline Hexatoma & 0 & 0 & 0 & 1 & 0 & 0 & 1 & 0 & 0 & 0 & 2 & 1 & 0 & 0 & 0 & 0 & 0 & 0 & 0 & 1 \\
\hline Dicranota & 0 & 0 & 0 & 0 & 0 & 0 & 1 & 0 & 0 & 0 & 1 & 0 & 0 & 1 & 0 & 0 & 0 & 0 & 1 & 0 \\
\hline Rhabdomastix & 0 & 0 & 0 & 0 & 0 & 0 & 0 & 0 & 0 & 0 & 0 & 0 & 0 & 0 & 0 & 0 & 0 & 0 & 0 & 0 \\
\hline Molophilus & 0 & 0 & 0 & 0 & 0 & 0 & 0 & 0 & 0 & 0 & 0 & 0 & 0 & 0 & 0 & 0 & 0 & 0 & 0 & 0 \\
\hline Limnophila & 0 & 0 & 0 & 0 & 0 & 0 & 0 & 0 & 0 & 0 & 0 & 0 & 0 & 1 & 0 & 6 & 0 & 0 & 2 & 0 \\
\hline Pilaria & 0 & 0 & 0 & 0 & 0 & 0 & 0 & 0 & 0 & 0 & 0 & 0 & 0 & 0 & 0 & 0 & 0 & 0 & 0 & 0 \\
\hline Leptotarsus & 0 & 0 & 0 & 0 & 0 & 0 & 0 & 0 & 0 & 0 & 0 & 0 & 0 & 0 & 0 & 0 & 0 & 0 & 0 & 0 \\
\hline Cryptolabis & 0 & 0 & 0 & 0 & 0 & 0 & 0 & 0 & 0 & 0 & 0 & 0 & 0 & 0 & 0 & 0 & 0 & 0 & 0 & 0 \\
\hline Pseudolimnophila & 0 & 0 & 0 & 0 & 0 & 0 & 0 & 0 & 0 & 0 & 0 & 0 & 0 & 0 & 0 & 0 & 0 & 0 & 0 & 0 \\
\hline Pedicia & 0 & 0 & 0 & 0 & 0 & 0 & 0 & 0 & 0 & 0 & 0 & 0 & 0 & 0 & 0 & 0 & 0 & 0 & 0 & 0 \\
\hline Brachypremna & 0 & 0 & 0 & 0 & 0 & 0 & 0 & 0 & 0 & 0 & 0 & 0 & 0 & 0 & 0 & 0 & 0 & 0 & 0 & 0 \\
\hline Erioptera & 0 & 0 & 0 & 0 & 0 & 0 & 0 & 0 & 0 & 0 & 0 & 0 & 0 & 0 & 0 & 0 & 0 & 0 & 0 & 1 \\
\hline Limonia & 0 & 0 & 0 & 0 & 0 & 0 & 0 & 0 & 0 & 0 & 0 & 0 & 0 & 0 & 0 & 0 & 0 & 0 & 0 & 0 \\
\hline Tabanus & 0 & 0 & 0 & 0 & 0 & 0 & 0 & 0 & 0 & 0 & 0 & 0 & 0 & 0 & 0 & 0 & 0 & 0 & 0 & 0 \\
\hline Chrysops & 0 & 0 & 0 & 0 & 0 & 0 & 0 & 0 & 0 & 0 & 0 & 0 & 0 & 0 & 0 & 0 & 0 & 0 & 0 & 0 \\
\hline
\end{tabular}




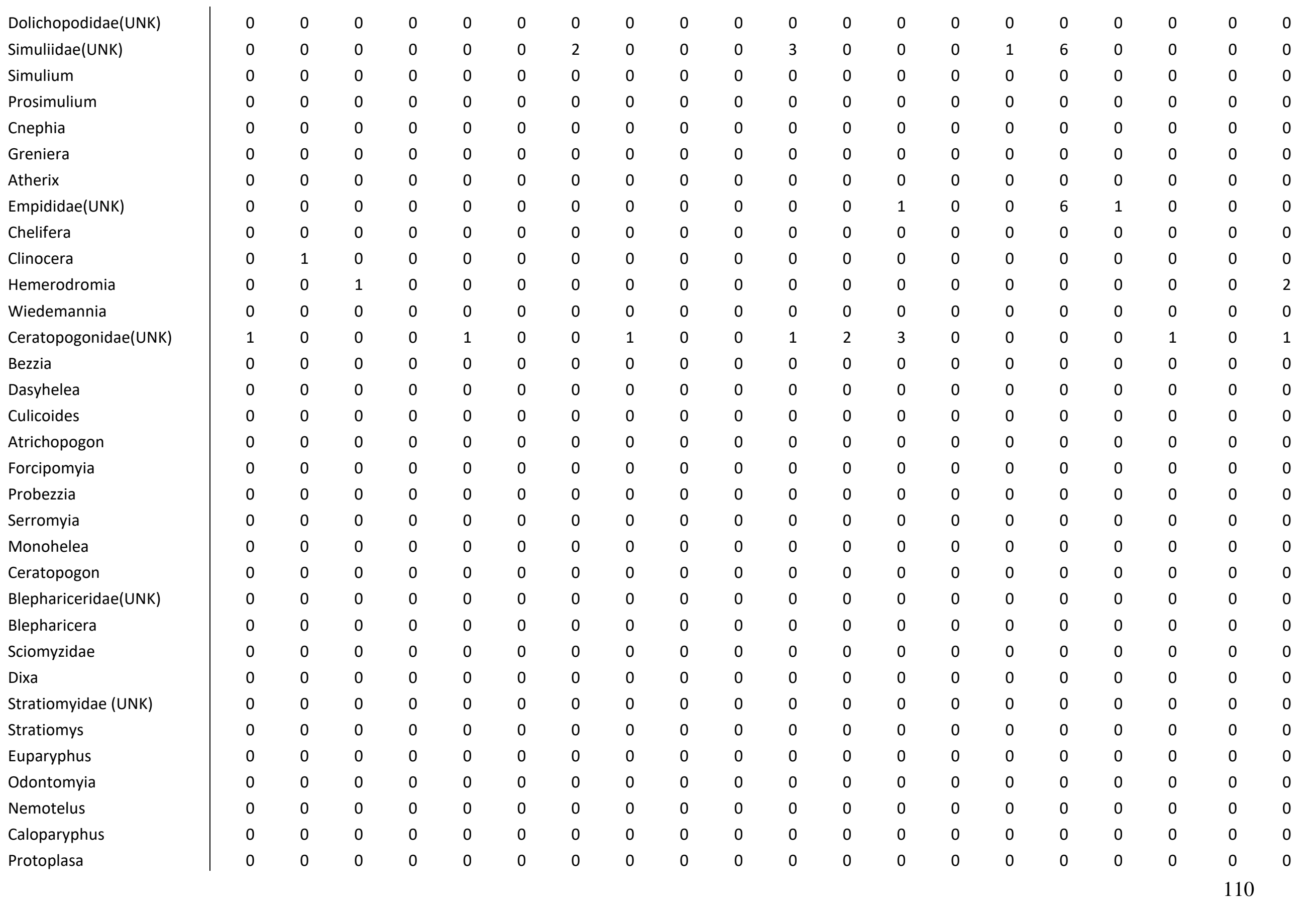




\begin{tabular}{|c|c|c|c|c|c|c|c|c|c|c|c|c|c|c|c|c|c|c|c|c|}
\hline Muscidae(UNK) & 0 & 0 & 0 & 0 & 0 & 0 & 0 & 0 & 0 & 0 & 0 & 0 & 0 & 0 & 0 & 0 & 0 & 0 & 0 & 0 \\
\hline Limnophora & 0 & 0 & 0 & 0 & 0 & 0 & 0 & 0 & 0 & 0 & 0 & 0 & 0 & 0 & 0 & 0 & 0 & 0 & 0 & 0 \\
\hline Ephydridae(UNK) & 0 & 0 & 0 & 0 & 0 & 0 & 0 & 0 & 0 & 0 & 0 & 0 & 0 & 0 & 0 & 0 & 0 & 0 & 0 & 0 \\
\hline Parydra & 0 & 0 & 0 & 0 & 0 & 0 & 0 & 0 & 0 & 0 & 0 & 0 & 0 & 0 & 0 & 0 & 0 & 0 & 0 & 0 \\
\hline Thaumaleidae(UNK) & 0 & 0 & 0 & 0 & 0 & 0 & 0 & 0 & 0 & 0 & 0 & 0 & 0 & 0 & 0 & 0 & 0 & 0 & 0 & 0 \\
\hline Psychodidae(UNK) & 0 & 0 & 0 & 0 & 0 & 0 & 0 & 0 & 0 & 0 & 0 & 0 & 0 & 0 & 0 & 0 & 0 & 0 & 0 & 0 \\
\hline Pericoma & 0 & 0 & 0 & 0 & 0 & 0 & 0 & 0 & 0 & 0 & 0 & 0 & 0 & 0 & 0 & 0 & 0 & 0 & 0 & 0 \\
\hline Psychoda & 0 & 0 & 0 & 0 & 0 & 0 & 0 & 0 & 0 & 0 & 0 & 0 & 0 & 0 & 0 & 0 & 0 & 0 & 0 & 0 \\
\hline Anopheles & 0 & 0 & 0 & 0 & 0 & 0 & 0 & 0 & 0 & 0 & 0 & 0 & 0 & 0 & 0 & 0 & 0 & 0 & 0 & 0 \\
\hline Unknown Diptera & 0 & 0 & 0 & 0 & 0 & 0 & 0 & 0 & 0 & 0 & 0 & 0 & 0 & 0 & 0 & 0 & 2 & 1 & 0 & 1 \\
\hline Hydracarina & 0 & 0 & 0 & 0 & 0 & 0 & 0 & 0 & 0 & 0 & 0 & 0 & 0 & 0 & 0 & 0 & 0 & 0 & 0 & 0 \\
\hline Hygrobatoidea & 0 & 0 & 0 & 0 & 0 & 0 & 0 & 0 & 0 & 0 & 0 & 0 & 0 & 0 & 0 & 0 & 0 & 0 & 0 & 0 \\
\hline Pisauridae & 0 & 0 & 0 & 0 & 0 & 0 & 0 & 0 & 0 & 0 & 0 & 0 & 0 & 0 & 0 & 0 & 0 & 0 & 0 & 0 \\
\hline Lycosidae & 0 & 0 & 0 & 0 & 0 & 0 & 0 & 0 & 0 & 0 & 0 & 0 & 0 & 0 & 0 & 0 & 0 & 0 & 0 & 0 \\
\hline Collembola (UNK) & 1 & 1 & 1 & 0 & 0 & 0 & 0 & 0 & 0 & 0 & 1 & 0 & 0 & 0 & 0 & 0 & 0 & 1 & 2 & 0 \\
\hline Sminthuridae(UNK) & 0 & 0 & 0 & 0 & 0 & 0 & 0 & 0 & 0 & 0 & 0 & 0 & 0 & 0 & 0 & 0 & 0 & 0 & 0 & 0 \\
\hline Bourletiella & 0 & 0 & 0 & 0 & 0 & 0 & 0 & 0 & 0 & 0 & 0 & 0 & 0 & 0 & 0 & 0 & 0 & 0 & 0 & 0 \\
\hline Sminthurides & 0 & 0 & 0 & 0 & 0 & 0 & 0 & 0 & 0 & 0 & 0 & 0 & 0 & 0 & 0 & 0 & 0 & 0 & 0 & 0 \\
\hline Agrenia bidenticulata & 0 & 0 & 0 & 0 & 0 & 0 & 0 & 0 & 0 & 0 & 0 & 0 & 0 & 0 & 0 & 0 & 0 & 0 & 0 & 0 \\
\hline Hydroisotoma & 0 & 0 & 0 & 0 & 0 & 0 & 0 & 0 & 0 & 0 & 0 & 0 & 0 & 0 & 0 & 0 & 0 & 0 & 0 & 0 \\
\hline Isotomorus & 0 & 0 & 0 & 0 & 0 & 0 & 0 & 0 & 0 & 0 & 0 & 0 & 0 & 0 & 0 & 0 & 0 & 0 & 0 & 0 \\
\hline Isotomidae(UNK) & 0 & 0 & 0 & 0 & 0 & 0 & 0 & 0 & 0 & 0 & 0 & 0 & 0 & 0 & 0 & 0 & 0 & 0 & 0 & 0 \\
\hline Neanuridae & 0 & 0 & 0 & 0 & 0 & 0 & 0 & 0 & 0 & 0 & 0 & 0 & 0 & 0 & 0 & 0 & 0 & 0 & 0 & 0 \\
\hline Podura & 0 & 0 & 0 & 0 & 0 & 0 & 0 & 0 & 0 & 0 & 0 & 0 & 0 & 0 & 0 & 0 & 0 & 0 & 0 & 0 \\
\hline Poduridae(UNK) & 0 & 0 & 0 & 0 & 0 & 0 & 0 & 0 & 0 & 0 & 0 & 0 & 0 & 0 & 0 & 0 & 0 & 0 & 0 & 0 \\
\hline UNK (Copepoda) & 0 & 0 & 0 & 0 & 0 & 0 & 0 & 0 & 0 & 0 & 0 & 0 & 0 & 0 & 0 & 0 & 0 & 0 & 0 & 0 \\
\hline Cyclopoida & 0 & 0 & 0 & 0 & 0 & 0 & 0 & 0 & 0 & 0 & 0 & 0 & 0 & 0 & 0 & 0 & 0 & 0 & 0 & 0 \\
\hline Daphnia & 0 & 0 & 0 & 0 & 0 & 0 & 0 & 0 & 0 & 0 & 0 & 0 & 0 & 0 & 0 & 0 & 0 & 0 & 0 & 0 \\
\hline
\end{tabular}

